\title{
TRANSNATIONAL CORPORATIONS
}

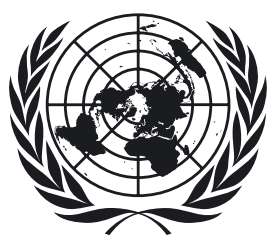

United Nations

New York and Geneva, 2015

United Nations Conference on Trade and Development

Division on Investment and Enterprise 


\title{
Editorial statement
}

Transnational Corporations (formerly The CTC Reporter) is a refereed journal published three times a year by UNCTAD. In the past, the Programme on Transnational Corporations was carried out by the United Nations Centre on Transnational Corporations (1975-1992) and by the Transnational Corporations and Management Division of the United Nations Department of Economic and Social Development (1992-1993). The basic objective of this journal is to publish articles and research notes that provide insights into the economic, legal, social and cultural impacts of transnational corporations in an increasingly global economy and the policy implications that arise therefrom. It focuses especially on political and economic issues related to transnational corporations. In addition, Transnational Corporations features book reviews. The journal welcomes contributions from the academic community, policymakers and staff members of research institutions and international organizations. Guidelines for contributors are given at the end of this issue.

\author{
Editor: James Zhan \\ Deputy Editor: Hafiz Mirza \\ Managing Editor: Shin Ohinata \\ Production Manager: Tess Ventura \\ Home page: http://www.unctad.org/TNC
}

\section{Subscriptions}

A subscription to Transnational Corporations for one year is US\$45 (single issues are US\$20). See p. 107 for details of how to subscribe, or contact any distributor of United Nations publications. United Nations, Sales Section, Room DC2-853, 2 UN Plaza, New York, NY 10017, United States - tel.: 1212963 3552; fax: 1212963 3062; e-mail: publications@un.org; or Palais des Nations, 1211 Geneva 10, Switzerland tel.: 4122917 1234; fax: 4122917 0123; e-mail: unpubli@unog.ch.

\section{Note}

The designations employed and the presentation of the material do not imply the expression of any opinion on the part of the United Nations concerning the legal status of any country, territory, city or area, or of authorities or concerning the delimination of its frontiers or boundaries.

Material in this publication may be freely quoted or printed, but acknowledgement is requested, together with a copy of the publication containing the quotation or reprint to be sent to the UNCTAD secretariat.

This publication has been reproduced without formal editing.

Unless stated otherwise, all references to dollars (\$) are to United States dollars.

ISBN 978-92-1-112886-4

e-ISBN 978-92-1-057192-0

ISSN 1014-9562

Copyright United Nations, 2015

All rights reserved

Printed in Switzerland 


\section{Board of Advisers}

\section{CHAIR}

Terutomo Ozawa, Professor of Economics, Colorado State University, Fort Collins, Colorado, United States

\section{MEMBERS}

V.N. Balasubramanyam, Professor of Development Economics, Lancaster University, United Kingdom

Edward K.Y. Chen, Former President, Lingnan University, Hong Kong, China

Farok J. Contractor, Professor of Management and Global Business, Graduate School of Management, Rutgers University, Newark, New Jersey, United States

Xian Guoming, Professor of Economics and International Business, Director, Center for Transnational Corporation Studies, Dean, Teda College of Nankai University, Tianjin, China

Kamal Hossain, Senior Advocate, Supreme Court of Bangladesh, Bangladesh

Celso Lafer, Professor, University of Săo Paulo, Brazil

James R. Markusen, Professor of Economics, University of Colorado at Boulder, Colorado, United States

Theodore H. Moran, Karl F. Landegger Professor, and Director, Program in International Business Diplomacy, School of Foreign Service, Georgetown University, Washington, D.C., United States

Sylvia Ostry, Distinguished Research Fellow and China/WTO Project Chair, Centre for International Studies, University of Toronto, Toronto, Canada

Tagi Sagafi-nejad, Radcliffe Killam Distinguished Professor of International Business; Director, Center for the Study of Western Hemispheric Trade; Director, International Trade Institute and Editor, International Trade Journal, The A. R. Sanchez, Jr., School of Business, Texas A\&M International University, Texas, United States

Mihály Simai, Professor Emeritus, Institute for World Economics, Budapest, Hungary

Osvaldo Sunkel, Professor and Director, Center for Public Policy Analysis, University of Chile, Santiago, Chile

Marjan Svetlicic, Head, Centre of International Relations, Faculty of Social Sciences, University of Ljubljana, Slovenia

Daniel Van den Bulcke, Professor of International Management and Development, University of Antwerp, Belgium 


\section{Transnational Corporations}

Volume 22, Number 3, December 2013

\section{Contents}

\section{INTRODUCTION}

Victor Z. Chen

Emerging market multinationals

1

and Lise Johnson and social responsibility: an institutional pressure perspective

\section{ARTICLES}

Davide Fiaschi, Elisa Giuliani and Federica Nieri

Kevin May

Sara L. Seck
BRIC companies in search of 5 legitimacy: an empirical analysis of the use of different CSR instruments

Chinese agricultural overseas 43 investment: trends, policies and CSR

Emerging-Market Multinationals, 75 Human Rights, and Sustainable Development: Lessons from the Canadian Experience 


\section{Emerging market MNEs and social responsibility: an institutional pressure perspective}

\section{Victor Z. Chen and Lise Johnson*}

Emerging market multinational enterprises (EMNEs) represent a rising share in global outward foreign direct investment (FDI), growing from only 10 per cent in 2000 to 40 per cent in 2013 (UNCTAD, 2014). Like their developed market counterparts, these EMNEs can have important and potentially transformative impacts on their home and host countries, raising crucial questions regarding the appropriate law and policy frameworks that should govern their activities. To answer these questions, however, requires deeper and more comprehensive understanding of these new actors and their implications. To date, little is known about the impacts EMNEs have on issues related to sustainable development at home and abroad (Gugler and Shi, 2009), and the factors that are shaping those impacts. While there is a growing body of literature focusing on EMNEs (for reviews, see Gammeltoft, Barnard, and Madhok, 2010; Luo and Tung, 2007; Ramamurti, 2012), many issues about these firms' development effects remain underexplored. It is for this reason that we organized this special issue. ${ }^{1}$ The three articles that are part of this collection highlight the most salient and pressing issues regarding EMNEs: In what sectors and locations are EMNEs investing, and what impacts might these investments have on sustainable development? Are EMNEs dedicating efforts to corporate social responsibility (CSR) and if so, through what types of activities? What is driving the firms' engagement with CSR? And how can and should institutions in home countries, host countries, and

${ }^{*}$ Victor Z. Chen is an Assistant Professor of International Management at the Belk College of Business, University of North Carolina at Charlotte, and Emerging-Market Global Players (EMGP) Global Coordinator and Editor at Columbia Center on Sustainable Investment, Columbia University. His E-mail address is EMGP.Editor@gmail.com. Lise Johnson is a Legal Researcher and the Head of Investment Law and Policy at Columbia Center on Sustainable Investment, Columbia University. Her E-mail address is ljj2107@columbia.edu.

${ }^{1}$ The contributions were received from an open call for papers on EMNEs and sustainable development. In early 2013, we received 15 high quality submissions from scholars and policy researchers based in more than ten countries. After the first round of peer reviews, we have invited four papers in fall 2013 for revision and resubmission. After two more rounds of peer reviews, three of these four papers were finally selected in summer 2014 for publication in this special issue for their topic novelty, rigorous research design, depth of analysis, and policy relevance. 
on the international plane shape corporate conduct and development outcomes?

In their article, "BRIC companies seeking legitimacy through corporate social responsibility", Davide Fiaschi, Elisa Guiliania, and Federica Nieri (University of Pisa, Italy), analyze firm-level data on the types of CSR activities in which EMNEs engage and the drivers - in home and host countries - behind such engagement. Their research emphasizes the importance of industry leaders and host country institutions in driving engagement with CSR, while highlighting the unanswered question about whether more visible or "explicit" engagement on CSR issues actually translates into meaningful behavioral changes.

Kevin May's (Oxfam Hong Kong, China) article, "Chinese agricultural overseas investment: trends, policies and CSR", delves into issues surrounding Chinese outward investment in agriculture. He highlights the opportunities and challenges such investment poses for poverty reduction, inclusive growth, and environmental protection in host countries; the amount of Chinese investment as compared to other international investment; the steps taken by Chinese government officials and entities to promote "win-win" outcomes; apparent takeup of these initiatives by investing firms; and outstanding issues and questions. May's findings suggest that existing Chinese policies are inadequate to ensure Chinese foreign direct investment in agriculture contributes to sustainable development in host countries. Although broad principles supporting CSR are repeatedly reflected in many policy documents, both the details on specific actions to be taken, and mechanisms for enforcement, are limited. Further reforms are therefore needed to ensure effective implementation of high-level policies on CSR.

Following May's focus on China as a government increasingly seeking to influence the conduct of its outward investors, Sara L. Seck (Western University, Canada) examines the roles and responsibilities of home countries more generally, and investigates the extent to which emerging market countries and EMNEs have been engaged in efforts to establish and enforce international norms on MNE conduct. Her article, "Emerging-market multinationals, human rights, and sustainable development: lessons from the Canadian experience", argues that while 
many initiatives targeting MNEs - e.g., the IFC Performance Standards, the Voluntary Principles on Security and Human Rights, and the OECD Guidelines for Multinational Enterprises - have typically been launched and influenced by developed countries and their firms, emerging markets and EMNEs are increasingly playing a role; and with initiatives such as the BRICS New Development Bank, that role will continue to expand and become even more crucial for ensuring the contribution of international investment to sustainable development.

Each of these three studies is an important contribution to the discussion of whether and how institutional pressures can influence the conduct of EMNEs. Together, these articles also contribute to the emerging discussion on CSR practices in international business in two important ways. First, CSR studies have been primarily focused on traditional MNEs from developed markets (for a review, see Kolk and van Tulder, 2010). This issue usefully focuses on the current efforts, performance, and future directions of the increasingly important EMNE CSR practice. Second, the current discussion in the emerging-market CSR literature primarily focuses on the market-based solutions such as the Bottom of Pyramids (for a review, see Kolk and van Tulder, 2010) and financial market response (Mishra and Suar, 2010). This special issue, focusing on institutional and regulatory pressures, highlights the important role of host and home country policy engagement.

As EMNEs become increasingly influential in affecting patterns of economic growth, quality of life, and environmental protection, understanding their motives, practices and influences - as these three contributions do - becomes increasingly important.

\section{Reference}

* Papers in this special issue

* Fiaschi, D., Giuliani, E. and Nieri, F. (2013). "BRIC companies seeking legitimacy through corporate social responsibility", Transnational Corporations, current issue.

Gammeltoft, P., Barnard, H., and Madhok, A. (2010). "Emerging multinationals, emerging theory: Macro-and micro-level perspectives", Journal of International Management, 16(2): 95-101.

Gugler, P., and Shi, J.Y. (2009). "Corporate social responsibility for developing country multinational corporations: lost war in pertaining global competitiveness?", Journal of Business Ethics, 87(1): 3-24. 
Kolk, A. and Van Tulder, R. (2010). "International business, corporate social responsibility and sustainable development", International Business Review, 19(2): 119-125.

Luo, Y. and Tung, R.L. (2007). "International expansion of emerging market enterprises: A springboard perspective", Journal of International Business Studies, 38(4): 481498.

* May, K. (2013). "Chinese agricultural overseas investment: Trends, policies and CSR", Transnational Corporations, current issue.

Mishra, S. and Suar, D. (2010). "Does corporate social responsibility influence firm performance of Indian companies?", Journal of Business Ethics, 95(4): 571-601.

Ramamurti, R. (2012). "What is really different about emerging market multinationals?", Global Strategy Journal, 2(1): 41-47.

* Seck, S.L. (2013). "Emerging-market multinationals, human rights, and sustainable development: Lessons from Canadian experience", Transnational Corporations, current issue.

UNCTAD (2014). World Investment Report 2014: Investing in the SDGs - an Action Plan. New York and Geneva: United Nations. 


\section{BRIC companies seeking legitimacy through Corporate Social Responsibility}

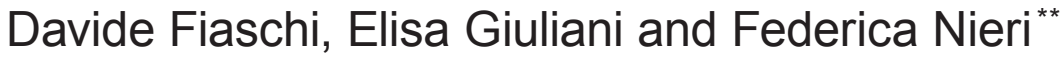

BRIC countries have generally gone through a process of liberalization and rapid economic growth that has allowed their major companies to acquire increasing weight in the global marketplace. However, they are still striving to achieve full legitimacy in the international arena. In a bid to close this legitimacy gap, BRIC firms are making efforts to align with the Environmental, Social and Governance (ESG) global norms of doing business, and recently have adopted a portfolio of Corporate Social Responsibility (CSR) initiatives. In this paper we provide a deeper exploration into the factors that relate to BRIC firms' adoption of different types of CSR initiatives - i.e. social policies (philanthropic projects favoring different stakeholders); publication of CSR reports; adoption of GRI standards; adherence to and financial support for the UN Global Compact. We carry out an empirical analysis on 60 large public BRIC companies, and find support for the idea that different kinds of CSR initiatives may be subject to different pressures and may serve different legitimization strategies.

Key words: BRIC firms, internationalization, Corporate Social Responsibility (CSR), liability of foreignness (LOF) and emergingness (LOE), mimetic isomorphism.

\section{Introduction}

Emerging markets have generally gone through a process of liberalization and rapid economic growth that has allowed their major companies to acquire increasing weight in the global marketplace (Lenssen et al., 2011). Among these emerging markets, Brazil, the Russian Federation, India and China (i.e.

* This article was accepted for publication in September 2014. The opinions expressed in this article are those of the authors and do not necessarily reflect the views of the United Nations.

** The authors are at the Department of Economics \& Management (DEM), University of Pisa, Italy. The corresponding author is Elisa Giuliani. Contact E-mail: elisagiuliani@gmail.com; giulel@ec.unipi.it . The authors thank Chiara Macchi, Claudio Cozza and Pietro Sabetta for help with data collection. Data and financial support from the EU Global Challenges (Volkswagen Foundation) and EU COST Projects are gratefully acknowledged. The usual disclaimers apply. 
the BRIC economies) have grown particularly quickly. ${ }^{1}$ In the period 2001-2010, the total population of the BRIC increased from 2,654 million to 2,880 million, while total GDP increased from $\$ 7.4$ billion to \$19.4 billion (current international \$) with an average real growth rate per year of 8.2 per cent. In 2010, the BRIC countries accounted for over a quarter of the world's land area, 42 per cent of the world's population, and 25 per cent of the world's gross national income (compared to 17 per cent in 2001) (World Development Indicators, 2013).

Despite this impressive growth, the BRIC countries are still striving to achieve full legitimacy in the international arena. Their cultural values and norms, which are some distance from those of most Western societies, have resulted in stakeholders in the West viewing the BRIC economies with a degree of suspicion. For instance, the international expansion of Chinese State-Owned Enterprises (SOEs) is often seen as predatory investment, and an expression of the investing country's or state's interest in gaining control over advanced economy strategic assets and infrastructures, which is also causing concerns related to loss of dominance in key technological capabilities (Giuliani et al., 2014). This lack of national legitimacy has repercussion on BRIC firms" own legitimacy, which is defined as "a generalized perception or assumption that the actions of a firm are desirable, proper or appropriate within some socially constructed system of norms, values, beliefs, and definitions" (Suchman, 1995: 574). These concerns include the capacity of BRIC firms to properly address environmental, social and governance (ESG) issues - the focus of this paper - given the perceived institutional weaknesses of their home countries in these areas (Madhok and Kayhani, 2012; Hawn, 2013).

In a bid to close this legitimacy gap, BRIC firms are making efforts to align with ESG global norms of doing business, and recently have adopted a portfolio of Corporate Social Responsibility (CSR) initiatives (Gugler and Shi, 2009). Besides being engaged in philanthropic initiatives and social projects, which have long historical roots in BRIC countries and are grounded on "on deep-rooted indigenous cultural traditions of philanthropy, business ethics, and community embeddedness" (Visser,

${ }^{1}$ Some ten years ago, Jim O'Neill, global economist at Goldman Sachs, proposed the term BRIC to encompass some common traits, such as size, GDP, growth expectations, and expected future dominance in the manufacturing, services and primary industries. 
2008: 481), BRIC firms have increased their commitment to the most contemporary Western conceptualizations of CSR, which for emerging markets are relatively new phenomena (UNCTAD, 2008). We refer here specifically to reporting and principle-based initiatives (see also Gilbert et al., 2011; Rasche et al., 2013). The latter include adherence to the UN Global Compact (UNGC), which is a voluntarily initiative involving firms' commitment to align their operations and strategies with ten universally accepted principles focusing on human rights, labour rights, environmental sustainability and anti-corruption (Kell, 2005; Rasche, 2009; Kell, 2013), as well as the financial support for the Foundation for the Global Compact, which, introduced in 2006, is considered as reinforcing the commitment to sustaining development of the UNGC network. ${ }^{2}$ Reporting initiatives are also on the rise among BRIC firms and refer to the issuance of CSR reports that account for and communicate firms' ESG impact to interested stakeholders, and to the adherence to international standards designed to homogenize as far as possible the structure and content of such reports. The global standard for reporting on ESG issues is the Global Reporting Initiative (GRI), which provides a standardized framework for non-financial reporting similar to the generally accepted accounting principles for financial reporting (Rasche et al., 2013).

While some recent studies have investigated BRIC and other emerging-market firms' engagement with CSR policies, research in this area is still limited. In particular, most of the existing studies about CSR in BRIC countries either take a historical and overarching perspective on CSR (e.g. Griesse, 2007; Cheung et al., 2009; Dobers and Halme, 2009; Gugler and Shi, 2009), or focus on single CSR initiatives at a time (e.g. Thomas, 2001; Chaudri and Wang, 2007; Gupta, 2007; Bo et al., 2009; Arevalo and Aravind, 2011; Gao, 2011; Preuss and Barkemeyer, 2011; Kuo et al., 2012; Amaldoss and Manohar, 2013; Marquis and Qian, 2014). Only a few studies compare adoption of different CSR initiatives and discuss their potentially diverse drivers (these include Chapple and Moon, 2005; Baskin, 2006).

In this paper we take a step ahead in this literature and explore empirically the factors that contribute to BRIC firms' adoption of

${ }^{2}$ A full description of the Foundation can be found at: http://www. globalcompactfoundation.org/. 
different types of CSR initiatives - i.e. social policies (philanthropic projects favouring different stakeholders), publication of CSR reports, adoption of GRI standards; adherence to and financial support for the UNGC. A central tenet of most existing research on the steady adoption of CSR initiatives by BRIC companies is that this is due to their growing internationalization (Gugler and Shi, 2009, see also Strike et al., 2006). Our study explores whether the institutional quality of the host countries - in terms of their degree of press and speech freedom - relates to BRIC firms' adoption of different CSR initiatives. Furthermore, we assess empirically whether the adoption of the CSR initiatives is related to home country institutional pressures - i.e. local mimetic isomorphism (e.g. imitation of the most reputable firms) à la DiMaggio and Powell (1983). In so doing, our study aims at improving our understanding of the use that BRIC companies make of CSR to overcome their Liability of Foreignness (LOF) and Emergingness (LOE) (see Section 3.1 for a definition) and gain legitimacy in international markets (Hymer, 1976; Ramachandran and Pant, 2010; Madhok and Kayhani, 2012).

To address these questions, our study relies on an original firmlevel dataset that includes information on 60 BRIC firms selected from the Forbes Global 2000 list. We carry out a regression analysis based on an unbalanced panel of firms, covering the period 2003-2010. We find that both host countries' press and speech freedom, as well as home countries' isomorphic pressures positively relate to BRIC firms' overall engagement in CSR initiatives. However, we also find support for the idea that different kinds of CSR initiatives are subject to different pressures and may thus serve different legitimization strategies. The publication of CSR reports appears higher among firms that invest in countries characterized by high press freedom, signalling that it is an instrument used to overcome firms' LOF/LOE. We find also that all kinds of reporting and principle-based initiatives are influenced by home country isomorphic pressures, but that adoption of social policies is not correlated with either host countries' level of press and speech freedom or home country's isomorphic pressures. Our research has implication for neo-institutional analyses of international business, and the CSR-related literatures.

The paper is organized as follows: section 2 is a short overview of how CSR has been understood and promoted in Brazil, the Russian Federation, India and China over time. Section 3 elaborates the 
conceptual framework for the analysis in this paper. Section 4 discusses the methodology used, and section 5 presents the results of the empirical analysis. Section 6 concludes.

\section{CSR in BRIC Countries: A Historical Overview}

The ways that corporate responsibility for society is understood, implemented and socialized within a country vary greatly, depending on the country's national business system - i.e. the political, financial, educational, labour and cultural systems, the structural features of the business sector, and the dominant corporate governance model (Matten and Moon, 2008; loannou and Serafeim, 2012). Although the BRIC countries share a similar trajectory of recent economic growth, their national business systems are very different, which explains how CSR has been conceived over time in these countries (Baskin, 2006; Dobers and Halme, 2009; Amaldoss and Manohar, 2013). In essence, in Brazil and India the commitment of firms to contribute to the social good of their surrounding society has cultural and religious roots, and both countries have increased their overall interest in CSR as a consequence of the growing globalization of their economies. In China the government has historically played (and still plays) a very central role in setting the social responsibility agenda of state-owned and private firms, while the Russian Federation appears to be the country with the weakest CSR commitment of all. Below we provide in some more details the history of CSR adoption in each of the BRIC countries.

\section{Brazil}

A focus on CSR in Brazil started with the recognition that government was frequently failing to respond to all societal needs (e.g. to address poverty and other social welfare issues), and that individual citizens as well as firms must take responsibility for addressing these needs. The concept of citizenship (cidadania) in Brazil stems from this responsibility and is considered to have Catholic roots: "the first business organization to address the area of corporate social responsibility in Brazil was ... a branch of the International Christian Union of Business Executives (UNIA-PAC), which since ... 1961 has grown into a national network ... to reactivate the Catholic tradition of charity and promote understanding of a Christian vision in business" 
(Griesse, 2007: 31). The recent history of Brazil has seen business entrepreneurs gathering to discuss the roles and responsibilities of business in society. Notable examples include the group Pensamento Nacional das Bases Empresariais (PNBE) formed in 1987; the Grupo de Institutos Fundacoes e Empresas (GIFE) formed in the mid-1980s; and the establishment in 1989 of the Asociaciao Brazilera dos Fabricantes de Brinquedos (ABRINQ) by a leading Brazilian advocate of CSR, Oded Grajew (Raufflet, 2008). More notably, in 1998 Grajew funded the Ethos Institute as an association of companies whose objective was to disseminate the practice of CSR in Brazil, and which currently has more than 1,500 associate firms. ${ }^{3}$ All these organizations created the conditions for the dissemination of a CSR mentality in Brazil, built on a long-standing tradition of philanthropy inspired by Catholic charity and compassion (Medeiros et al., 2002; Puppim de Oliveira, 2006). By means of publications and workshops, Ethos has worked actively to promote non-financial reporting by its member companies. Another groundbreaking development in Brazil was the decision taken by the main national stock exchange, the São Paulo-based Bovespa, in December 2005 to launch a corporate sustainability index, which currently includes 28 companies demonstrating best ESG practice (Vives, 2012).

The roots of Brazilian firms' commitment to CSR are not just locally driven however, and observers note that the growing internationalization of the bigger industry players has contributed to boosting CSR policies in the country: "Brazilian companies have gone international, and that's a new big pressure,[since] when you go abroad, if you prove that you are more inclusive, you get more attention" (Claudio Boechat quoted in Bevins, 2011). ${ }^{4}$ As a consequence of both international and local pressure, Brazilian companies' social responsibility practice has a degree of sophistication that is unparalleled in Latin America (Scharf, 2008)..$^{5}$ Araya (2006) finds that, while CSR reporting in Latin America is underdeveloped compared to Western standards, Brazil has made significant progress vis-à-vis other Latin American countries and a growing number of firms have achieved ISO social and environmental

3 http://fenix.ethos.org.br/ListaAssociadasPorEstado.aspx, last accessed $12^{\text {th }}$ November 2013.

http://latintrade.com/2011/05/csr-brazil\%E2\%80\%99s-csr-leaders, Last accessed $15^{\text {th }}$ November 2013.

5 http://www.americasquarterly.org/node/288, Last accessed $15^{\text {th }}$ November 2013. 
certification, joined the UN Global Compact, and adopted GRI standards in their self-reporting activities (Vives, 2012) making Brazil the third largest adopter of GRI standards after the United States and Spain in 2011.

\section{The Russian Federation}

The Russian Federation's absolutist tradition from the Tsarist to the Soviet periods constrained the rise of social movements and other civil society organizations to promote social causes and related CSR initiatives (Preuss and Barkemeyer, 2011). While the communist ideology glorified the worker and left very little room for business sector decision making (Apressyan, 1997), paternalism towards employees and other social spheres was common during the Soviet period and also during the transition to a market economy (Soboleva, 2006). Although the state-controlled economy began transition to a market-economy in the 1990s, the situation did not improve. In addition to the widespread corruption and proliferation of criminal activities, privatization of once public assets increased wealth inequality and contributed to the creation of a new class of oligarchs, who most Russians view as "usurpers of public wealth" (Kuznetsov et al., 2009: 39). This weak institutional environment was further exacerbated by the recent policy drift that has reduced press freedom, and constrained the operations of social movements and NGOs (Rosefielde and Hlouskova, 2007; Crotty, 2009). Thus, the contemporary Russian Federation does not seem to be the most favourable institutional environment for the development of bottom-up CSR movements.

However, the Russian Federation is also becoming more global, and the growing internationalization of its private and SOEs has exerted considerable global isomorphic pressure (Preuss and Barkemeyer, 2011) to adopt Western CSR standards. These demands have resulted in the promotion of a number of initiatives. For instance, in 2002 the Russian Union of Industrialists and Entrepreneurs approved a Corporate Code of Business Ethics, and many Russian corporations now have their own business ethics codes (Soboleva, 2006). Also, since 2000, the Ministry of Labour and Social Protection has sponsored the "Russian Organization of High Social Efficiency" contest, which gives companies the opportunity to demonstrate their ESG achievements (in areas such as personnel management, labour conditions and labour protection, 
development of social partnerships, promotion of healthy lifestyles, etc.). ${ }^{6}$ In 2001, the Global Compact was launched, and since then, the Russian Union of Industrialists and Entrepreneurs, jointly with UNDP, has focused its efforts on developing an active network in the Russian Federation. In 2008, the UN Secretary-General Ban Ki-moon attended the re-launch of the Global Compact Network in the country during a meeting with more than 30 top executives from Russian business although participation of Russian firms in the UN Global Compact is still limited. However, the Government appears to provide few incentives for socially responsible behaviours, and analysts consider the adoption of CSR policies to be more symbolic than substantial (Soboleva, 2006).

\section{India}

Scholars agree that CSR is not a new concept in India, since Indian businessmen traditionally were involved in solving social problems long before the term CSR became part of the management vocabulary (Arevalo and Aravind, 2011). Religion and charity have always been intertwined in India, and even before India's independence in 1947, the business sector made significant contributions to their communities - e.g. by building schools, hospitals, etc. (Arora and Puranik, 2004). Thus, India draws on a deep-rooted indigenous cultural tradition of philanthropy, business ethics, and community embeddedness (see Visser, 2008; Amaldoss and Manohar, 2013). Since independence, Indian public sector companies have engaged in various state-sponsored CSR activities, and the Government of India, along with NGOs and the media, has become an agent of change (Narwal and Sharma, 2008). Since the introduction of India's liberalization policy in 1991 and especially after 2000 when global pressures to adopt responsible business policies became stronger, CSR changed in favour of a more Westernized approach, which promotes instrumental adoption of CSR not just for reasons of benevolence but to enhance firm's profitability (Balasubramanian et al., 2005). India is considered by many to have caught up considerably with respect to Western standards. New bodies are emerging including the Corporate Roundtable on Development Strategies for the Environment and Sustainable Development - Business Council for Sustainable Development (CoRE-BCDS) of India (Amaldoss and Manohar, 2013).

\footnotetext{
${ }^{6}$ http://www.rosmintrud.ru/eng/events/12, last accessed 12 November 2013.
} 
In 2007, the Confederation of Indian Industry (CII) and the Global Compact Office signed a Memorandum of Understanding according to which the $\mathrm{Cll}$ formally strengthened its commitment to advancing the principles of the UN Global Compact - both in India and around the world. In the same year, the Indian Prime Minister asserted that:

Corporate social responsibility ... should be defined within the framework of a corporate philosophy which factors the needs of the community and the regions in which a corporate entity functions. This is part of our cultural heritage. Mahatma Gandhi called it trusteeship... I invite corporate India to be a partner in making ours a more humane and just society... We need a new Partnership for Inclusive Growth based on what I describe as a Ten Point Social Charter...first, we need to have healthy respect for your workers and invest in their welfare... (cited in Lee, 2010: 2).

Because of this, scholars believe that the norms of business philanthropy are well established in contemporary India (Chapple and Moon, 2005).

\section{China}

Historically, when Confucianism was dominant in China, business organizations were conceived as extensions of families, and responsibility for the social community (the "political family") was largely taken for granted. Zhan Buddhism and Daoism influenced business practices in traditional Chinese society, and their combination with Confucianism in the 16th to 18th centuries, induced a business culture of honesty, diligence and charity (Lin, 2010). The Cultural Revolution (1966-1976), and the subsequent progressive opening of the Chinese economy challenges this approach and has produced profound changes in the Chinese conception of CSR (Gao, 2011). In the traditional communist Chinese society, SOEs were obliged by central government to provide social services to their employees and their family members (e.g. employee protection, education, health services, etc.). These services were provided alongside production activities which were not meant to be profitable. During that period, reference to CSR was not explicit, but analysts consider SOEs' social services to be the form closest to CSR in that period. After the 1993 Corporatization Reform, which was meant to enhance SOEs' market competitiveness and instil a profit-seeking 
mentality, central government's requirement for provision of social services ceased to be mandatory, and hospitals and schools became a local government responsibility. SOEs continued to provide these social services, but central government ceased to fund those activities (Bo et al., 2009). Alongside these changes, internationalization of the Chinese economy increased - e.g. China entered the WTO in 2001 - and it was progressively more exposed to significant international scrutiny, due in no small part to the criticism directed at Chinese companies operating abroad (Lin, 2010). This moved CSR up in the government agenda, and since 2004, CSR has become a key issue in Chinese academic and policy forums.

In 2005, the Chinese President Hu Jintao proposed the concept of "Harmonious Society" as a guiding principle for policymakers and the business sector. A harmonious society was defined as a society "which gives full play to modern ideas like democracy, rule of the law, fairness, justice, vitality, stability, orderliness and harmonious coexistence between the humankind and nature" (See, 2009: 2) In Chinese Communist Party rhetoric, the ideal of a "harmonious society" came to be synonymous with modern CSR. Other state-led interventions followed. For instance, in 2006 the Company Law stated explicitly (Article 5) that "in the course of doing business, a company must comply with laws and administrative regulations, conform to social morality and business ethics, act in good faith, subject itself to the government and the public supervision, and undertake social responsibility." (Lin, 2010: 71, emphasis added).

Over that period also, the two Chinese stock exchanges (Shenzhen and Shanghai) took actions to promote CSR disclosure, and in 2008 the Shanghai Stock Exchange mandated certain listed companies (i.e. companies listed in the Shanghai Stock Exchange Corporate Governance Index, companies listed overseas, and companies in the financial sector) to issue an annual CSR report beginning in the fiscal year 2008. Another landmark intervention occurred in 2008 when the StateOwned Assets Supervision and Administration Commission of the State Council (SASAC), the Chinese SOE regulatory body, released its "Guiding Advice on Fulfilling Social Responsibility by SOEs" with the objective of stressing the exemplary role of SOEs in acting out government's CSR agenda, and outlining the principles and the implementation of CSR measures (Lin, 2010; Gao, 2011). 
To conclude, the Government of China has played (and it still does play) a very central role in promoting and shaping the country's CSR agenda, while other stakeholders seem to contribute to only a minor extent to this process (Peiyuan et al., 2007). Although most government directives are not mandatory but are rather indicative of what are considered to be important areas for corporate focus (Marquis and Qian, 2014), it is clear that government sets the boundaries to CSR issues permissible in China - e.g. greater emphasis on environmental than human rights issues.

\section{Conceptual Framework}

\subsection{Legitimacy building and the liability of foreignness and emergingness of BRIC companies: Why is CSR much needed?}

In its most profound and implicit meaning - that of business support to communities - CSR has for long been present in most traditional BRIC societies. However, the modern understanding of CSR - involving adoption of CSR reporting and adherence to internationally agreed international principles - has unarguably been associated by many scholars to the growing internationalization of BRIC countries and firms, and their need to mimic Western CSR standards (Gugler and Shi, 2009 among many others). Theoretically, this is explained by the attempts of multinational enterprises (MNEs) to overcome the Liability of Foreignness (LOF) they experience when investing abroad. The concept of LOF, which was originally introduced by international business scholars in the 1960s-1970s (e.g. Hymer, 1976), refers to the disadvantaged position of foreign firms in a host country, compared to that of its domestic firms.

LOF has various sources including foreign firms' unfamiliarity with and lack of legitimacy in the host country (Zaheer, 1995). The building of legitimacy is a socially constructed process, constrained and influenced by the information asymmetries suffered by different host countries' stakeholders (e.g. communities, clients, investors, government officials, etc.), which often make judgments based on their stereotype perceptions of the foreign investors and their home country (Kostova and Zaheer, 1999). It is accepted that BRIC MNEs investing abroad 
carry the burden of the backwardness and to an extent, illegitimacy of their home countries (Hawn, 2013). The additional disadvantage that emerging-market multinationals tend to suffer as compared to advanced-country firms' investing abroad has been defined as Liability of Emergingness (LOE) (Ramachandran and Pant, 2010; Madhok and Kayhani, 2012), and it refers to the extra burden that arises specifically from being an emerging economy firm. The weaknesses of their home countries' institutional and business systems coupled with news about the irresponsible behaviour of some of their firms (see e.g. the case of Foxconn in China, or of the scandal about milk adulterated with melamine which caused the death of several infants in China) contributes to the accumulation in the host countries of negative judgments. In essence, "there is a credibility and legitimacy deficit in the eyes of host country stakeholders, who became even more circumspect due to inefficient or missing knowledge of foreign emerging market multinational firms, their quality and safety standards, and the like" (Madhok and Kayhani, 2012: 31).

Firms can overcome LOF/LOE in different ways. One is by exploiting firm-specific advantages (e.g. strong brand, excellent technological capabilities, scale and scope economies, etc.) to outweigh the costs associated with being a foreign firm. Another is by attending to the demands of the host environment via different forms of isomorphism (DiMaggio and Powell, 1983; Zaheer, 1995), which in essence means reducing the institutional distance between home and host country's requirements. BRIC MNEs may not be in a position to count on firm-specific advantages, not least because for many of these firms' investment abroad is aimed at acquiring, rather than exploiting, such advantages (Matthews, 2006; Rugman, 2009; Giuliani et al., 2014). Therefore, scholars have advanced the idea that BRIC firms try to build legitimacy by complying with international CSR standards (Gugler and Shi, 2009; Campbell et al., 2012).

For instance, reporting initiatives may serve BRIC companies' urgent need to demonstrate greater transparency in their ESG conduct, and to therefore communicate openly and clearly how their ethical values, as well as projects in favour of the environment and society, are aligned with what most Western stakeholders would regard as appropriate and desirable. Similarly, principle-based initiatives may fulfil BRIC companies' necessity to show off their commitment to 
internationally-agreed codes of conduct, in areas such as human and labour rights, environment and corruption, and to demonstrate that, after all, their ethical values and principles are not dissimilar to those of Western societies.

While commitment to CSR may serve the general goal of reducing the legitimacy gap BRIC companies have with international stakeholders, there are different ways in which this may be undertaken. BRIC firms may privilege certain CSR initiatives to others (e.g. principle vs. reporting initiatives), as certain initiatives may be subject to or react to different types of institutional pressures, as compared to others. As anticipated earlier, we explore here the role played by two types of pressures: the institutional characteristics - defined on the basis of their press and speech freedom - of the host countries where BRIC companies undertake foreign investments, and the pressures coming from within their own home country, where mimetic isomorphism (DiMaggio and Powell, 1983) may play a role in stimulating the adoption of certain CSR initiatives. This is elaborated below.

\subsection{Host countries' press and speech freedom}

Extant literature has so far claimed that the international expansion of BRIC companies has pushed them to align with certain international CSR standards, and therefore that these firms are subject to significant international isomorphic pressures. However, earlier research has also pointed at the fact that internationalizing firms do encounter different types of institutional pressures depending on the institutional, cultural, geographic and economic features of host countries, which vary widely across the world, with some countries being more demanding than others in terms of expectations about the ESG behaviour of investing firms (Kostova et al., 2008; Campbell, 2012). In such a varying context, we expect firms not to conform to international isomorphic pressures per se, but rather to react to their host countries' institutional differences and adjust their CSR accordingly. Else said, BRIC firms may use different CSR initiatives instrumentally and strategically with the purpose of achieving their objective of obtaining a license to operate in a particular context.

While some studies have looked at how host-home country institutional distance influences multinational firms' CSR strategies, 
few studies have looked at how host country characteristics relate to firms' choice on CSR initiatives. An exception is Brammer et al. (2009), whose work on United Kingdom firms investing abroad shows that firms investing in countries with poor political and civil rights will increase their charitable donations, because investment in such countries is likely to induce greater stakeholder pressure and closer scrutiny of the ethicality of the firm's strategy and whether the firm is investing to take advantage of such weaknesses. This study demonstrates that firms may adjust their CSR strategies to specific contexts.

As opposed to Brammer et al. (2009), in this paper we elaborate a different hypothesis, by stating that countries with limited press and speech freedom (which constitute a subcategory of the broader category of civil and political rights) are likely to reduce BRIC firms' commitments into certain CSR activities, particularly reporting CSR initiatives. We base our argument on two considerations. First, when BRIC firms invest in countries that strongly uphold both press and speech freedoms, they will need a more sophisticated legitimacy building strategy compared to investments in countries with a poor record of freedoms of speech and press. Press freedom is critical to broadcast corporate irresponsibility and thereby to generate illegitimacy spillovers (i.e. diffusion of perceptions of illegitimacy of a given firm) (Kostova and Zaheer, 1999) into the local context. Second, in countries characterized by strong press and speech freedoms, local stakeholders are more critical of and better informed about any wrongdoing (Baughn et al., 2007; Lattemann et al., 2009; Puncheva-Michelotti et al., 2010), which in turn reflects on firms' reputational capital and local survival. On these grounds it is plausible to argue that BRIC firms will need to make extra efforts to gain legitimacy in such contexts - e.g. by engaging in CSR activities exemplified by excellent transparency and accountability in relation to ESG matters. Hence we propose that, first, the level of host countries' press and speech freedom positively influences BRIC firms' commitment in CSR initiatives, and that some initiatives - particularly so for reporting initiatives oriented at ensuring transparency - may be given more prominence than others in host countries where press and speech freedom is high. 


\subsection{Home country isomorphic pressures}

While international pressure to conform to certain CSR standards may play a significant role in the adoption of CSR policies, existing narratives on CSR adoption in BRIC firms point to the importance of home country factors. Certainly, as discussed in section 2, countries' key stakeholders - either in the form of governmental agencies or other institutions/actors (see e.g. the Ethos Institute in Brazil) - may be necessary to give an initial impetus to the adoption of certain CSR initiatives, but what we are interested in here is understanding whether the adoption of certain CSR initiatives may be the result of processes of mimetic isomorphism operating at the country level, as suggested by neo-institutional theories (DiMaggio and Powell, 1983).

Mimetic behaviours normally stem from uncertainty or the organization facing a problem of ambiguity. In such conditions, "organizations tend to model themselves after similar organizations in their field that they perceive to be more legitimate and successful" (DiMaggio and Powell, 1983, p. 152). Narratives on the diffusion of CSR practices highlight that firms operating in a restrictive environment are subject to a contagion or mimetic isomorphism effect resulting in companies emulating the behaviour of other firms in the country in relation to adoption of a CSR policy (Matten and Moon, 2008; Rivoli and Waddock, 2011). Also, Aguilera et al. (2007) have suggested that firms have relational motives for engaging in CSR policies, which means that firms undertake particular CSR initiatives in order to be seen as legitimate by other large firms in their home country. This is likely to apply particularly in the case of many emerging economies that are characterized by oligopolistic market structures, and by a dominance of the largest firms. Hence, we expect that such kind of home country isomorphic pressures will play a role in shaping all kinds of CSR instruments BRIC firms adopt in their attempt to become legitimized.

\section{Methodology}

\subsection{Data}

Our analysis is based on a new firm-level dataset that includes information on some 60 BRIC country firms. We selected these 
corporations from the Forbes Global 2000 ranking for 2011. The focus on large corporations is justified by the fact that large firms possess the resources and capacity to invest in CSR policies. We adopt a stratified random sampling approach with equal allocation to select 15 firms from the list of Forbes Global 2000 firms for each of the BRIC countries. The firms in our sample belong mainly to the energy ( 43 per cent both extractive and distribution), banking (23 per cent); and metals and mining (18 per cent) sectors. The remaining 16 per cent firms are active in pulp and paper, electrical equipment, telecommunications, etc. ${ }^{7}$ Our analysis covers the period 2003-2010. For a full list of firms and industries see Appendix A.

\subsection{Analysis}

\subsubsection{Dependent variables}

To represent the general involvement of firms into CSR initiatives we construct a composite index (CSR Index) measured as the average of the five indicators described below. CSR Index reflects the degree of engagement of firms in CSR activities on a scale of 0 to 1 , on the basis of the number of initiatives undertaken.

To account for the different CSR initiatives, we have constructed the following indicators:

1) Social Policies refers to the firm's "socially responsible policies", which include philanthropic initiatives, donations, and other activities that benefit different types of stakeholders such as employees and the community at large. We are interested in the number of years of the firm's involvement in such initiatives and particularly the start year. We consider this to be an important dimension of CSR because corporate responsibility towards society traditionally has been present in many BRIC firms (section 2). We retrieved this information via direct contacts with corporations and corporate websites especially the pages dedicated to CSR, commonly identified as "Corporate Social Responsibility," or

7 Note that these sectors are not necessarily representative of the industry specializations of BRIC countries, but are representative of their biggest public companies covered by the Forbes Global 2000 ranking. 
variations (e.g. "Social Responsibility", "Corporate Responsibility and Sustainability", etc.) Social Policies is a dummy variable that takes the value 1 if the firm has undertaken any kind of social policy at time $t$, and 0 otherwise. ${ }^{8}$

2) CSR Report refers to the firm's issuance of a CSR report, either as a separate report or as a section in its annual reports. We scrutinized the reports to avoid including reports that contained no information of value. The variable CSR Report takes the value 1 if the firm produced a CSR report at time $t$, and 0 otherwise.

3) GRI Report is based on firms' participation in the GRI. In this case, we collected information on number of years that the firm produced an accountability report following GRI guidelines, from the GRI website and corporate websites. The variable GRI Report takes the value 1 if the firm adopted GRI standards at time $t$, and 0 otherwise.

4) UNGC Member relies on information about each firm's participation in the UNGC. Since firms can be expelled from the UNGC after two years of non-reporting, we collected information on the years when a Communication of Progress was submitted to the UN Global Compact, from the UNGC website. The variable UNGC Member takes the value 1 if the firm was a UNGC member at time $t$, and 0 otherwise. In our sample, we found no cases of non-communication or de-listing.

5) UNGC Contr is based on information on whether and when our sample firms contributed to the Foundation for the Global Compact. Our index reports only whether a firm contributed (the variable takes the value of 1 ) or not (0) to the Foundation, without taking account of the amount of the contribution. ${ }^{9}$

${ }^{8}$ We are aware that firms' investments in social policies may vary widely, and that our binary variable cannot capture such a variation. Since we could not rely on any objective and reliable investment data on social policies over the period analyzed we use a binary variable. Hence, the variable Social Policies is a signal that firms undertake these activities, rather than a measure of how much they spend on them. This also serves the need of homogenizing this indicator - in terms of measurement scale - with the other CSR indicators, which are used to construct the composite index.

9 However, as Sethi and Schepers (2013) suggest, corporate support is generally miniscule, especially compared to the annual budgets of contributing firms. 
Descriptive statistics of these variables are presented in table 1. Figure 1 reports the percentage of firms in our sample that adopted each of the CSR initiatives discussed above at any year in the period 2003-2010. As expected, Social Policies are well diffused among BRIC firms, which is consistent with narratives on the adoption of philanthropic initiatives towards society in general in these countries. Notice also that the importance of CSR reporting increases over time, with the full sample publishing a CSR report in 2010. However, at the end of the period, only 40 per cent of them were adopting GRI reporting standards. Adherence to the UNGC, and especially financial support for the Foundation, are less common in our sample, with 50 per cent of the firms adhering to the UNGC at the end of the period, and less than 10 per cent of the firms contributing to the UNGC Foundation over the period analysed.

Figure 1. Adoption of Different Types of CSR Initiatives

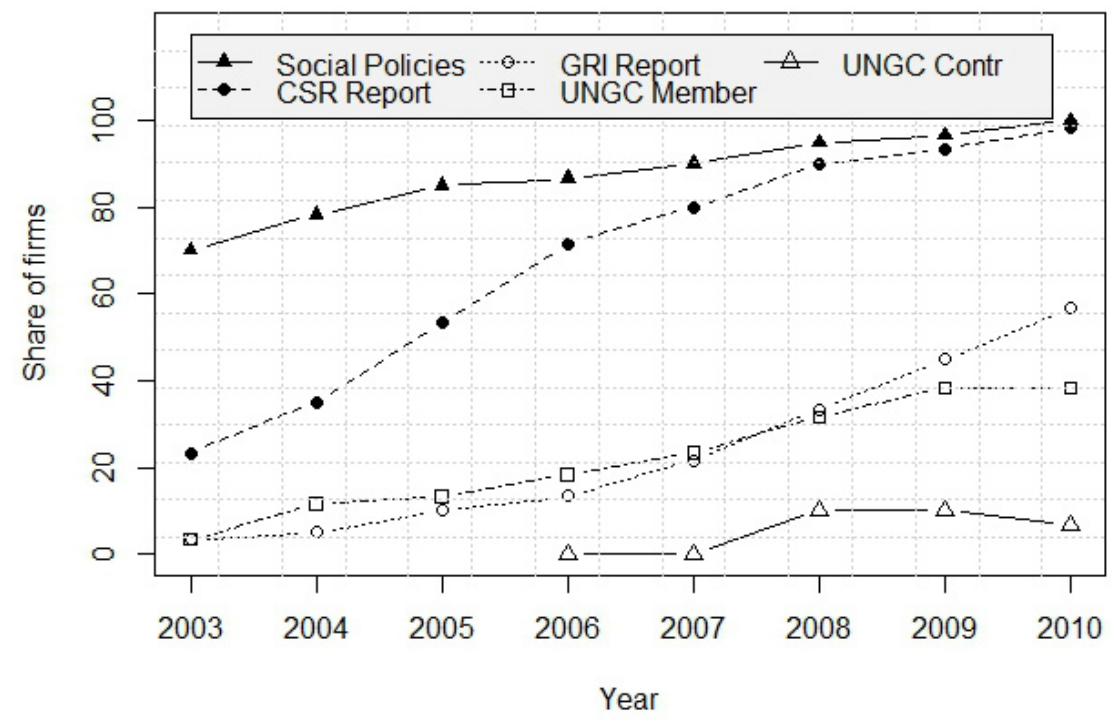

Source: Authors' own elaboration.

Note: The vertical axis reports the share of firms in the sample that have adopted a given CSR initiative by year. Data are based on the full sample. 


\subsubsection{Independent variables}

\section{Press Freedom}

We develop an indicator that measures the extent to which a firm's portfolio of international investments includes countries with high (or low) protection of political rights to a free press and free speech (Press Freedom). To account for the process of firms' internationalization, we rely on three complementary data sources. We use FDI Markets as the source for greenfield and brownfield foreign direct investments (FDI), and the Zephyr and SDCPlatinum databases for mergers and acquisitions (M\&A) where we consider only majority and full stake M\&A. To measure host countries' press and speech freedom, we rely on the Cingranelli and Richards (CIRI) Freedom of Speech indicator, ${ }^{10}$ which indicates the extent to which free speech and free press are affected by government censorship, including ownership of media outlets. A score of 1 indicates that government censorship of the media is total; 2 indicates that there is some government censorship of the media; and a score of 3 indicates that there is no government censorship of the media in a given year. ${ }^{11}$ The index Press Freedom for firm $i$ at time $t$ is defined as follows. First, we consider the number of countries in which firm $i$ invested up to time $t\left(\# C N C_{i t}\right)$, then we multiply the CIRI press freedom values (1-3) for each investment destination country up to time $t$, and divide the value obtained by $\# C N C_{i t}$. We obtain a variable ranging from 0 if there are no foreign investments, to a maximum of 3 . Figure 2 shows that, in our sample, firms from Brazil and India invest in countries characterized by higher press freedom compared to the Russian Federation and China. China's investments tend to be concentrated in countries with poor press freedom records, although over time the tendency reduces. Descriptive statistics are presented in Table 1.

${ }^{10}$ Details of the CIRI Project are available at http://www.humanrightsdata.org/

${ }^{11}$ Due to the need to distinguish between firms with no foreign investments and those investing in countries with low levels of press freedom, we recoded the index that originally went from 0 to 2 . 
Figure 2. Press and Speech Freedom of Host Countries

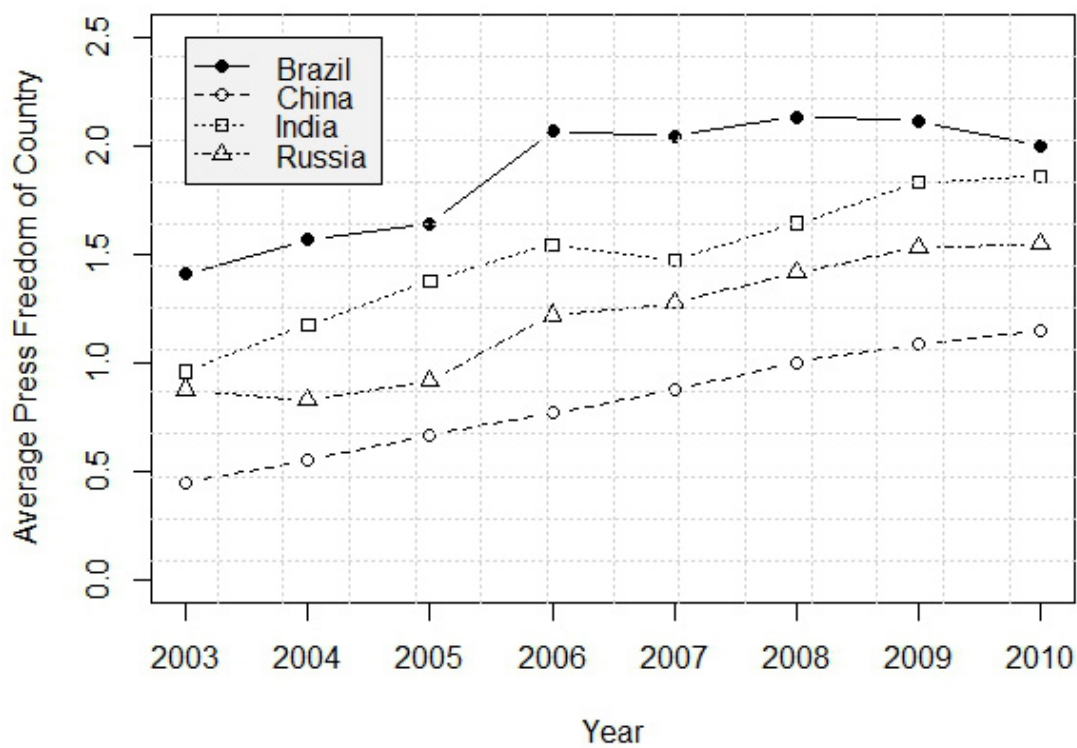

Source: Authors' own elaboration.

Note: The vertical axis reports the average value of the Press Freedom indicator by year by BRIC country.

\section{Home Country Isomorphism}

To measure the home country's mimetic isomorphism, we develop an indicator (HC Isomorphism) which, for firm $i$, is measured as the share of all Forbes Global 2000 firms (2011 edition) belonging to the same country as firm $i$, that adopted the specific CSR initiative i.e. Social Policies, CSR Report, GRI Report, UNGC Membership, UNGC Contribution - at time $t .{ }^{12}$ Descriptive statistics of this variable are presented in table 1.

\subsubsection{Control Variables}

We also include a set of control variables in the analysis (Descriptive statistics in Table 1). We account for factors that could explain involvement in CSR policies, based on earlier research. These

12 In the 2011 Edition of Forbes Global 2000 there are 33 Brazilian firms, 20 Russian, 60 Indian and 133 Chinese firms. 
include firm size (Size) based on log number of workers in each year (expressed in thousands); firm age (Age) and ownership status (SOEs) i.e. state (coded as 1 ) versus private ownership (coded as 0 ). Ownership status is important because SOEs may have different need to seek legitimacy compared to private firms (Marquis and Qian, 2014). The percentage of SOEs in the Indian sample is 33 per cent; 20 per cent in the Chinese sample and 7 per cent each in the Russian and Brazilian samples. Based on earlier research (Strike et al., 2006; Fischer and Sawczyn, 2013; Surroca et al., 2010), we do also control for firms' performance and risk. To do so we use Return on Equity (ROE at $t-1$ ), measured as the ratio between firm $i$ net income and equity at $t-1$, and we measure firm's risk (Risk) on the basis of ROE's volatility (i.e. based on ROE's annual fluctuations around its trend value (calculated by a penalized spline regression). In the model where the dependent variable is Social Policies, we do also control for the level of firm's innovativeness (Patents) based on the number of family patents (INPADOC) ${ }^{13}$ held by firm $i$ at time $t$, normalized by the log number of firm $i$ workers in each year. ${ }^{14}$ Patent data are retrieved from the PATSTAT database. To control for firms' internationalization we develop a quantitative indicator to measure the number of different countries in which the firm has invested (in the form of greenfield, brownfield, majority, or full stake M\&A) in each year during the period 2003-2010 (International). Finally, we control for firms' past social irresponsibility (Social Irresp), since previous research has suggested that firms with a track record of bad deeds are more likely to invest in different kinds of CSR activities to offset the negative reputation impacts of their earlier irresponsible actions (Mueller and Krausll, 2011; Kotchen and Moon, 2012). To account for the social irresponsibility of firms we draw on Giuliani et al. (2013) and collect information on events of human rights abuses in which our sample firms have been involved. This information was retrieved directly from the Business and Human Rights Resource Centre (BHRRC), considered the world's leading independent information hub

13 See http://www.epo.org/searching/essentials/patent-families/inpadoc.html, last accessed $6^{\text {th }}$ May 2014.

14 We controlled for innovation in this model because it is generally understood that the innovative effort of firms may relate to the social and environmental innovations of a firm, and therefore to its capacity to engage in different types of social policies in favor of a wide variety of stakeholders (see e.g. Surroca et al., 2010). We did not use $R \& D$ statistics, as it is common in this kind of studies, because such data are unavailable for most BRIC firms. 
Table 1. Descriptive Statistics

\begin{tabular}{|c|c|c|c|}
\hline Variable & Min & Max & Mean (Proportion) \\
\hline \multicolumn{4}{|l|}{ a. Dependent Variables } \\
\hline CSR Index & 0 & 1 & 0.301 \\
\hline Social Policies & 0 & 1 & $(0.637)$ \\
\hline CSR Report & 0 & 1 & $(0.333)$ \\
\hline GRI Report & 0 & 1 & $(0.168)$ \\
\hline UNGC Member & 0 & 1 & (0.173) \\
\hline UNGC Contr & 0 & 1 & $(0.054)$ \\
\hline \multicolumn{4}{|l|}{ b. Independent Variables } \\
\hline Press Freedom & 0 & 3 & 1.73 \\
\hline HC Isomorphism CSR Index & 0 & 0.618 & 0.200 \\
\hline HC Isomorphism Social Policies & 0 & 0.939 & 0.424 \\
\hline HC Isomorphism CSR Report & 0 & 0.917 & 0.246 \\
\hline HC Isomorphism GRI Report & 0 & 0.697 & 0.110 \\
\hline HC Isomorphism UNGC Member & 0 & 0.455 & 0.113 \\
\hline HC Isomorphism UNGC Contr & 0 & 0.091 & 0.020 \\
\hline \multicolumn{4}{|l|}{ c. Control Variables } \\
\hline Size & -2.450 & 15.810 & 9.830 \\
\hline Age & 0 & 202 & 40.100 \\
\hline SOES & 0 & 1 & $(0.229)$ \\
\hline$R O E$ & -0.420 & 1.391 & 0.167 \\
\hline Risk & 0 & 10.038 & 0.128 \\
\hline International & 0 & 58 & 6.38 \\
\hline Social Irresp & 0 & 27 & 0.992 \\
\hline Banking & 0 & 1 & $(0.25)$ \\
\hline Heavy Industry & 0 & 1 & $(0.017)$ \\
\hline PharmaChem & 0 & 1 & $(0.033)$ \\
\hline Extractive & 0 & 1 & $(0.20)$ \\
\hline Steel & 0 & 1 & (0.17) \\
\hline \multicolumn{4}{|l|}{ All other industries } \\
\hline $\begin{array}{l}\text { (Aerospace, Electricity and other } \\
\text { Utilities, Food and Beverages, Pulp } \\
\text { and Paper, Real Estate, TLC) }\end{array}$ & 0 & 1 & $(0.33)$ \\
\hline Patents & 0 & 53.59 & 1.407 \\
\hline
\end{tabular}


on the positive and negative impacts of corporations on human rights, and was the source used for the Addendum to Special Representative John Ruggie's 2008 report to the UN Human Rights Council (Wright, 2008). ${ }^{15}$ Our search resulted in more than a 100 documents, including news and reports providing evidence of events of negative human rights impacts that occurred up to 2010. For each year we coded into our dataset the number of abusing events a firm was reported to be involved in at time $t$. Our indicator Social Irresp is the sum of the firm $i$ abusing events up to time $t$.

We also control for country-specificities (country dummies with the Russian Federation as our reference group), since each BRIC country has a different history, and different regulation and internal institutional arrangements which may condition firms' adoption of CSR policies (as discussed in section 2). We include industry dummies to control for adoption of CSR policies being induced by intra-industry drivers (e.g. industry codes of conducts, industry specificities, etc.) We control for the sectors that we consider to be the most problematic based on earlier research showing that firms in these sectors have negative effects on different types of stakeholders (banking (Banking), heavy industries (Heavy Industry), pharmaceutical and chemical industry (PharmaChem), extractive (Extractive) and steel industry (Steel)), and may therefore have a different attitude towards CSR compared to firms in relatively less problematic sectors (our reference group of relatively less critical industries, including aerospace, electricity and other utilities, food and beverages, pulp and paper, real estate and telecommunications).

\subsection{Estimation Method}

We use an unbalanced panel of firms, with a Random Effects (RE) or a Fixed Effects (FE) model. ${ }^{16}$ We estimate the following baseline linear probability model (Model 1):

$$
\begin{aligned}
& \operatorname{Pr}\left(\text { CSR Index } \text { it }_{\mathrm{it}}\right)=\alpha_{0}+\alpha_{1} \text { PressFreedom }_{\mathrm{it}}+\alpha_{2} \text { HC Isomorphism } \\
& \alpha_{4} \text { Size }_{\mathrm{it}}+\alpha_{5} \text { Age }_{\mathrm{it}}+\alpha_{6} \text { SOE }_{\mathrm{it}}+\alpha_{7} R O E_{\mathrm{it}-1}+\alpha_{8} \text { Risk }_{\mathrm{it}}+\alpha_{9} \text { International }_{\mathrm{it}}
\end{aligned}
$$

15 See Business \& Human Rights Resource Centre at: http://www.businesshumanrights.org/Aboutus/Briefdescription, last accessed $6^{\text {th }}$ May 2014.

${ }^{16}$ We apply the Hausmann test to decide between a RE and a FE (Wooldrige, 2010, p. 328). 


$$
\begin{aligned}
& +\alpha_{10} \text { Social Irresp }_{\mathrm{it}-1}+\alpha_{11} \text { Home country Dummies }_{\mathrm{i}}+\alpha_{12} \text { Industry } \\
& \text { Dummies }_{\mathrm{i}}+\mu_{\mathrm{it}}(1)
\end{aligned}
$$

The baseline model is also estimated for each of the other five dependent variables: Social Policies (Model 2); CSR Report (Model 3); GRI Report (Model 4); UNGC Member (Model 5); UNGC Contr (Model 6). As mentioned earlier, in Model 2 we also control for Patents it In all the estimates $p$-values are calculated on the basis of robust standard errors given the presence of serial and cross-sectional correlation in the errors (we test for this, see Wooldridge, 2010, p. 319). All the models report the statistics of the adjusted $R^{2}$. All the estimates are made in $R$ and performed by routines contained in several packages, primarily plm (Croissant and Millo, 2008).

\section{Empirical Results}

Table 2 shows the results of the estimations which report the factors affecting the level of firms engagement in different types of CSR policies (the correlation table is in Appendix B). First, we estimate Model 1 with CSR Index as the dependent variable; we find that the more firms invest in countries with more press freedom, the higher is their involvement in CSR initiatives $(\beta=0.031, p<0.01)$. Next we do find that local isomorphic pressures do also relate to a firm's engagement of CSR activities $(\beta=0.977, p<0.01)$. Among the results of the control variables it is interesting to notice that the degree of international openness of firms per se (International) does not relate to firms' engagement in CSR initiatives, pointing at the fact that what matters is the quality and characteristics of host countries - i.e. in the context of this study their level of press and speech freedom. Moreover, we find that past irresponsible behaviours by firms is associated with their higher involvement into CSR policies, in line with earlier research about the instrumental and symbolic use firms make of CSR (Kotchen and Moon, 2012). Also, Chinese and Indian firms engage more intensively in different kinds of CSR initiatives as compared to the reference group of Russian firms, in line with the narratives of section 2. Our results show also that firms in the banking and heavy industries are less likely to engage in CSR initiatives compared to the reference group.

These results about the general engagement of BRIC firms in a portfolio of CSR initiatives change somewhat if we disaggregate 
the dependent variable into different CSR initiatives (table 2, Models 2-6). We find three sets of results. First, press and speech freedom stays significant only in Model 3 (CSR Report is the dependent variable) ( $\beta=0.101, p<0.01$ ), which suggests that $B R I C$ firms investing predominantly in countries with high press freedom are more likely than firms with investments in countries characterized by lower press freedom to issue CSR reports. The level of press and speech freedom of the host country is neither related to the adoption of GRI reporting standards (Model 4), nor to the adherence and contribution of BRIC firms to the UNGC (Models 5-6). Second, home country's isomorphic pressures are significantly related to all kinds of reporting and principlebased initiatives (table 2, Models 3-6), namely CSR reporting ( $\beta=0.982$, $p<0.01)$, GRI reporting ( $\beta=1.284, p<0.05)$, UNGC membership $(\beta=1.201$ $p<0.01)$ and UNGC contribution $(\beta=2.113, p<0.05)$. These results point at a contagion effect, whereby prior adoption of a given CSR initiative by the largest public companies in their home country stimulates further adoptions by BRIC firms. Third, we find that the adoption of Social Policies (Table 2, Model 2) is neither related to the level of press and speech freedom of the host country, nor to home country isomorphic pressures.

Results for some of the control variables are interesting. In none of our models, the degree of firms' internationalization (International) is related to the adoption of CSR policies, which contradicts earlier research (see Strike et al., 2006). Moreover, firms with a stronger track record of bad deeds (Social Irresp) are more likely to adopt GRI reporting standards $(\beta=0.022, p<0.01)$, as well as to adhere to and fund the UNGC ( $\beta=0.031, p<0.05$ and $\beta=0.091, p<0.01$ respectively). Firms with higher ROE volatility (Risk) are also more likely to engage in both reporting initiatives (CSR Report and GRI Report) $(\beta=0.038, p<0.05$ and $\beta=0.064$, $p<0.01$ respectively) in line with the idea that risky operations may lead firms to proactively reduce their risk by engaging in CSR initiatives that improve their legitimacy through higher transparency. Also, unlike suggested by earlier research (Li and Zhang, 2007; Marquis and Qian, 2014) we do not generally find significant differences between SOEs and privately owned firms, with the exception that SOEs are more likely than privately owned firms to adhere to the UNGC $(\beta=0.160, p<0.10)-$ possibly because they are under direct governmental pressure to do so. 
Table 2. Results of Regression Analyses

\begin{tabular}{|c|c|c|c|c|c|c|}
\hline Model & (1) & (2) & (3) & (4) & (5) & (6) \\
\hline $\begin{array}{l}\text { Dependent } \\
\text { variable }\end{array}$ & CSR Index & $\begin{array}{l}\text { Social } \\
\text { Policies }\end{array}$ & CSR Report & GRI Report & $\begin{array}{l}\text { UNGC Mem- } \\
\text { ber }\end{array}$ & $\begin{array}{l}\text { UNGC } \\
\text { Contr }\end{array}$ \\
\hline Model & (RE) & (FE) & (RE) & (RE) & (RE) & (FE) \\
\hline Press Freedom & $\begin{array}{c}0.031 * * * \\
(0.012)\end{array}$ & $\begin{array}{c}0.027 \\
(0.025)\end{array}$ & $\begin{array}{c}0.102 * * * \\
(0.030)\end{array}$ & $\begin{array}{c}0.023 \\
(0.022)\end{array}$ & $\begin{array}{l}-0.004 \\
(0.022)\end{array}$ & $\begin{array}{c}-6.51 e-03 \\
(2.04 e-02)\end{array}$ \\
\hline HC Isomorphism & $\begin{array}{c}0.978 * * * \\
(0.128)\end{array}$ & $\begin{array}{l}-0.148 \\
(0.315)\end{array}$ & $\begin{array}{c}0.983^{* * *} \\
(0.106)\end{array}$ & $\begin{array}{c}1.284^{* * *} \\
(0.216)\end{array}$ & $\begin{array}{c}1.201 * * * \\
(0.315)\end{array}$ & $\begin{array}{c}2.11 \mathrm{e}+00^{* *} \\
(9.74 \mathrm{e}-01)\end{array}$ \\
\hline Size & $\begin{array}{c}0.010 \\
(0.012)\end{array}$ & $\begin{array}{c}0.005 \\
(0.048)\end{array}$ & $\begin{array}{c}0.018 \\
(0.024)\end{array}$ & $\begin{array}{c}-0.033^{*} \\
(0.020)\end{array}$ & $\begin{array}{c}0.050 * * \\
(0.024)\end{array}$ & $\begin{array}{c}4.34 \mathrm{e}-05 \\
(2.32 \mathrm{e}-02)\end{array}$ \\
\hline Age & $\begin{array}{c}0.001 \\
(0.001)\end{array}$ & $\begin{array}{c}0.024 \\
(0.020)\end{array}$ & $\begin{array}{c}0.001 \\
(0.001)\end{array}$ & $\begin{array}{c}0.002 * * * \\
(0.001)\end{array}$ & $\begin{array}{c}0.001 \\
(0.001)\end{array}$ & $\begin{array}{l}-1.20 e-02 \\
(9.44 e-03)\end{array}$ \\
\hline SOES & $\begin{array}{c}0.004 \\
(0.039)\end{array}$ & $\begin{array}{c}0.087 \\
(0.059)\end{array}$ & $\begin{array}{l}-0.112 \\
(0.074)\end{array}$ & $\begin{array}{l}-0.029 \\
(0.058)\end{array}$ & $\begin{array}{l}0.160^{*} \\
(0.095)\end{array}$ & - \\
\hline$R O E$ & $\begin{array}{l}-0.087 \\
(0.079)\end{array}$ & $\begin{array}{l}-0.040 \\
(0.180)\end{array}$ & $\begin{array}{l}-0.171 \\
(0.186)\end{array}$ & $\begin{array}{c}0.026 \\
(0.172)\end{array}$ & $\begin{array}{l}-0.256 \\
(0.197)\end{array}$ & $\begin{array}{c}-9.59 e-02 \\
(1.28 e-01)\end{array}$ \\
\hline Risk & $\begin{array}{c}0.017^{* * *} \\
(0.005)\end{array}$ & $\begin{array}{l}-0.013 \\
(0.011)\end{array}$ & $\begin{array}{c}0.038 * * \\
(0.017)\end{array}$ & $\begin{array}{c}0.064 * * * \\
(0.013)\end{array}$ & $\begin{array}{l}-0.013 \\
(0.017)\end{array}$ & $\begin{array}{c}4.45 e-03 \\
(7.90 e-03)\end{array}$ \\
\hline International & $\begin{array}{c}0.001 \\
(0.002)\end{array}$ & $\begin{array}{c}0.007 \\
(0.009)\end{array}$ & $\begin{array}{l}-0.001 \\
(0.004)\end{array}$ & $\begin{array}{c}0.006 \\
(0.004)\end{array}$ & $\begin{array}{c}0.003 \\
(0.005)\end{array}$ & $\begin{array}{c}-4.71 e-03 \\
(3.38 \mathrm{e}-03)\end{array}$ \\
\hline Social Irresp & $\begin{array}{c}0.013^{*} \\
(0.007)\end{array}$ & $\begin{array}{l}-0.001 \\
(0.021)\end{array}$ & $\begin{array}{l}-0.005 \\
(0.004)\end{array}$ & $\begin{array}{c}0.022 * * * \\
(0.007)\end{array}$ & $\begin{array}{c}0.031^{* *} \\
(0.012)\end{array}$ & $\begin{array}{c}9.10 \mathrm{e}-02^{* *} \\
(2.68 \mathrm{e}-02)\end{array}$ \\
\hline Brazil & $\begin{array}{l}-0.016 \\
(0.061)\end{array}$ & - & $\begin{array}{c}0.087 \\
(0.107)\end{array}$ & $\begin{array}{c}-0.210 * * \\
(0.094)\end{array}$ & $\begin{array}{c}0.021 \\
(0.126)\end{array}$ & - \\
\hline China & $\begin{array}{c}0.149 * * * \\
(0.046)\end{array}$ & - & $\begin{array}{c}0.244 * * * \\
(0.082)\end{array}$ & $\begin{array}{c}0.244 * * * \\
(0.078)\end{array}$ & $\begin{array}{c}0.131 \\
(0.113)\end{array}$ & - \\
\hline India & $\begin{array}{c}0.130 * * \\
(0.052)\end{array}$ & - & $\begin{array}{c}0.209 * * \\
(0.082)\end{array}$ & $\begin{array}{c}0.079 \\
(0.077)\end{array}$ & $\begin{array}{c}0.113 \\
(0.123)\end{array}$ & - \\
\hline Banking & $\begin{array}{c}-0.089 * * \\
(0.042)\end{array}$ & - & $\begin{array}{l}-0.049 \\
(0.074)\end{array}$ & $\begin{array}{c}-0.182^{* * *} \\
(0.066)\end{array}$ & $\begin{array}{c}-0.228 * \\
(0.123)\end{array}$ & - \\
\hline Heavy Industry & $\begin{array}{c}-0.152^{* * *} \\
(0.049)\end{array}$ & - & $\begin{array}{c}0.225^{* * *} \\
(0.085)\end{array}$ & $\begin{array}{c}0.087 \\
(0.070)\end{array}$ & $\begin{array}{c}-0.386 * * * \\
(0.106)\end{array}$ & - \\
\hline PharmaChem & $\begin{array}{l}-0.157 \\
(0.119)\end{array}$ & - & $\begin{array}{l}-0.262 \\
(0.203)\end{array}$ & $\begin{array}{c}-0.197 * * \\
(0.088)\end{array}$ & $\begin{array}{c}0.018 \\
(0.095)\end{array}$ & - \\
\hline Extractive & $\begin{array}{c}0.070 \\
(0.050)\end{array}$ & - & $\begin{array}{c}0.206 * * * \\
(0.080)\end{array}$ & $\begin{array}{l}0.147^{*} \\
(0.082)\end{array}$ & $\begin{array}{l}-0.060 \\
(0.138)\end{array}$ & - \\
\hline Steel & $\begin{array}{l}-0.042 \\
(0.071)\end{array}$ & - & $\begin{array}{c}0.083 \\
(0.092)\end{array}$ & $\begin{array}{l}-0.087 \\
(0.107)\end{array}$ & $\begin{array}{c}-0.290 * * \\
(0.139)\end{array}$ & - \\
\hline UNGC Member & - & - & - & - & - & $\begin{array}{c}7.62 \mathrm{e}-02 \\
(6.37 \mathrm{e}-02)\end{array}$ \\
\hline Patent & - & $\begin{array}{c}0.007 \\
(0.005)\end{array}$ & - & - & - & - \\
\hline Num observations & 456 & 456 & 456 & 456 & 456 & 294 \\
\hline Adjusted $\mathrm{R}^{2}$ & 0.425 & 0.125 & 0.431 & 0.289 & 0.280 & 0.175 \\
\hline F statistic & $\begin{aligned} & 20.439(\mathrm{df} \\
= & 17 ; 438)^{* * *}\end{aligned}$ & $\begin{array}{c}\quad 6.680(\mathrm{df} \\
=10 ; 386)^{* * *}\end{array}$ & $\begin{aligned} & 20.938(\mathrm{df} \\
= & 17 ; 438)^{* * *}\end{aligned}$ & $\begin{aligned} & 11.113(\mathrm{df} \\
= & 17 ; 438)^{* * *}\end{aligned}$ & $\begin{aligned} & 10.611(\mathrm{df} \\
= & 17 ; 438)^{* * *}\end{aligned}$ & $\begin{aligned} & 7.431(\mathrm{df} \\
= & 9 ; 225)^{* * *}\end{aligned}$ \\
\hline
\end{tabular}

Note: ${ }^{* \star}$ p-value $<0.01 ;{ }^{* *} p$-value $<0.05 ;{ }^{*} p$-value $<0.1$; standard errors in brackets. 
Finally, among the other control variables, note that there are some significant differences across countries in terms of the adoption of CSR reports and GRI standards - i.e. Chinese and Indian firms are more likely to issue CSR reports compared to Russian firms $(\beta=0.243$, $p<0.01$ and $\beta=0.208, p<0.05$ respectively); Brazilian are less likely, and Chinese are more likely than Russian firms to adopt GRI standards ( $\beta=-$ $0.210, p<0.05$ and $\beta=0.244, p<0.01$ respectively). We do also find that firms in the heavy and extractive industries are more likely than the reference group to issue CSR reports $(\beta=0.224, p<0.01$ and $\beta=0.205$, $p<0.01$ respectively); firms in the extractive industry are also more likely than the reference group to adhere to GRI reporting standards ( $\beta=0.147, p<0.10)$, while the opposite is true for the banking and the chemical/pharmaceutical industries' firms $(\beta=-0.181, p<0.10$ and $\beta=$ $-0.197, p<0.05$ respectively). Moreover, adherence to the UNGC is less likely in the banking $(\beta=-0.228, p<0.10)$, heavy industry $(\beta=-0.385$, $p<0.01)$ and steel industry firms $(\beta=-0.290, p<0.05)$, as compared to the reference group.

\section{Discussion and Conclusions}

In the search for legitimacy, BRIC firms can choose from several CSR instruments. Extant research shows that BRIC firms are not unfamiliar with the concept of corporate philanthropy or of contributing to employees' and community welfare. They have engaged in such practices for a long period of time based on religious or cultural motivations, or the provisions of the government policies. However, as BRIC economies became more global and their business sectors more internationalized, scholars have noted the changing attitude of their firms, which have undertaken diverse international CSR reporting and principle-based initiatives, including disclosure of their CSR activities through explicit CSR reports, adoption of GRI reporting standards, adherence to the UNGC and the financial contribution to its Foundation. Our paper explored the kinds of CSR instruments BRIC firms are most likely to adopt in response to different home and host country isomorphic pressures.

We found support for the idea that BRIC firms that internationalize seek to overcome their LOF/LOE when entering a new market using the instrument of CSR reporting. Our study points at the fact that CSR reports are issued more when BRIC firms' investments are directed 
towards countries characterized by high levels of press and speech freedoms. Since in these countries the press and watchdog organizations are more active in broadcasting news of corporate wrongdoing, and local populations may be more inclined to think critically, BRIC firms use CSR reports to enhance their transparency and accountability. In this respect, our results differ from earlier research - i.e. Brammer et al. (2009) who find that United Kingdom companies increase their charitable giving when they invest in host countries with low levels of civil and political rights in order to hedge against reputational risks. A plausible interpretation may have to do with the different home country institutional background existing between BRIC and United Kingdom firms. In this respect BRIC firms may seek legitimacy by mimicking international practices if this is what the host countries demand - such as in the case of countries with strong press and speech freedom whereas in countries characterized by an institutional void or by authoritarian regimes and "greedy elites" (Keen, 2003; Collins, 2009), where press and speech freedom are notably poor and repressed, legitimacy is sought through other channels. Hence, in this latter case, the search for legitimacy is not merely a function of isomorphism, but may involve a "political process of interaction, communication, and exchange, which creates a perception about an organization without its necessarily having to implement certain models and practices" (Kostova et al., 2008: 1001). In other words, in such contexts, the agency role of individual firms is crucial for negotiating business opportunities and manipulating the host environment to suit their own ends. Hence, in line with critical views on use of a neo-institutional approach to international firms' legitimacy building (Kostova et al., 2008), our results suggest that the host country context influences the way legitimacy is built up, and the role played by CSR in its process of social construction. One of our research contributions is therefore improving the understanding of international business from a neoinstitutional perspective (Husted and Allen, 2006; Kostova et al., 2008), by providing support for the idea that internationalizing firms may use different strategies to gain legitimacy, depending on the characteristics of the host country's institutional context.

Our results are also in line with neo-institutional theories in relation to the process of legitimacy building by firms within their own country. We find that all kinds of reporting and principle-based initiatives are subject to a form of mimetic isomorphism (DiMaggio 
and Powell, 1983), which is coherent also with most BRIC countries' historical accounts of CSR adoption. Based on these results, we can speculate that such bandwagon effects in the adoption of CSR initiatives are promoted by the initial pressures of key government organizations and NGOs, which since the early 2000s have had an increased interest in promoting the spread of CSR reporting and principle-based initiatives within their own national business sectors. A notable example is the UNGC. Governments of emerging economies support the UNGC because it is viewed as an instrument of "modernization" and greater economic integration (Kell, 2013). Subsequently, firms have adopted the UNGC by imitating each other and in a bid to be legitimized by their home institutions.

A different story, however, is to be told about the adoption of social policies, which appear unrelated to both host and home countries' recent institutional pressures, but, as our narratives in section 2 show, may be instead more anchored to the perennial individual commitment that BRIC firms have taken towards society at large - for religious, cultural, institutional and ethical motivations that are idiosyncratic in the history of each country. By identifying a difference between the adoption of social policies and other types of CSR initiatives, our paper contributes to the growing but still limited literature on CSR among emerging market firms (Chapple and Moon, 2005; Baskin, 2006; Visser, 2008; Gugler and Shi, 2009; Marquis and Qian, 2014, among others). We contribute to the understanding of the relationship between BRIC firms' internationalization and CSR policies, and suggest that BRIC firms may use certain CSR policies in a very instrumental fashion to enter demanding countries, or to please their ruling governments. Our results instead cast some doubts on the substantial value and commitment of BRIC firms to contributing to the global social good. Because we find that it is precisely firms with a past track record of social irresponsibility that are more likely to adopt GRI standards as well as adhere and support the UNGC, we ask whether BRIC firms are really closing the gap with Western ESG practices (assuming that Western ESG practices are more respectful of human rights), or are refining their capacity to only symbolically close this gap. We leave this question open for future research.

The results in this paper should be interpreted with some caution since our analysis has some data limitations. Our study is based 
on a restricted sample, whose extension we are currently working on. Moreover, similarly to other studies in this area of research (e.g. Strike et al., 2006; Marquis and Qian, 2014), our regression analyses do not control for potential endogeneity due to time-varying omitted variables, which clearly reduces our capacity to prove causality between dependent and independent variables. Next, our measure of internationalization relies only on FDI (greenfield, M\&A, etc.) and does not account for firms that export without investing abroad. This would be a serious problem if our sample covered mainly consumer goods (e.g. footwear, textile, consumer electronics, etc.), which can be exported without the need for any foreign investment. However, our sample includes sectors such as the extractive industries, banking, the utilities sectors, etc., where FDI is often the main mode of internationalization. Another important limitation that should be noted is that adoption of CSR initiatives as measured in this paper provides very little information on the substantial involvement of these companies - i.e. in terms of investments undertaken - in pursuing the social good. Earlier research on CSR reports, for instance, shows that firms tend to over-emphasize the positive side of their ESG conduct, while omitting crucial information on their irresponsible conduct (Boiral, 2013). The present study was not designed to investigate the repercussions of CSR initiatives for the effective ESG conduct of such firms, although research in this direction would be valuable (see Giuliani et al., 2013).

\section{References}

Aguilera R., Rupp, D. E., Williams, C. A., Ganapathi, J.(2007). "Putting the S back in corporate social responsibility: A multilevel theory of social change in organization," Academy of Management Review, 32(3): 836-863.

Amaldoss, M. X. and Manohar, H. L. (2013). "Communicating Corporate Social Responsibility - A Case of CSR communication in Emerging Economies", Corporate Social Responsibility and Environmental, 20: 65-80.

Apressyan, R. G. (1997). "Business ethics in Russia", Journal of Business Ethics, 16: 1561-1570.

Araya, M. (2006). "Exploring Terra Incognita non-financial reporting in corporate Latin America", Journal of Corporate Citizenship, 21: 25-38. 
Arevalo, J. A. and Aravind, D. (2011). "Corporate Social Responsibility practices in India: approach, drivers, and barriers", Corporate Governance, 11(4): $399-414$.

Arora, B. and Puranik, R. (2004). "A Review of Corporate Social Responsibility in India", Development, 47(3): 93-100.

Balasubramanian, N. K., Kimber, D., Siemensma, F.( 2005). "Emerging opportunities or traditions reinforced? An analysis of the attitudes towards CSR, and trends of thinking about CSR in India", Journal of Corporate Citizenship, 17: 79-92.

Baskin, J. (2006). "Corporate Responsibility in Emerging Markets", Journal of Corporate Citizenship, 24: 29-47.

Baughn, C. C., Bodie, N. L., McIntosh, J. C. (2007). "Corporate Social and Environmental Responsibility in Asian countries and other geographical regions", Corporate Social Responsibility and Environmental Management, 14: 189-205.

Bevins, V. (2011). “CSR: Brazil's CSR Leaders", Latin Trade. http://latintrade. com/2011/05/csr-brazil\%E2\%80\%99s-csr-leaders

Bo, H., Li, T., Toolsema, L. A. (2009). “Corporate Social Responsibility investment and social objectives: An examination on Social Welfare Investment of Chinese State Owned Enterprises", Scottish Journal of Political Economy, 56(3): 267-295.

Boiral, O. (2013). "Sustainability reports as simulacra? A counter-account of A and A+ GRI reports", Accounting, Auditing and Accountability Journal, 26(7): 1036-1071.

Brammer, S. Pavelin, S. and Porter, L. (2009) "Corporate charitable giving, multinational companies and controversial countries" Journal of Management Studies, 46(4), 575-596.

Campbell, J.T., Eden, L., Miller, S. R. (2012). "Multinationals and Corporate Social Responsibility in host countries: Does distance matter?", Journal of International Business Studies, 43: 84-106.

Chapple, W. and Moon, J. (2005). "Corporate Social Responsibility (CSR) in Asia - A Seven-country study of CSR web site reporting", Business \& Society, 44(4): 415-441.

Chaudri, V. and Wang, J. (2007). "Communicating Corporate Social Responsibility on the Internet: A case study of the top 100 Information Technology companies in India", Management Communication Quarterly, 21(2): 232-248.

Cheung, Y. L., Tan, W., Ahn, H.-J., Zhang, Z. (2010). “Does Corporate Social Responsibility matter in Asian Emerging Markets?", Journal of Business Ethics, 92: 401-413.

Collins, D. (2009). "The Failure of a socially responsive Gold Mining MNC in El Salvador: Ramifications of NGO Mistrust", Journal of Business Ethics, 88(2): 245-68.

Croissant, Y. and Millo, G. (2008). "Panel data econometrics in R: The plm Package", Journal of Statistical Software, 27(2): 1-43.

Crotty, J. (2009). "Making a difference? NGOs and civil society development in Russia", Europe-Asia Studies, 61(1): 85-108. 
DiMaggio, P. J. and Powell W. W. (1983). "The Iron Cage Revisited: Institutional isomorphism and collective rationality in organizational fields", American Sociological Review, 48:147-60.

Dobers, P. and Halme, M. (2009). "Corporate Social Responsibility and developing countries", Corporate Social Responsibility and Environmental Management, 16: 237-249.

Fischer, T.M. and Sawczyn, A.A., (2013). "The relationship between corporate social performance and corporate financial performance and the role of innovation: evidence from German listed firms", Journal of Management Control, 24: 27-51.

Gao, Y. (2011). "CSR in an emerging country: A content analysis of CSR reports of listed companies", 6(2), Baltic Journal of Management: 263-291.

Giuliani E., Macchi C., Fiaschi D. (2013). "Corporate Social Irresponsibility in International Business", in International Business and Sustainable Development, Ed. van Tulder R., Verbeke A., Strange R., Progress in International Business Research, Volume 8, European International Business Academy (EIBA)/Emerald: 141-172.

Giuliani, E., Gorgoni, S., Gunther, C., Rabellotti, R. (2014). "Emerging versus advanced country MNEs investing in Europe: A typology of subsidiary global-local connections", International Business Review, 23: 680-691.

Griesse, M. A.S (2007). “The geographic, political, and economic context for Corporate Social Responsibility in Brazil", Journal of Business Ethics, 73: 21-37.

Gugler, P. and Shi, J. Y. J. (2009). “Corporate Social Responsibility for Developing Country Multinational Corporations: Lost war in pertaining global competitiveness?", Journal of Business Ethics, 87: 3-24.

Gupta, A.D. (2007). "Social Responsibility in India towards global compact approach", International Journal of Social Economics, 34(9): 637-663.

Hawn, O. (2013). "How social legitimacy helps overcome low home country legitimacy: Corporate Social Responsibility and emerging market multinationals". Paper Presented at the 2013 Academy of Management Annual Meeting, Orlando, Florida.

Husted, B.W., Allen, D.B. (2006). “Corporate Social Responsibility in the Multinational Enterprise: Strategic and institutional approaches". Journal of International Business Studies, 37, 838-849.

Hymer, S. (1960/1976). The international operations of national firms: A study of direct investment. Cambridge, MA: MIT Press.

Ioannou, I.A, Serafeim, G.B. (2012) "What drives corporate social performance the role of nation-level institutions", Journal of International Business Studies, 43(9), 834-864.

Keen, D. (2003). "Greedy elites, dwindling resources, alienated youths: the anatomy of protracted violence in Sierra Leone", International Politics and Society, 2: 321-60.

Kell, G. (2005). "The Global Compact: Selected experiences and reflections", Journal of Business Ethics, 59(1/2), 69-79. 
Kell, G. (2013). "12 Years later: Reflections on the growth of the UN Global Compact", Business \& Society, 52(1): 31-52.

Kostova, T., Roth, K., Dacin, M. T. (2008). "Institutional theory in the study of multinational corporations: a critique and new directions", Academy of Management Review, 33(4): 994-1006.

Kostova, T. and Zaheer, S. (1999). "Organizational legitimacy under conditions of complexity: the case of the multinational enterprise", Academy of Management Review, 24(1): 64-61.

Kotchen, M. and Moon, J. (2012). "Corporate Social Responsibility for Irresponsibility," The B.E. Journal of Economic Analysis \& Policy, 12(1): 1-22.

Kuo, L., Yeh, C-C., Yu, H.-C. (2012). "Disclosure of Corporate Social Responsibility and Environmental Management: Evidence from China", Corporate Social Responsibility and Environmental Management, 19(5): 273-287.

Kuznetsov, A., Kutnetsova, O., Warren, R. (2009). "CSR and the legitimacy of business in transition economies: The case of Russia", Scandinavian Journal of Management, 25: $37-45$.

Lange D., Washburn N.T. (2012). "Understanding attributions of Corporate Social Irresponsibility", Academy of Management Review, 37(2): 300-326.

Lattemann, C., Fetscherin M., Alon, I., Schneider, A. (2009). "CSR communication intensity in Chinese and Indian multinational companies", Corporate Governance: An International Review, 174: 426-442.

Lee, S. (2010). "Corporate Social Responsibility in India. A case study for the OxfordAchilles working group on corporate social responsibility". Oxford Said Business School. http://www.sbs.ox.ac.uk/achilles/downloads/research/India.pdf

Lenssen, G., Bevan, D., Blagov, Y. (2011). "Corporate responsibility and emerging markets", Corporate Governance, 11(4): 308-312.

$\mathrm{Li}, \mathrm{H}$. and Zhang, Y. (2007). "The role of managers' political networking and functional experience in new venture performance: evidence from China's Transition economy", Strategic Management Journal, 28: 791-804.

Lin, L. W. (2010). "Corporate Social Responsibility in China: Window dressing or structural change?", Berkeley Journal Of International Law, 28(1): 64-100.

Madhok, A., Keyhani, M. (2012) "Acquisitions as entrepreneurship: Asymmetries, opportunities, and the internationalization of multinationals from emerging economies", Global Strategy Journal, 2(1): 26-40.

Marquis, C. and Qian, C. (2014). "Corporate social responsibility reporting in China: Symbol or substance?" Organization Science, 25(1): 127-148.

Mathews, J. A. (2006). "Dragon multinationals: New players in the 21st century globalization. Asia Pacific", Journal of Management, 23: 5-27. 
Matten, D. and Moon, J. (2008).'“Implicit' and 'Explicit' CSR: A conceptual framework for a comparative understanding of Corporate Social Responsibility", Academy of Management Review, 33(2): 404-424.

Medeiros Peliano, A.-M. T., Beghin, N., De Oliveira Neto, V. (2002). Philanthropy and Equity: The Case of Brazil, The Global Equity, Cambridge, MA: Harvard University.

Mezzadri, A. (2014). "Indian garment clusters and CSR norms: Incompatible agendas at the bottom of the garment commodity chain", Oxford Development Studies, forthcoming.

Mueller, A. and Krausll, R. (2011). "Doing good deeds in times of need: a strategic perspective on corporate disaster donations", Strategic Management Journal, 32: 911-929.

Narwal, M. and Sharma, T. (2008). "Perceptions of corporate social responsibility in India: An empirical study", Journal of Knowledge Globalization, 1(1): 61-79.

Peiyuan, G., Xubiao, Z., Ningdi, W. (2007). "A journey to discover values: study of sustainability reporting in China" A Study of Sustainability Reporting in China - A Journey to Discover Values", SynTao, Downloadable from: http://www.eldis.org/ go/topics/resource-guides/ethical-business/csr-in-china\&\&pg=2\#.U3nTbfl_tg1, Last Accessed 19 May 2014.

Preuss, L. and Barkemeyer, R. (2011). "CSR priorities of emerging economy firms: is Russia a different shape of BRIC?", Corporate Governance, 11: 371-385.

Puncheva-Michelotti, P., Michelotti, M., Gahan, P. (2010). “The relationship between individuals' recognition of Human Rights and responses to socially responsible companies: Evidence from Russia and Bulgaria", Journal of Business Ethics, 93: 583-605.

Puppim de Oliveira, J. (2008). "Corporate Citizenship in Latin America. New challenges for business", Journal of Corporate Citizenship, 27: 17-20.

Ramachandran J., Pant A. (2010) "The liabilities of origin: an emerging economy perspective on the cost of doing business abroad", in Ed. Devinney T., Pedersen T., Tihanyi L., The Past, Present, and Future of International Business and Management, Emerald, Bingley UK: 231-265.

Rasche, A. (2009). "Toward a model to compare and analyze accountability standards: The case of the UN Global Compact". Corporate Social Responsibility and Environmental Management, 16: 192-205.

Rasche, A., Waddock, S., McIntosh, M. (2013). "The United Nations Global Compact: Retrospect and prospect", Business and Society, 52(1): 6-30.

Raufflet, E. (2008). "Creating the context for Corporate Responsibility", Journal of Corporate Citizenship, 30: 95-106.

Rivoli, P. and Waddock, S.(2011). "First They Ignore You...: The time-context dynamic and corporate responsibility", California Management Review, 53(2): 87-104.

Rosefielde, S. and Hlouskova, R. (2007). "Why Russia is not a democracy", Comparative Strategy, 26: 215-229. 
Rugman, A. M. (2009). Theoretical aspects of MNEs from emerging economies. In R. Ramamurti \& J. Singh (Eds.), Emerging multinationals in emerging markets. Cambridge, UK: Cambridge University Press: 42-63.

Scharf, R. (2008). "Why Brazil Leads the Region in CSR", Quarterly Americas, http:// www.americasquarterly.org/node/288.

See, G. (2009). "Harmonious society and Chinese CSR: Is there really a link?", Journal of Business Ethics, 89: 1-22.

Sethi, S. P. and Schepers, D. H. (2013). "United Nations Global Compact: The promiseperformance gap", Journal of Business Ethics, February: 1-16.

Soboleva, I. (2006). "Corporate Social Responsibility, global context and Russian realities", Problems of Economic Transition, 49(8): 82-95.

Soobaroyen, T. and Ntim, C.G., (2013). "Social and environmental accounting as symbolic and substantive means of legitimation": The case of HIV/AIDS reporting in South Africa", Accounting Forum, 37(2): 92-109.

Strike, V., Gao, J., Bansal, P. (2006). "Being good while being bad: Social Responsibility and the international diversification of US firms", Journal of International Business Studies, 37(6): 850-862.

Suchman, M. (1995). "Managing legitimacy: strategic and institutional approaches", Academy of Management Review, 20(3): 571-610.

Surroca, J., Tribò, J.A., Waddock S., (2010). "Corporate responsibility and financial performance: The role of intangible resources", Strategic Management Journal, 31: 463-490.

Thomas, M. (2001). "Asian corporates: Willing participants in the reporting devolution?", Corporate Environmental Strategy, 8(3): 248-259.

UNCTAD (2008). "2008 Review of the corporate responsibility performance of large emerging market enterprises," TD/B/C.II/ISAR/CRP.3.

Visser, W. (2008). Corporate Social Responsibility in developing countries. In: Crane, A., et al. (Eds.), The Oxford Handbook of Corporate Social Responsibility in Developing Countries. Oxford University Press, UK: 473-479.

Vives, A. (2012). "Is socially responsible investment possible in Latin America?", Journal of Corporate Citizenship, 48: 59-74.

Wooldridge, J. M. (2010). Econometric analysis of cross section and panel data, Harvard, MA: MIT Press.

Wright, M. (2008). "Corporations and Human Rights. A survey on the scope and patterns of alleged corporate-related human rights abuses," Harvard University Working Paper for the Corporate Social Responsibility Initiative, 44.

Zaheer, S. (1995). "Overcoming the liability of foreignness", Academy of Management Journal, 38(2): 341-363. 


\section{APPENDIX}

\section{LIST OF FIRMS INCLUDED IN THE STUDY WITH COUNTRY AND INDUSTRY SPECIFICATIONS}

\begin{tabular}{lll}
\hline FIRM & COUNTRY & INDUSTRY \\
\hline PetroChina & China & Extractive \\
ICBC & China & Banking \\
Sinopec-China Petroleum & China & Extractive \\
Bank of China & China & Banking \\
CCB-China Construction Bank & China & Banking \\
Fosun Property Holdings Ltd & China & Real Estate \\
China Telecom & China & TLC \\
Bank of Communications & China & Banking \\
Ping An Insurance Group & China & Banking \\
Baoshan Iron \& Steel & China & Steel \\
Lenovo & China & TLC \\
China Merchants Bank & China & Banking \\
Aluminum Corporation of China (Chinalco) & China & Steel \\
CLP Holdings & China & Electricity and other Utilities \\
China Citic Bank & China & Banking \\
Petrobras-PetroleoBrasil & Brazil & Extractive \\
Vale & Brazil & Steel \\
Banco do Brasil & Brazil & Banking \\
ItauUnibanco & Brazil & Banking \\
Eletrobras & Brazil & Electricity and other Utilities \\
Suzano & Brazil & Pulp and Paper \\
Tele Norte Leste & Brazil & TLC \\
MetalurgicaGerdau & Brazil & Steel \\
CSN-Cia Siderurgica & Brazil & Steel \\
Cemig & Brazil & Electricity and other Utilities \\
BRF-Brasil Food & Brazil & Food and Beverages \\
Sul America & Brazil & Electricity and other Utilities \\
Braskem & PharmaChem \\
Marfrig & Food and Beverages \\
Embraer & Berospace \\
\hline
\end{tabular}




\begin{tabular}{lll} 
Mahindra Satyam & India & TLC \\
Reliance Industries & India & Extractive \\
Wipro & India & TLC \\
State Bank of India Group & India & Banking \\
IndianOil & India & Extractive \\
Icici Bank & India & Banking \\
National Thermal Power Corporation (NTPC) & India & Electricity and other Utilities \\
Steel Authority of India & India & Steel \\
Tata Steel & India & Steel \\
Bharti Airtel & India & TLC \\
Tata Consultancy Svcs & India & TLC \\
Housing Development Finance Corporation & India & Banking \\
Larsen \& Toubro & India & Heavy Industry \\
Bharat Petroleum & India & Extractive \\
Infosys Technologies & India & TLC \\
Gazprom & Russia & Extractive \\
Lukoil Holding & Russia & Extractive \\
UES of Russia & Russia & Electricity and other Utilities \\
Sberbank & Russia & Banking \\
Rosneft (NK Rosneft' OAO) & Russia & Extractive \\
Surgutneftegas & Russia & Extractive \\
TNK-BP Holding & Russia & Extractive \\
MMC Norilsk Nickel & Russia & Steel \\
OAO Severstal & Russia & Steel \\
VTB Bank & Russia & Banking \\
Sistema JSFC & Russia & TLC \\
Uralkali & Russia & PharmaChem \\
Novolipetsk Steel (NLMK) & Russia & Steel \\
Tatneft & Extractive \\
VimpelCom & TLC \\
\hline
\end{tabular}




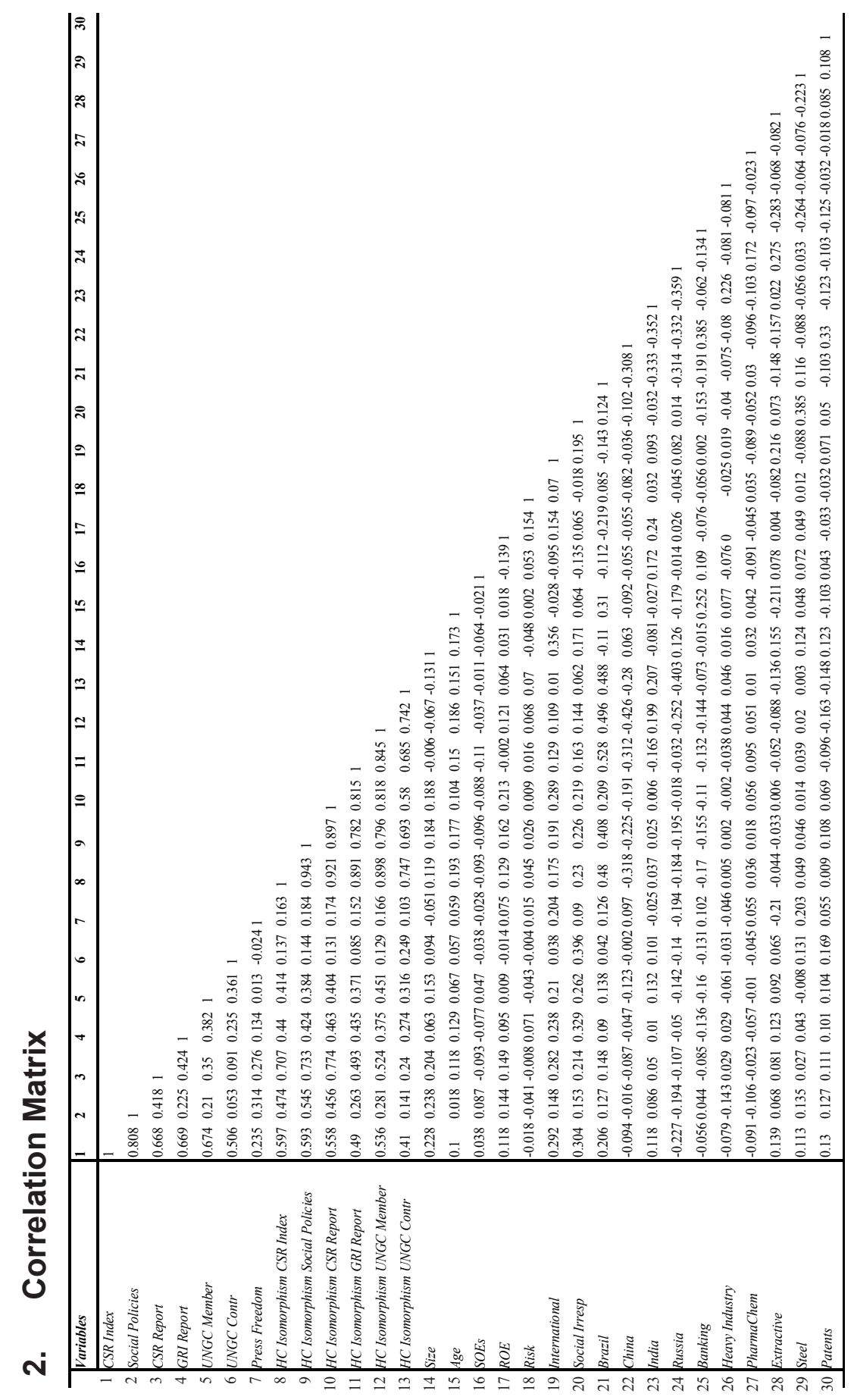




\section{Chinese agricultural overseas investment: trends, policies and CSR}

Kevin May**

This short paper examines three key questions. First, what are the major trends, characteristics and importance of Chinese outward foreign direct investment (OFDI) in the agricultural sector? Second, what is the position of the Chinese government on Chinese agricultural OFDI? Last, to what extent do Chinese policies promote responsible agricultural OFDI? The paper first shows that China has become a major global source of OFDI in the agricultural sector, and to a significant degree, the investment targets developing countries, especially the ASEAN countries. The amount of Chinese agricultural OFDI is very likely to grow rapidly in the coming years because of a range of factors, especially the active promotion of the investment by the Chinese government. The paper then shows that there is a range of discourse and policies that target Chinese OFDI in general but relatively few are specifically related to the agricultural sector. The policies contain rather few and limited provisions related to corporate social responsibility, especially in terms of transparency and accountability. Although some Chinese agricultural companies have started to publicly report about the social responsibility of their overseas investment, this does not seem widespread. Hence, there are significant challenges to overcome if Chinese agricultural OFDI and investing companies are to become a positive force of sustainable development. At the end, the paper provides some policy and research recommendations.

Key words: agricultural investment, China, corporate social responsibility

\section{Introduction}

In many developing countries, the majority of the poorest people live in rural areas, and depend on agriculture for their livelihoods. ${ }^{1}$ For example,

* The author would like to thank Lise Johnson and Kaitlin Cordes from the Vale Columbia Center on Sustainable International Investment of the Columbia University and also the two anonymous reviewers of the Transnational Corporations, for their meticulous reviews of and valuable inputs to this paper.

** Kevin May is the Manager of the China and the Developing World Programme of Oxtam Hong Kong.

${ }^{1}$ See World Bank (2008). 
in Zambia, agriculture provides livelihoods to more than 60 per cent of the population, and is also the main source of income and employment, employing approximately 60 per cent of the labour force, in 2013. ${ }^{2}$ Similarly, in both the Lao People's Democratic Republic and Myanmar, the agricultural populations and also the labour forces in the agricultural sector constitute more than half of the total populations and the total labour forces. ${ }^{3}$ In this regard, investment in the agricultural sector of these countries can present significant opportunities for development and poverty eradication, but can also pose new challenges. As such, it is an issue of vital importance for policymakers.

The United Nations estimated that in 2012 the total global stock of foreign direct investment (OFDI) which went to the sector of agriculture, hunting, forestry and fishing was only $\$ 81.7$ billion, less than 0.4 per cent of the total global stock of the investment in all sectors, which was $\$ 23.3$ trillion. ${ }^{4}$ Most of this international investment in agriculture, however, is going to developing countries: as of 2012, almost 72 per cent of the total global stock of agricultural OFDI (or roughly $\$ 58.8$ billion) was in developing countries. ${ }^{5}$

2 See FAOSTAT (available at http://faostat.fao.org). In 2013, the total population of Zambia was about 14.5 million, with agricultural population of 8.7 million. The total labour force of the country was about 5.8 million, with 3.5 million in the agricultural sector.

${ }^{3}$ See FAOSTAT (available at http://faostat.fao.org). In 2013, the total population of the Lao People's Democratic Republic was about 6.8 million, with agricultural population of 4.3 million. The total labour force of the country was about 3.6 million, with 2.7 million in the agricultural sector. In 2013, the total population of Myanmar was about 53.3 million, with agricultural population of 35.3 million. The total labour force of the country was about 31.7 million, with 20.9 million in the agricultural sector.

${ }^{4}$ Foreign direct investment (FDI) is defined as an investment involving a long-term relationship and reflecting a lasting interest and control by a resident entity in one economy (foreign direct investor or parent enterprise) in an enterprise resident in an economy other than that of the foreign direct investor (FDI enterprise or affiliate enterprise or foreign affiliate). FDI implies that the investor exerts a significant degree of influence on the management of the enterprise resident in the other economy.

5 See UNCTAD (2014). The United Nations estimated that between 2010 and 2012, the total global flows of foreign direct investment which went to the sector of agriculture, hunting, forestry and fishing were only $\$ 5.7$ billion, about 0.4 per cent of the total global flows of the investment in all sectors which were $\$ 1.5$ trillion. Nevertheless, it is also significant to highlight that 84.5 per cent of the total global flows of OFDI in the sector of agriculture, hunting, forestry and fishing went to developing countries in these three years, which were $\$ 4.8$ billion. 
Some contend that such foreign investment in developing countries' agricultural sector will increase, with the forces driving that trend including a growing demand for food and meat from emerging economies, increases in bio-fuel initiatives, efforts to meet energy security needs, depletion of natural resources (especially land and water) in other countries, volatile food prices, and agricultural commodity speculation. ${ }^{6}$ One of the countries that are expected to play a key role in pushing the increase in this investment is China.

FDI by China and others could play a positive role in agricultural development and poverty reduction and bring a range of benefits to poor farmers and local communities, including earnings increases, technology transfer, higher productivity, market access and job creation. However, experience has also shown that such investment carries the risk of forced evictions, depriving local communities of their land, increasing conflicts over land and water, distorting customary land tenure systems, compounding local governance issues, reducing the policy space for peasant-oriented agricultural policies and distorting markets towards increasingly concentrated agribusiness interests and trade. $^{7}$

Given its potentially transformative impacts on the lives and livelihoods of people tied to and dependent upon the agricultural sector in the developing world, this paper explores Chinese OFDI in that sector, and is divided into two main parts. The first part highlights and assesses the trends, characteristics and significance of Chinese agricultural OFDI. The second part traces and evaluates the policies of the Chinese government to support, promote and regulate Chinese agricultural OFDI and investors. The third part examines the extent to which they address the social, environmental, and economic impacts of that investment in the developing countries in which they are made. In addition, it also provides an overview of the studies which have attempted to look at the impacts of the investment. The paper concludes that there remain huge challenges to overcome if Chinese agricultural OFDI is to become a strong positive force of sustainable development and poverty reduction in its host countries, and provides some policy recommendations for tackling the challenges, as well as identifying some areas for further research and investigation.

6 FAO (2013).

7 ibid. 


\section{Chinese agricultural OFDI - amount, destination and future projections}

\section{Amount and destination}

According to the Chinese government, in 2013, the total flows and stock of Chinese OFDI in the sector of agriculture, forestry, husbandry and fisheries (AFHF) were about $\$ 1.8$ billion and $\$ 7.2$ billion (with agriculture $\$ 2.1$ billion) respectively. ${ }^{8}$ As a portion of Chinese OFDI, AFHF OFDI is relatively small, constituting 1.7 per cent and 1.1 per cent of the total flows and stock of Chinese OFDI, and ranking ninth and thirteenth in terms of the amount of flows and stock respectively. ${ }^{9}$ OFDI in agriculture alone (as opposed to AFHF more broadly), represents an even smaller amount.

However, while relatively low in comparison to Chinese investment in other industries, Chinese investment in agriculture is at relatively high levels when compared with agricultural OFDI from other countries. According to the United Nations Conference on Trade and Development (UNCTAD), in 2007, the total stock of Chinese OFDI in agriculture worldwide was approximately $\$ 1.2$ billion, constituting 11.7 per cent of the total global stock of the OFDI in AFHF, which was $\$ 10.3$ billion. ${ }^{10}$ Based on those figures, China ranked third in the world, behind only the United States (approximately $\$ 1.6$ billion) and Canada (approximately $\$ 1.4$ billion) as an outward investor in agriculture. ${ }^{11}$ Chinese OFDI in agriculture was also significantly greater than that of other developing countries and economies in transition. Behind China fell the Republic of Korea (roughly $\$ 300$ million (2005)), Croatia (roughly $\$ 200$ million (2006)), Chile (roughly $\$ 200$ million) and Brazil (roughly $\$ 100$ million). ${ }^{12}$ Chinese investment in agriculture alone constituted

8 See Ministry Of Commerce, People's Republic of China (2014: 137-138). Note that the separate figure on agricultural investment, originally embedded in the AFHF figures, is not available in the similar reports produced by the Ministry of Commerce in the previous years, except 2013.

${ }^{9}$ The other sectors include leasing and business service, finance, mining, wholesale and retail trade, manufacturing, transportation, storage and post, construction, real estate, production and supply of electricity, gas and water, scientific research, residents service, repair and other service, and information transmission, computer services and software. See Ministry Of Commerce, People's Republic of China (2014: 137-138).

10 See UNCTAD (2009: 219).

${ }^{11}$ See UNCTAD (2009: 118).

12 ibid. 
almost half of the total stock of OFDI in AFHF from all developing countries. ${ }^{13}$

According to another set of data about agricultural investment which, as defined, "covers all activities related to food, beverages and tobacco" between 2003 and 2011, the amount of Chinese OFDI flows to agriculture reached approximately $\$ 4.7$ billion, second only to Japan (roughly $\$ 6.3$ billion) in Asia, and remained the largest among developing countries and the BRICS (FAO, 2013). ${ }^{14}$ Another attempt to track foreign investment in agriculture and land globally also shows that China is one of the most active investors in terms of the size of the land that has reportedly been acquired by foreign investment. ${ }^{15}$

Much of that outward investment is in Asia and the Russian Federation. According to the Chinese government, in 2013, 29.9 per cent ( $\$ 543.3$ million) of the total Chinese AFHF OFDI flows and 22.2 per cent (\$1.6 billion) of the total Chinese AFHF OFDI stock were in the ASEAN countries, and 22.1 per cent (\$400.4 million) of total Chinese AFHF OFDI flows and 23.4 per cent ( $\$ 1.7$ billion) of total Chinese AFHF OFDI stock went to the Russian Federation. ${ }^{16}$ One reason behind this pattern appears to be proximity: most of these countries share borders with China. Beyond Asia, Chinese AFHF OFDI flows primarily to Australia and the United States.

${ }^{13}$ See UNCTAD (2009: 219).

14 Regarding the agricultural OFDI flows between 2003 and 2011, the United States remained the largest in the world, with about $\$ 29$ billion, followed by the United Kingdom (roughly $\$ 14.1$ billion), Switzerland (roughly $\$ 12$ billion), Germany (roughly $\$ 11$ billion), Netherlands (roughly $\$ 8$ billion), Japan (roughly $\$ 6.3$ billion), France (roughly $\$ 6$ billion). This set of data originally comes from the fDi Markets database.

15 It is reported that between 2000 and 2010, China has acquired approximately 3.6 million hectares of land while the United Kingdom, the United states, the United Arab Emirates, India, Egypt and the Republic of Korea 4.9, 4.2, 3.2, 2.1, 1.5 and 1.4 million hectares respectively. See official web site of the Land Matrix, <http://www. landmatrix.org/en/>. Another similar attempt, also based on published reports, estimates that up to 2012, China has reportedly acquired approximately 14 million hectors of land for agricultural production, with approximately 4.8 million hectares of which are confirmed by major media sources in China. See Smaller et al. (2012). It is important to note that some of these data have been questioned and challenged for its validity and completeness. See, for example, Bräutigam and Zhang (2013). This is understandable. As a matter of fact, very little information about OFDI in agriculture is made publicly available by investors and governments of both investing and host countries, such as exactly where and when the investors invest and also how much land they acquire and how they do so. This makes it extremely difficult to obtain a true and full picture about the nature, scale and characteristics of the investment.

${ }^{16}$ See Ministry Of Commerce, People's Republic of China (2014: 114 and 118). 
Table 1. Chinese AFHF OFDI flows and stock in most important countries and regions in 2013

(Millions of US dollars)

\begin{tabular}{lcc}
\hline Economy & $\begin{array}{c}\text { Chinese AFHF OFDI } \\
\text { flows }\end{array}$ & $\begin{array}{c}\text { Chinese AFHF OFDI } \\
\text { stock }\end{array}$ \\
\hline ASEAN $^{\text {a }}$ & 543.3 & 1597.1 \\
Russian Federation $^{\text {b }}$ & 400.4 & 1682.5 \\
Hong Kong (China) $_{\text {Australia }}$ & 259.8 & 553.8 \\
United States & 75.9 & 283.1 \\
\hline
\end{tabular}

Source: Ministry Of Commerce, People's Republic of China (2014).

a In 2013, the total stock of Chinese OFDI in the agricultural sector of the ASEAN was ranked eighth, among those in other sectors of the region.

b In 2013, the total stock of Chinese OFDI in the agricultural sector of the Russian Federation was the second largest, compared with those in other sectors of the country.

Data thus indicate that China has become one of the top sources of agricultural OFDI in the world, playing a particularly important role driving South-South links in the developing world. A significant portion of its investment has targeted developing countries, especially the ASEAN countries, where Chinese investment can be a large share of total agricultural FDI. For example, in the Lao People's Democratic Republic, more than 20 per cent of its agricultural OFDI stocks come from China. ${ }^{17}$ These trends, moreover, appear likely to both continue and intensify.

\section{On the rise}

Both the flows and stock of Chinese OFDI in the AFHF sector increased approximately twenty-one and twenty-two times from 2003 to 2013, with sharp spikes in 2009 and 2012 (the flows in 2009 doubled compared with those in 2008, and the flows almost doubled between 2011 and 2012).

17 It is estimated that between 2005 and 2011, total FDI stock of the Lao People's Democratic Republic in the agriculture and forestry sectors is about $\$ 1.1$ to $\$ 1.7$ billion. See Campbell et al. (2012). In addition, it is estimated that by 2011 the total Chinese agricultural OFDI in the Lao People's Democratic Republic was about $\$ 233$ million. See Onphanhdala and Suruga (2013: 11). 
Consistent with those trends, Chinese AFHF OFDI in the ASEAN and the Russian Federation has been on the rise, despite the fact that there was negative growth in the Chinese AFHF OFDI flows to the Russian Federation from 2010 to 2011 after a spike in 2010.

Table 2. Chinese AFHF OFDI flows and stock from 2003-2013

(Millions of US dollars)

\begin{tabular}{rrr}
\hline Year & Flows & Stock \\
\hline 2003 & 86.0 & 331.0 \\
2004 & 288.7 & 834.2 \\
2005 & 105.4 & 511.6 \\
2006 & 185.0 & 816.7 \\
2007 & 271.7 & 1206.1 \\
2008 & 171.8 & 1467.6 \\
2009 & 342.8 & 2028.4 \\
2010 & 533.9 & 2612.1 \\
2011 & 797.8 & 3416.6 \\
2012 & 1461.4 & 4964.4 \\
2013 & 1813.1 & 7179.1 \\
\hline
\end{tabular}

Source: Ministry Of Commerce, People's Republic of China (2004: 6, 2012: 40-41, 2014 : 137-138).

Table 3. Chinese AFHF OFDI flows and stock in the ASEAN and the Russian Federation, 2009-2013

(Millions of US dollars)

\begin{tabular}{ccccc}
\hline Year & $\begin{array}{c}\text { Chinese AFHF } \\
\text { OFDI flows to } \\
\text { ASEAN }\end{array}$ & $\begin{array}{c}\text { Chinese AFHF } \\
\text { OFDI stock in } \\
\text { ASEAN }\end{array}$ & $\begin{array}{c}\text { Chinese AFHF } \\
\text { OFDI flows } \\
\text { to Russian } \\
\text { Federation }\end{array}$ & $\begin{array}{c}\text { Chinese AFHF } \\
\text { OFDI stock } \\
\text { in Russian } \\
\text { Federation }\end{array}$ \\
\hline 2009 & 101.6 & 340.5 & 69.6 & 548.3 \\
2010 & 168.4 & 528.4 & 180.6 & 747.9 \\
2011 & 190.7 & 709.4 & 147.5 & 883.9 \\
2012 & 299.7 & 996.7 & 235.3 & 1280.5 \\
2013 & 543.3 & 1597.1 & 400.4 & 1682.5 \\
\hline
\end{tabular}

Source: Ministry Of Commerce, People's Republic of China (2010, 2011, 2012, 2013, 2014). 
A number of scholars and researchers studying the rising trend of Chinese agricultural OFDI contend that such investment is likely continue to increase and to do so even more rapidly in the coming times, especially in other developing countries. ${ }^{18}$ In brief, these predictions are mainly based on expected growth in demand for agricultural commodities. For one, as the population grows and urbanization accelerates, the demand for staple food such as rice, wheat and corn will rise. Moreover, the demand for other agricultural commodities such as soya beans, cotton, palm oil, dairy products, hides and skins, wool and rubber are also likely to increase. These agricultural goods are needed to supply the food processing and manufacturing industries, and the energy sector, with increases in consumption being primarily driven by the rising demand in China for meat and bio-fuels.

OFDI is important in this context as it will be difficult to fulfil these demands from domestic production in China in the longer term. China has very limited natural resources especially land and water. With only about 8 per cent of global farmland or arable land it now has to feed one-fifth of the world's population. ${ }^{19}$ Exacerbating this strain on resources, climate change has already negatively affected production and threatens to continue to do so. ${ }^{20}$ Thus, while food consumption has exceeded food production since 2008 , it is predicted that the gap will widen in the next decade. ${ }^{21}$

Another factor that may be driving Chinese agricultural OFDI is that reliance on trade to meet China's domestic needs is seen as presenting undesirable challenges. In particular, importing agricultural commodities, especially soya beans and cotton, from the international market has posed risks to China. ${ }^{22}$ The prices of the commodities have been rather volatile, and the global markets are very much controlled by global commodity traders such as ADM, Bunge, Cargill and (Louis) Dreyfus.

18 See Sun (2011), Smaller et al. (2012), Buckley (2012) and FAO (2013).

19 See FAOSTAT (available at http://faostat.fao.org). It is estimated that in 2012, the total arable land in the world was about 1.4 billion hectares while that in China about 0.1 billion hectares.

20 See OECD/FAO (2013: 65-66).

21 See OECD/FAO (2013: 69).

22 From 2001 to 2012, China's import dependence in agriculture doubled, and it is estimated that Chinese imports on agricultural commodities such as oilseeds and coarse grains will rise sharply in the next decade. See OECD/FAO (2013). 
Foreign investment, in contrast, can be a strategy for addressing those issues - enabling the country to secure access to natural resources, and mitigate disruptions and fluctuations in supply and price. There are abundant land and water resources in other developing countries, including the nearby ASEAN countries of the Lao People's Democratic Republic and Myanmar. And the regulatory environment in host countries is often conducive to enabling Chinese and other foreign entities to take advantage of opportunities for investment, imposing little controls or restrictions on foreign investment in the agricultural sector.

Those factors - growing demand, perceived benefits of internationalization over trade, and open investment climates in the host countries - support contentions that Chinese agricultural OFDI will increase and that Chinese firms will become more involved in the agricultural sector of other developing countries to grow the commodities such as soya beans and cotton they need for the expanding domestic Chinese market. ${ }^{23}$ But what is the position of the Chinese government?

\section{Central government}

The Chinese central government has had a stated policy stance on agricultural OFDI: it expressly supports the investment.

In 2001, the 9th National People's Congress (NPC) of the People's Republic of China formally adopted the "going out" strategy (zouchuqu zhanlue) as a national policy at its Fourth Session. ${ }^{24}$ Five years later, "agriculture going out" was expressly mentioned and formally adopted by the Chinese leaders as a national strategy. More specifically, in 2006, the Opinions of the Central Committee of the Communist Party of China and the State Council on Proactively Developing Modern Agriculture

${ }^{23}$ There are discussions about what factors have been driving Chinese OFDI in general and how. The drivers mentioned in the discussions include population growth, urbanisation, overcoming trade barriers, searching for new markets, change of monetary policies, acquiring natural resources, and obtaining brands, technology and managerial assets. See Rosen and Hanemann (2009), Macedo et al (2009), Zhang (2010), U.S.-China Economic and Security Review Commission (2011), Xing and Li (2011), World Wide Fund for Nature (2012) and Zha (2013).

24 2001年3月15日第九届全国人民代表大会第四次会议批准《国民经济和社 会发展第十个五年计划纲要》Chapter 17, Section 4. <http://www.people.com.cn/ GB/shizheng/16/20010318/419582.html> (only available in Chinese) 
and Solidly Promoting the Socialist New Countryside Construction was issued and proposed "to accelerate the implementation of the agriculture "going out" strategy". ${ }^{25}$ That initiative, however, mainly focused on agricultural trade, promoting imports and exports of agricultural commodities but not overseas investment. ${ }^{26}$

It was not until 2008, in the Decision of the Central Committee of the Communist Party of China on Several Important Issues on Promoting Rural Reform and Development, that the agricultural "going out" strategy was expressly noted as including the broader idea of "foreign agricultural cooperation". ${ }^{27}$ In the Chinese context, such international cooperation generally concerns foreign investment, apart from technology exchange, use of foreign capital, foreign trade and also aid. ${ }^{28}$ The Decision states that China should coordinate and develop foreign agricultural cooperation, foster activities of agricultural multinational enterprises, and establish an international system for the production, sales, processing, storage and transportation or logistics of agricultural commodities.

Two years later in 2010, the Chinese central government made it clear that it wanted to continue, and expand those efforts to promote Chinese overseas investment in the agricultural sector. The Suggestions of the Central Committee of the Communist Party of China on Making the Twelfth Five-Year Plan for National Economic and Social Development expressly states that China should "enlarge" agricultural

${ }^{25}$ State Council, 《中共中央国务院关于积极发展现代农业扎实推进 社会主义新农村建设的若干意见》中发〔2007) 1 号, 2006/12/31, Provision 5.3. <http://www.gov.cn/gongbao/content/2007/content_548921.htm> (only available in Chinese)

${ }^{26}$ State Council, 《中共中央国务院关于积极发展现代农业扎实推进 社会主义新农村建设的若干意见》中发(2007) 1号, 2006/12/31, Provision 5.3. <http://www.gov.cn/gongbao/content/2007/content_548921.htm> (only available in Chinese)

27 Central Committee Of The Communist Party Of China, 《中共中央关于推 进农村改革发展若干重大问题的决定》，2008年10月12日中国共产党第十七 届中央委员会第三次全体会议通过，2008/10/12， <http://news.xinhuanet.com/ newscenter/2008-10/19/content_10218932_1.htm> (only available in Chinese)

28 See Ministry Of Agriculture, 《农业国际合作发展 “十二五” 规划 (20112015年）》，2012/01/11，<http://www.moa.gov.cn/ztzl/shierwu/hyfz/201201/ t20120111_2454566.htm> (only available in Chinese) The development plan on agricultural international cooperation focuses on overseas investment, technology exchange, use of foreign capital, foreign trade and also aid. 
international cooperation. ${ }^{29}$ This requirement is repeated in the Twelfth Five-Year Plan for National Economic and Social Development, which was formally adopted by the 11th NPC of the People's Republic of China in $2011 .{ }^{30}$

\section{Ministries}

These central policies and calls for promoting and encouraging Chinese agricultural OFDI have been echoed in various respective Chinese ministries and reflected in their measures, plans and policies.

One of these important ministries is the National Development and Reform Commission (NDRC) which among others, is responsible for overseeing the imports of agricultural commodities such as food grains, cotton and sugar, and taking the lead in managing the state reserve of those commodities. ${ }^{31}$ In 2008, the NDRC issued the National Food Security Medium and Long-Term Plan Outline (2008-2020) which states in relevant part that China should "implement agriculture 'going out' strategy, encourage domestic companies to 'go out'". ${ }^{32}$

It is important to note that the NDRC expressly links food imports (including soya beans and edible vegetable oil) and food security with Chinese agricultural OFDI: the latter serves the former. Reflecting this point, the Plan Outline further states that China should "establish a system for ensuring stable and reliable sources of food imports, and increase the ability of ensuring domestic food security". ${ }^{33}$

There are indications, however, that China is sensitive about the reactions that may be generated by this strategy and ways through which it may be implemented. Upon the release of the Plan Outline,

${ }^{29}$ Central Committee Of The Communist Party Of China, 《中共中央关于制定国 民经济和社会发展第十二个五年规划的建议》，2010年10月18日中国共产党第十 七届中央委员会第五次全体会议通过，2010/10/18， <http://cpc.people.com.cn/GB/ 67481/94156/204933/206698/13109025.html> (only available in Chinese)

30 2011年3月14日第十一届全国人民代表大会第四次会议批准《国民经 济和社会发展第十二个五年计划纲要》Chapter 52, Section 2. <http://www.gov. $\mathrm{cn} / 2011 \mathrm{lh} /$ content_1825838_13.htm> (only available in Chinese)

${ }^{31}$ See official web site of the National Development and Reform Commission, $<$ http://en.ndrc.gov.cn/mfndrc/default.htm>

32 National Development And Reform Commission, 《国家粮食安全中长期规划 纲要 (2008-2020年)》, 2008, Section 4, Provision 3, <http://www.gov.cn/jrzg/200811/13/content_1148414.htm> (only available in Chinese)

33 ibid. 
for instance, the Deputy Minister of the NDRC, Mr. ZHANG Xiaoqiang expressly denied that the Chinese government intends to use largescale purchase or long-term leasing of other countries' land to grow food in large scale, and to rely on this to ensure food security in China. ${ }^{34}$

Another very important ministry concerning agricultural OFDI is the Ministry of Agriculture (MOA). In August 2006, the MOA issued the Eleventh Five-Year National Plan on Agriculture and Rural Economic Development, which for the first time expressly echoes the themes described above in such an important ministerial document but with very little elaboration on how to implement the agriculture "going out" strategy. ${ }^{35}$ In September 2011, the MOA issued the Twelfth FiveYear National Plan on Agriculture and Rural Economic Development. The Plan provides some general directions for the strategy and states that China should "increase support for agriculture 'going out'", "set up platforms for enterprises, expand agricultural foreign cooperation and exchange", and "continue to strengthen agricultural international cooperation". ${ }^{36}$ Consistent with that plan, in 2011, the MOA signed with the China Development Bank (CDB) a memorandum of understanding which aims to support agriculture 'going out' together through funding research and pilot projects. ${ }^{37}$

It is important to note that unlike the NDRC, the MOA has not linked food security in China with Chinese agricultural OFDI, at least not in its formal or official documents. Indeed, in 2009, Mr. NIU Dun, a Deputy Minister of the MOA stated that China "cannot rely on [investment in] other countries for our own food security" and "we have to depend on ourselves". ${ }^{38}$ But again, there appear to be contradictory

\footnotetext{
${ }^{34}$ See ZHANG Xiaoqiang's reply to a journalist from the Voice of America at a press conference, 2008/11/13, <http://www.gov.cn/wszb/zhibo280/content_1147864.htm> (only available in Chinese)

35 MOA, 《全国农业和农村经济发展第十一个五年规划》, 农计发[2006]21 号, August 2006, <http://www.moa.gov.cn/zwllm/zwdt/200608/t20060803_660523. $\mathrm{htm}>$ (only available in Chinese)

${ }^{36} \mathrm{MOA}$, 《全国农业和农村经济发展第十二个五年规划》，农计发[2011]9号， September 2011, Chapter 6, Section 6, <http://www.moa.gov.cn/ztzl/shierwu/> (only available in Chinese)

$37 \mathrm{MOA}$, 《全国农业和农村经济发展第十一个五年规划》，农计发[2006] 21 号, August 2006, <http://www.moa.gov.cn/zwllm/zwdt/200608/t20060803_660523. htm > (only available in Chinese)

38 Financial Times, "China rules out pursuit of Africa farmland", 2009/04/21, <http://www.ft.com/cms/s/0/f03643dc-2e0a-11de-9eba-00144feabdc0.html>
} 
voices: for instance, Mr. WAN Baorui, a former Deputy Minister of the MOA (1993-2001), a former member of the Agriculture and Rural Affairs Committee of the National People's Congress (2003-2008), and currently the Director of the State Food and Nutrition Consultant Committee, has been advocating agriculture 'going out' since 2006. ${ }^{39}$ Recently, he said that agriculture 'going out' is 'inevitable' if China is to guarantee the stable supply of agricultural commodities, because of the accelerating pace of urbanization, limited natural resources like farmland and water, and also serious problems of environmental pollution caused by agriculture, in China. ${ }^{40}$

Officials of the Ministry of Commerce (MOFCOM) have also expressly supported the importance of agriculture going out on various public occasions. As early as 2004, Mr. ZHANG Zhigang, the then Deputy Minister, proclaimed that one of the main directions of 'going out ' was to "develop overseas agricultural cooperation". ${ }^{41}$

In terms of the commodities prioritized for overseas investment, soya beans are frequently cited as an example of concern. ${ }^{42}$ The use of soya beans as an important animal feed and bio-fuel feedstock has upped demand for that commodity due to rising domestic meat consumption and energy needs. Whereas China was once the largest exporter of that crop, it is now its largest importer. ${ }^{43}$

In summary, the Chinese government, both at the legislative and the ministerial levels, has set a clear mandate to endorse, support

39 WAN Baorui, “我国农业发展的新趋势”, People's Daily, 2006/12/29, <http:// theory.people.com.cn/BIG5/41038/5228178.html> (only available in Chinese)

40 WAN Baorui, “加快实施农业'走出去'战略'走出去'战略”, People's Daily, 2012/10/26, <http://finance.sina.com.cn/nongye/nyhgjj/20120605/080612224215. shtml> (only available in Chinese)

41 See ZHANG Zhigang's speech at the International Forum which was held on 2004/05/26 in Beijing, <http://news.xinhuanet.com/zhengfu/2004-05/27/ content_1492811.htm> (only available in Chinese)

42 See ZHANG Xiaoqiang's reply to a journalist from the Voice of America at a press conference, 2008/11/13, <http://www.gov.cn/ wszb/zhibo280/content_1147864.htm> (only available in Chinese) See also WAN Baorui, “加快实施农业 “走出去” 战略”, People's Daily, 2012/10/26, <http://finance.sina.com.cn/nongye/nyhgjj/20120605/080612224215.shtml> (only available in Chinese)

${ }^{43}$ See FAO. FAOSTAT (available at http://faostat.fao.org). Rome. In 2010, China imported about 57 million tonnes of soya beans, compared to about 30 million tonnes in 2006. 
and drive agricultural overseas investment, among others, to provide a relatively stable supply of agricultural commodities including, in particular, soya beans. There seems, however, to nevertheless be some divergence among Chinese leaders and government officials about China's professed food self-sufficiency policy and the role of OFDI in meeting future food security.

\section{What companies to support?}

The Chinese companies which the Chinese government targets in its agriculture "going out" strategy are large enterprises.

In 2010, Mr. HAN Changfu, the Minister of the MOA, said "large enterprises should be the main force of agriculture 'going out'". ${ }^{44}$

Similarly, in September 2011, the MOA issued the Twelfth FiveYear National Plan for State Farm Enterprises Economic and Social Development (2011-2015) which states that China should "encourage and guide state farm enterprises (SFEs) to 'go out', [and] forcefully start foreign agricultural cooperation". ${ }^{45}$

In 2012, the State Council (SC) issued the Opinions of Supporting Agricultural Industrialization Leading Agricultural Enterprises Development declaring that China should "provide convenience for the customs clearance of the domestically produced materials and facilities which are needed for the foreign investment projects of leading agricultural enterprises (LAEs)" ${ }^{46}$ Also in 2012, the NDRC issued the Twelfth Five-Year National Plan on Rural Economic Development which states that China should "proactively foster agricultural multi-national

44 华尔街日报：“中国农业部长：农业企业应该走出去”， 2010/12/28， <http://cn.wsj.com/GB/20101228/BCH001326.asp> (only available in Chinese)

45 MOA， 《全国农垦经济和社会发展第十二个五年规划（2011-2015年）

》, September 2011, Chapter 3, Section 5, Provision 1, <http://www.moa.gov.cn/ztzl/ shierwu/hyfz/201110/t20111018_2364044.htm> (only available in Chinese)

46 State Council, 《国务院关于支持农业产业化龙头企业发展的意见》，国发

(2012) 10号, Section 8, Provision 23, 2012/03/06, <http://www.gov.cn/zwgk/201203/08/content_2086230.htm> (only available in Chinese) 
enterprises", and "encourage large enterprise groups, SFEs, [and] LAEs" to invest overseas. ${ }^{47} 4849$

As summarized in Table 4, these moves by the Chinese government to drive agricultural OFDI make it particularly timely and important to explore whether such investment by Chinese enterprises, especially SFEs and LAEs, will likely become a positive force for the sustainable development of and poverty reduction in their recipient countries. These issues are particularly relevant and crucial to other developing countries such as the ASEAN countries, most of which, as shown above, have been targeted by Chinese investment and in which Chinese agricultural FDI can be a significant share of total investment in agriculture.

\section{Responsible Chinese Agricultural OFDI}

China has been praised for its agricultural sector's role in domestic poverty reduction..$^{50}$ The Chinese government has conducted a number of reforms in the rural areas which included relatively equitable land distribution, complete rescindment of agricultural taxes, and investment in infrastructure, supplemented with robust poverty alleviation programmes in those areas. Could we expect similar efforts, policies and successes for Chinese agricultural OFDI in other developing countries? How likely is it that the investment will bring positive impacts for the development of these countries? Does the Chinese government provide any guidelines, policies or regulations to promote positive

\footnotetext{
${ }^{47}$ National Development And Reform commission, 《全国农村经济发展 “十二 五” 规划》, June 2012, Chapter 7, Section 4, Provision 2, <http://www.sdpc.gov.cn/ zcfb/zcfbtz/2012tz/W020120806519571547020.pdf> (only available in Chinese)

${ }^{48}$ State farms enterprises are owned and were set up by the Chinese government originally for land reclamation in remote areas like Xinjiang and Heilongjiang.

${ }^{49}$ Leading agricultural enterprises, also known as "dragon heads", are companies which the Chinese government chooses for providing with supports such as loans and tax rebates, with the aim of encouraging the companies to invest in smallholder farmers and thus bringing economic benefits to them. See State Council, 《中共中央、国务 院关于1998年农业和农村工作意见》中发〔1998〕2号，1998/01/24. The MOA is responsible for selecting and monitoring leading agricultural enterprises. Unlike state farms enterprises, some leading agricultural enterprises are private companies while some are public ones. Some state farms are leading agricultural enterprises. In 2013, there are more than 110,000 leading agricultural enterprises in China.
}

${ }^{50}$ FAO (2012a: 51). 


\section{Table 4. The evolution of China's agricultural 'go out' key}

policies and discourse, 2014

\begin{tabular}{|c|c|c|c|}
\hline Year & $\begin{array}{c}\text { Government } \\
\text { body }\end{array}$ & Document & Key developments \\
\hline 2006 & $\mathrm{SC}$ & $\begin{array}{l}\text { Opinions of the Central } \\
\text { Committee of the Communist } \\
\text { Party of China and the } \\
\text { State Council on Proactively } \\
\text { Developing Modern } \\
\text { Agriculture and Solidly } \\
\text { Promoting the Socialist New } \\
\text { Countryside Construction }\end{array}$ & $\begin{array}{l}\text { Raised agriculture "going } \\
\text { out" strategy with main } \\
\text { focus on trade, imports } \\
\text { and exports of agricultural } \\
\text { commodities }\end{array}$ \\
\hline 2006 & MOA & $\begin{array}{l}\text { Eleventh Five-Year National } \\
\text { Plan on Agriculture and Rural } \\
\text { Economic Development }\end{array}$ & $\begin{array}{l}\text { Supported agriculture "going } \\
\text { out" strategy }\end{array}$ \\
\hline 2008 & $\begin{array}{l}\text { Central } \\
\text { Committee of } \\
\text { the Communist } \\
\text { Party }\end{array}$ & $\begin{array}{l}\text { Decision of the Central } \\
\text { Committee of the Communist } \\
\text { Party of China on Several } \\
\text { Important Issues on } \\
\text { Promoting Rural Reform and } \\
\text { Development }\end{array}$ & $\begin{array}{l}\text { Included foreign agricultural } \\
\text { cooperation in agriculture } \\
\text { "going out" strategy }\end{array}$ \\
\hline 2008 & NDRC & $\begin{array}{l}\text { National Food Security } \\
\text { Medium and Long-Term Plan } \\
\text { Outline (2008-2020) }\end{array}$ & $\begin{array}{l}\text { Supported agriculture } \\
\text { "going out" strategy and } \\
\text { encouraged domestic } \\
\text { companies to invest abroad }\end{array}$ \\
\hline 2010 & $\begin{array}{l}\text { Central } \\
\text { Committee of } \\
\text { the Communist } \\
\text { Party }\end{array}$ & $\begin{array}{l}\text { Suggestions of the Central } \\
\text { Committee of the Communist } \\
\text { Party of China on Making } \\
\text { the Twelfth Five-Year Plan for } \\
\text { National Economic and Social } \\
\text { Development }\end{array}$ & $\begin{array}{l}\text { Supported enlarging } \\
\text { agricultural international } \\
\text { cooperation }\end{array}$ \\
\hline 2011 & NPC & $\begin{array}{l}\text { Twelfth Five-Year Plan for } \\
\text { National Economic and Social } \\
\text { Development }\end{array}$ & $\begin{array}{l}\text { Supported enlarging } \\
\text { agricultural international } \\
\text { cooperation }\end{array}$ \\
\hline 2011 & MOA & $\begin{array}{l}\text { Twelfth Five-Year National } \\
\text { Plan on Agriculture and Rural } \\
\text { Economic Development }\end{array}$ & $\begin{array}{l}\text { Supported more support for } \\
\text { and expansion of agricultural } \\
\text { international cooperation } \\
\text { and also encouraged SFEs to } \\
\text { invest abroad }\end{array}$ \\
\hline 2012 & SC & $\begin{array}{l}\text { Opinions of Supporting } \\
\text { Agricultural Industrialization } \\
\text { Leading Agricultural } \\
\text { Enterprises Development }\end{array}$ & $\begin{array}{l}\text { Encouraged LAEs to invest } \\
\text { abroad }\end{array}$ \\
\hline 2012 & NDRC & $\begin{array}{l}\text { Twelfth Five-Year National } \\
\text { Plan on Rural Economic } \\
\text { Development }\end{array}$ & $\begin{array}{l}\text { Encouraged large enterprise } \\
\text { groups, SFEs and LAEs to } \\
\text { invest abroad }\end{array}$ \\
\hline
\end{tabular}

Source: Author's research. 
impacts of foreign investment such as job creation, increased incomes, skills transfer, respect and protection of local people's, workers', and women's rights, and protection of natural resources (especially land and water)? Does the government put in place any concrete initiatives or incentives to promote, support and monitor the corporate social responsibility (CSR) of its firms' investment?

Closely examined, there is a range of official documents and discourse of the Chinese government encouraging good policies and practices of Chinese companies investing overseas. In 2006, for instance, the State Council issued the Opinions of Encouraging and Standardising Outward Investment Cooperation, which contains nine guiding principles for Chinese overseas investment. ${ }^{51}$ The first principle stresses "mutual benefit" in and "win-win cooperation" with host countries. The fifth principle requires the Chinese investors "to abide by local laws and regulations, to insist on the openness, fairness and transparency of contracting projects, to keep promises, to fulfil the necessary social responsibility, to protect the legitimate rights and interests of local employees, to pay attention to environmental resource protection, and to care for and give support to the livelihoods of local community". The seventh principle then stresses the importance of "strengthening safety training" and "improving safe production responsibility system". These broad and general principles are repeated in at least two other important Chinese central government documents. The 2010 Suggestions of the Central Committee of the Communist Party of China on Making the Twelfth Five-Year Plan for National Economic and Social Development expressly states that China should "proactively start project cooperation which is beneficial to the improvement of local livelihoods". ${ }^{22}$ In addition, the 2011 Twelfth Five-Year Plan for National Economic and Social Development, expressly states that project cooperation should also "fulfil social responsibility" and "benefit the well-being of local people". ${ }^{53}$

51 State Council, 《关于鼓励和规范我国企业对外投资合作的意见》，October 2006, <http://www.gov.cn/ldhd/2006-10/25/content_423660.htm> (only available in Chinese)

${ }^{52}$ Central Committee Of The Communist Party Of China, 《中共中央关于制定国 民经济和社会发展第十二个五年规划的建议》，2010年10月18日中国共产党第十 七届中央委员会第五次全体会议通过，2010/10/18，<http://cpc.people.com.cn/GB/ 67481/94156/204933/206698/13109025.html> (only available in Chinese)

53 2011年3月14日第十一届全国人民代表大会第四次会议批准《国民经济和社 会发展第十二个五年计划纲要》Chapter 52, Section 2. <http://www.gov.cn/2011lh/ 
Also relevant, in 2008, the State Council issued the Management Measures for International Contractors which state, in relevant part, that Chinese contractors should "comply with the laws of the countries or regions where the projects are located", "uphold contracts", "respect local customs and habits", "stress ecological and environmental protection", "promote local economic and social development", and "not be engaged in commercial bribery". ${ }^{44}$

These broad and general principles are also repeated and reflected in a significant number of Chinese ministerial documents and statements. For instance, in 2006, the NDRC issued the Guiding Policy for Industries Investing Overseas, jointly with other ministries, which states that Chinese enterprises should "uphold the principles of mutual benefits and win-win" outcomes, and "abide by local laws and regulations". ${ }^{55}$

Similarly, Mr. ZHANG Zhigang, a former Deputy Minister of the MOFCOM, said that Chinese investors should "transfer Chinese practical technology", and increase "local employment", "local people's income", "local government taxation revenue", "local economy self-development ability", and "export ability", when he wrote about Chinese overseas cooperation in resources development in $2004 .{ }^{56}$ In 2006, Mr. CHEN Jian, a Deputy Minister of the MOFCOM also said at an international forum on Chinese enterprises" "going out" that Chinese enterprises" abilities to fulfil social responsibilities "should be enhanced". ${ }^{57}$

In 2006, the MOFCOM issued, together with the All-China Federation of Industry and Commerce (ACFIC), for public consultation, the Opinions of Encouraging and Supporting Privately Owned

content_1825838_13.htm> (only available in Chinese)

54 State Council, 《对外承包工程管理条例》，国务院令第527号, 2008/09/01, Articles 4 \& 12, <http://www.gov.cn/flfg/2008-07/28/content_1058146.htm> (only available in Chinese)

55 NDRC, MOFCOM, MOFA, MOF, General Administration of Customs, State Administration of Taxation and SAFE, 《境外投资产业指导政策》，发改外资 [2006]1312号，2006/07/05, Article 2, <http://www.zjkjt.gov.cn/news/node18/ detail180202/2007/180202_10785.htm> (only available in Chinese)

56 《经济工作通讯》2004年 第11期 2 页 5-6页, <http://www.cqvip.com/Read/ Read.aspx?id=10056295> (only available in Chinese)

57 “商务部部长助理陈健：开展跨国投资 促进互利共赢”，2006/04/28, <http://mnc.people.com.cn/BIG5/54823/4338767.html> (only available in Chinese) 
Enterprises "Going Out" (Draft) which expressly states that enterprises should have the "awareness of social responsibility", "comply with the laws and regulations of the countries where they are hosted", "respect local customs and habits", and "realize common development through mutually beneficial cooperation". 58

In 2009, the MOFCOM issued the Management Measures for Overseas Investment, similarly expressly stating that Chinese enterprises should "earnestly understand and comply with the relevant domestic and foreign laws, regulations and policies, and follow the principles of 'mutual benefits and win-win'". ${ }^{59}$ These principles and requirements and others such as CSR and environmental protection, have further been raised, discussed and endorsed at least two important meetings of the ministry. ${ }^{60}$

Moreover, in 2010, the MOFCOM issued the Regulations on Safety Management of Overseas Chinese-funded Enterprises and their Employees, jointly with a great number of other Chinese ministries. These regulations require Chinese enterprises investing overseas to "earnestly fulfil social responsibilities, perform well in environmental protection, tackle local employment, and active participate in public welfare undertakings". ${ }^{61}$ Echoing these instructions, in 2011, the MOFCOM and the State-owned Assets Supervision and Administration Commission (SASAC) signed an MOU and agreed to jointly promote the "social responsibility" of state-owned enterprises (SOEs) which invest overseas, among other things. ${ }^{62}$

58 MOFCOM and ACFIC, 《关于鼓励和支持民营企业“走出去”的若干意见》 (征求意见稿), 2006/02/28, <http://www.mofcom.gov.cn/aarticle/b/g/200604/ 20060401829430.html> (only available in Chinese)

59 MOFCOM, 《境外投资管理办法》，商务部令2009年第5号，2009/03/16， Article 3, <http://www.mofcom.gov.cn/aarticle/b/c/200903/20090306103210.html> (only available in Chinese)

60 See MOFCOM, 《关于2010年全国对外投资合作工作的指导意见，2010/02/26， <http://www.mofcom.gov.cn/aarticle/b/bf/201003/20100306810296.html>(only available in Chinese). See also MOFCOM, 《商务部确定“十二五”时期对外投资合作 发展主要任务和重点工作》，2010/02/26， < http://www.gov.cn/gzdt/2012-05/15/ content_2137815.htm> (only available in Chinese)

${ }^{61}$ MOFCOM, MOFA, NDRC, Ministry Of Public Security, SASAC, State Administration Of Work Safety, and ACFIC, 《境外中资企业机构和人员安全管理规定》，商合发 (2010) 313号, 2010/08/13, Chapter 3, Article 9, <http://www.mofcom.gov.cn/ aarticle/b/bf/201008/20100807087099.html > (only available in Chinese)

62 See “商务部和国资委联合召开 “加强对外投资合作和援外工作管理座谈会”, 2011/08/23， <http://www.mofcom.gov.cn/article/ae/ai/201108/20110807707765.shtml＇ 
All of these principles are relevant to and important in promoting responsible Chinese OFDI. They are, however, rather broad, contain little guidance in terms of practical application, and may be challenging to translate from policy to practice. But this may be changing as there are a growing number of Chinese government initiatives that provide more substantive and sector-specific based guidance on how Chinese companies could invest in a responsible manner.

In 2009, for instance, the State Forestry Administration (SFA), together with the MOFCOM, issued A Guide on Sustainable Overseas Forests Management and Utilization by Chinese Enterprises. The Guide expressly states that when managing and utilizing the forest resources in foreign countries, Chinese enterprises should "strictly observe [local] laws, regulations and policies", "make positive efforts to promote the local economic and community development, and conduct cooperation on the basis of mutual benefit", "highly value the ecological benefits of forests, and ensure the unification of ecological, economic and social benefits", "act in accordance with the government guidance and industry regulations", "play a positive role in sustainable development of local forests, and safeguard local ecological and environmental security", and "save the forest, land and energy resources to the greatest possible extent". The Guide also provides detailed and practical guidelines in the areas of legal compliance, management and utilization of forest resources, ecological protection, and community development. ${ }^{63}$

In 2012, the China International Contractors Association (CHINCA) released the Guide on Social Responsibility for Chinese International Contractors. The Guide covers a wide range of areas including information disclosure, occupational health and safety, labour rights, environmental protection, local stakeholders" engagement and community development, and provides specific and practical guidelines

(only available in Chinese)

See “商务部、国资委共同签署协作备忘录”，2011/08/23，<http://www.sasac.gov.cn/ $\mathrm{n} 1180 / \mathrm{n} 1566 / \mathrm{n} 258237 / \mathrm{n} 258869 / 13786005$.html $>$ (only available in Chinese)

${ }^{63}$ SFA and MOFCOM，《中国企业境外森林可持续经营利用指南》，March 2009, Section 2, <http://www.forestry.gov.cn/portal/main/s/224/content-401396.html> (only available in Chinese) 
on how Chinese enterprises should uphold CSR in these areas when they operate overseas contracting projects. ${ }^{64}$

More recently, in 2013, the MOFCOM and the Ministry of Environmental Protection (MEP) jointly issued the Environmental Protection Guide on Outward Investment Cooperation, specifically proposing that Chinese companies should obtain "concerned local environmental protection permits", conduct "environmental impact assessments", monitor "pollutant emission", protect "biodiversity", adopt "clean production", implement "green procurement", publish "environmental information", and communicate with local stakeholders including "local government environmental departments" and "local communities". ${ }^{65}$

Each of these initiatives is important in providing more practical principles and guidelines for Chinese companies on how to promote responsible overseas investment. However, compliance with them is only voluntary in nature and none of them contains any grievance or complaint system. Very little is known about how effective these guidelines are and what are the impacts they have actually brought. In comparison, some measures governing financial support of overseas projects are stronger.

The China Export and Import (EXIM) Bank, for example, has been relatively active on these issues. In 2007 it released its Guidelines for Environmental and Social Impact Assessments of the China (EXIM) Bank Loan Projects, requiring offshore projects to conduct "environmental and social impact assessments", "respect local people's rights to land and resources", and "properly handle resettlement problems". ${ }^{66}$ Then in 2011, the China EXIM Bank built on its earlier efforts by issuing the Environmental Assessment Framework and the Resettlement

${ }^{64}$ See CHINCA, 《中国对外承包工程行业社会责任指引》, September 2012, <http://images.mofcom.gov.cn/hzs/accessory/201209/1348819602840.pdf> (only available in Chinese)

${ }^{65}$ MOFCOM and MEP, 《对外投资合作环境保护指南》，商合函〔2013〕74 号, 2013/02/18, <http://www.mofcom.gov.cn/article/b/bf/201302/20130200039930. shtml> (only available in Chinese)

${ }^{66}$ China EXIM Bank, 《中国进出口银行贷款项目环境与社会评价指导意见》， 2007/08/28, Chapter 2. (only available in Chinese) 
Framework, providing detailed and practical guidance and requirements on how the assessments should be conducted. ${ }^{67}$

A more recent example of measures linking issues of sustainability to financial support is the initiative of the China Banking Regulatory Commission (CBRC), which issued its Green Credit Guidelines in 2012. These guidelines require banking institutions to strengthen the environmental and social risk management for overseas projects to which credit will be granted, and to ensure that sponsors of the projects will comply with the relevant laws and regulations on environment, land, health, safety and other relevant issues of the country and region where the projects are situated. The banking institutions are also to be publicly committed to applying related international norms or international standards to the projects, and to ensuring that the projects will be implemented in accordance with good international practices. ${ }^{68}$

These instruments are very important as Chinese companies have to comply with them when seeking financial support such as loans and credits from Chinese banks to invest overseas. ${ }^{69}$

\section{Agricultural Sector}

A question left open by the policies and initiatives described above is whether and to what extent the ministries, especially the NDRC and the MOA, which are mainly responsible for promoting and implementing the agriculture "going out" strategy, have promoted CSR principles or issued any sector-specific, practical guidelines, policies or regulations to implement them.

Notably, the NDRC does not appear to mention any broad principles such as CSR in its official policies, plans and documents concerning Chinese agricultural OFDI. And although the MOA's

${ }^{67}$ See China EXIM Bank, 《环境影响评价框架》, 2011, <http://www.eximbank. gov.cn/gonggaoarticle/notice/201101/11151_1.html>, and 《移民安置政策框架》， 2011, <http://www.eximbank.gov.cn/gonggaoarticle/notice/201101/11153_1.html> (only available in Chinese)

68 CBRC, 《绿色信贷指引》，银监发〔2012) 4 号, 2012/02/24, Chapter 4, provision 21, <http://www.cbrc.gov.cn/chinese/home/docView/127DE230BC31468B9 329EFB01AF78BD4.html> (only available in Chinese)

69 In 2012, the total loans which the China Export and Import Bank made was more than one trillion yuan. See China Export and Import Bank (2013). 
documents about Chinese agricultural OFDI do contain references to some relevant broad principles, they do not expand upon them or how they apply to agricultural OFDI. More specifically, the MOA's Twelfth Five-Year National Plan on Agriculture and Rural Economic Development states that China should realize "mutual benefits and win-win" in investing overseas in the agricultural sector but does not elaborate further. ${ }^{70}$ Similarly, the MOA's the Twelfth Five-Year Plan on Agricultural International Cooperation Development (2011-2015) issued in 2012 simply states that in the past China has been "encouraging and supporting capable, experienced, credible enterprises to 'go out'". ${ }^{71}$ It thus seems that, in contrast to the SFA, the MOA has not developed any concrete initiatives and guidelines aimed at operationalizing its broad principles regarding overseas investment.

Yet that may change. In 2011, the MOA and the China Development Bank signed an MOU through which they agreed to allot $\$ 420$ million to support agriculture 'going out ${ }^{72}$ Given that the bank has expressly put a significant degree of emphasis on the importance of CSR, one might expect that the bank would build a link between this outward investment fund and CSR. ${ }^{73}$ Nevertheless, it is not publicly known exactly how this fund will be spent and whether there is any requirement on evaluation and impact assessment of the Chinese agricultural companies to be supported by this fund, like those developed by the EXIM Bank.

More recently, in 2014, the MOA's think tank, the Research Center for Rural Economy (RCRE), has released a research report about Chinese agricultural overseas investment which shows that none of the

$70 \mathrm{MOA}$, 《全国农业和农村经济发展第十二个五年规划》, 农计发[2011]9号, September 2011, Chapter 6, Section 6, <http://www.moa.gov.cn/ztzl/shierwu/> (only available in Chinese)

71 MOA, 《农业国际合作发展“十二五”规划（2011-2015年）》，2012，Chapter 1， Section 2, <http://www.moa.gov.cn/ztzl/shierwu/hyfz/201201/t20120111_2454566.htm> (only available in Chinese)

72 See “农业部与国家开发银行签署《规划合作备忘录》”, 2011/02/08, <http:// www.gov.cn/gzdt/2011-02/18/content_1806106.htm> (only available in Chinese)

${ }^{73}$ The China Development Bank has been a member of the Global Compact since 2006, and has been an active participant. See the official web site of the United Nations Global Compact: <http://www.unglobalcompact.org/participant/2054-ChinaDevelopment-Bank> It has also produced social responsibility report annually since 2007. See the official web site of the bank: <http://www.cdb.com.cn/english/Column. asp?Columnld=190> 
interviewed Chinese companies releases any CSR report in their host countries. In response, the RCRE recommends, among others, that the financial support which the Chinese government provides for the investing companies should be closely linked with their CSR reporting. This is encouraging but of course, it remains to be seen whether this recommendation will be adopted and turned into policy by the authority. ${ }^{74}$

\section{Specific types of companies}

One route through which CSR issues may penetrate Chinese enterprises engaged in agricultural FDI is through government initiatives promoting CSR of LAEs operating in China, which are also supported by the agriculture "going out" strategy. Although these initiatives have a domestic focus, they could impact performance of LAEs overseas through greater awareness of CSR within the companies or explicit extension of the initiatives to foreign investment.

One relevant initiative came through the MOA's 2010 revisions to its Management Measures for Identifying National Priority Leading Agricultural Enterprises under Agricultural Industrialization and Monitoring their Operations, which incorporated the term "social responsibility". Among other things, the Measures encourage companies applying for LAE status to uphold corporate social responsibility and report on how their operations benefit rural households. LAEs are also to accept public supervision to monitor compliance. ${ }^{75}$

A second notable example is the issuance in 2012 of the Opinions of the State Council on Supporting the Development of Leading Agricultural Enterprises under Agricultural Industrialization. That text expressly calls for "strengthening the LAEs' awareness of social responsibility" and "step-by-step establishing CSR reporting system" of the companies. ${ }^{76}$

74 See Economic Information Daily, “农研中心建议加强顶层设计推进对外农业 投资”，2014/03/13，<http://dz.jjckb.cn/www/pages/webpage2009/html/2014-03/13/ node 53. htm $>$ (only available in Chinese)

${ }^{75} \mathrm{MOA}$ ，《农业产业化国家重点龙头企业认定和运行监测管理办法》农经发 [2010]11 号，2010/09/19， <http://www.chinatax.gov.cn/n8136506/n8136563/n8193451/ n9717203/n9717233/11217079.html> (only available in Chinese)

76 State Council, 《国务院关于支持农业产业化龙头企业发展的意见》国发 (2012) 10号, 2012/03/06, Chapter 7, Article 21. <http://www.gov.cn/zwgk/201203/08/content_2086230.htm> (only available in Chinese) 
There seems no such initiative, guideline or requirement in general to promote CSR, accountability and transparency of SFEs in China. It is, however, important to note that some SFEs are LAEs. ${ }^{77}$ For example, the Guangdong Guangken Rubber Group Company Limited is both an SFE and LAE, and has been investing overseas, especially in Southeast Asia. ${ }^{78}$ Therefore, the CSR initiatives regulating LAEs may have an impact among these companies.

In addition, it is also important to highlight that all SFEs and some LAEs are SOEs. For example, the China National Agricultural Development Group Corporation (CNADC) is an SOE and one of its subsidiaries, the China State Farms Agribusiness (Group) Corporation (CSFAGC) has been heavily investing overseas, especially in Africa. ${ }^{79}$ There is initiative to promote CSR of SOEs operating in China. For example, in 2007, the SASAC issued the Guidelines to the State-owned Enterprises Directly under the Central Government on Fulfilling Corporate Social Responsibilities. ${ }^{80}$ Among their provisions, the Guidelines require SOEs to publish CSR or sustainability reports on a regular basis, enhancing transparency of these companies and their performance on CSR issues.

Pursuant to those requirements, in 2011 the CNADC published its first social responsibility report, depicting how it has fulfilled CSR requirements on various issues such as worker's rights, environmental protection and food safety. ${ }^{81}$ Notably, the report also mentions the social responsibility of the company's agricultural overseas investment. It quotes some broad principles such as compliance with the local laws and regulations as a guide for the investment. In addition, it dedicates a section to "overseas community development" where it shows how the company creates "job opportunities", provides "skills training",

77 In 2012,69 SFEs were national LAEs. See the MOA, 《农业部办公厅关于做好农 艮农业产业化国家重点龙头企业监测工作的通知》，农办垦[2012]13号，February 2012, <http://www.moa.gov.cn/govpublic/NKJ/201202/t20120215_2481697.htm> (only available in Chinese)

78 See the official web site of the Guangdong Guangken Rubber Group Company Limited: <http://www.gdgkr.com>

${ }^{79}$ See the official web site of the China State Farms Agribusiness (Group) Corporation: <http://www.csfagc.cn/>

80 SASAC, 《关于中央企业履行社会责任的指导意见》， December 2007， <http://www.sasac.gov.cn/n2963340/n2964712/4891623.html> (only available in Chinese)

${ }^{81}<$ http://www.cnadc.com.cn/UpLoadFiles/File/中国农业发展集团2011年社会 责任报告.pdf> (only available in Chinese) 
contributes to "tax revenues" and helps develop the "agricultural economy" in three host countries of its investment in Africa, namely Benin, Zambia and Tanzania. ${ }^{82}$ Overall, however, the information in that section is rather limited and it remains to be seen and assessed whether the benefits of the investment are actually brought to the host countries. It thus appears that the CSR initiatives regulating SOEs are having an impact among SFEs and LAEs, including those investing overseas, but the actual effects of those policies in host countries need further scrutiny. ${ }^{83}$

In addition to these government initiatives to drive adoption of CSR practices, there are parallel efforts by other actors. For instance, in 2006 the Shenzhen Stock Exchange has issued the Guidelines to Listed Companies on Corporate Social Responsibility, promoting environmental protection and information disclosure. ${ }^{84}$ These can also help integrate CSR considerations into the operations of agricultural entities operating in China and overseas.

In summary, while the Chinese government and stock markets have developed a number of initiatives and policies relevant to responsible Chinese OFDI and the CSR of agricultural enterprises operating domestically, such initiatives and policies that are specifically targeted at agricultural OFDI are rather limited and underdeveloped, with very little relevant concrete guidance or regulations for those types of overseas investment.

It is important to highlight here that there seems very limited understanding of whether the CSR principles, provisions, guidelines and regulations mentioned above are truly followed and abided by and have any impact on the conduct of Chinese agricultural investors. To date, there seem very few in-depth studies about the social,

${ }^{82}$ See China National Agricultural Development Group Corporation (2012: 95-98).

${ }^{83}$ It is worth noting that overall, awareness and practice of CSR have increased in China. For example, more companies published CSR and sustainability reports. Nevertheless, there are still many criticisms about the actual implementation of CSR standards such as labour and environmental standards.

${ }^{84}$ Shenzhen Stock Exchange, 《上市公司社会责任指引》，2006. For the announcement of the launch of the Guidelines, see its official web site: <http://www. szse.cn/main/aboutus/bsyw/200609259303.shtml> (only available in Chinese) 
economic and environmental impacts of Chinese agricultural foreign investment. ${ }^{85}$ This is however not surprising, given the general lack of publicly available information about the investment, and accordingly enormous difficulty accessing and understanding Chinese investors and communities affected by their investment. Overall, the studies suggest that some of the investment does bring economic benefits such as job creation on plantations, increased agricultural productivity and growth of supporting businesses. However, in some cases, concerns are raised about the lack of contract enforcement, badly paid jobs and also environmental degradation.

\section{Conclusion}

The available data from the United Nations and the Chinese government show that China has become a major global source of OFDI in agriculture, especially, targeting ASEAN countries, with a prominent rising trend. The Chinese government, both at the central and the ministerial levels, has clear and proactive policies to endorse, support and drive agricultural overseas investment, particularly those of large Chinese companies like LAEs and SFEs. This means that Chinese agricultural OFDI, and Chinese policies regarding such OFDI, can have important and long-term impacts on the development of developing countries. However, there appears to be a comparatively limited amount of attention devoted to how to regulate Chinese agricultural OFDI. While the various government entities have issued some relevant policy statements and guidelines, such initiatives are few in number and remain broad and abstract with admittedly limited practical detail that is necessary to make them effective and valuable. Worse still, the understanding of the impacts of the initiatives on the conduct of Chinese agricultural investors is rather limited.

Yet some signs are positive: There is a growing amount of discourse, policies and guidelines regarding the CSR of Chinese OFDI

85 See Yan and Sautman (2010), Baumüller and Lazarus (2012), Woods (2013) and FAO (2013). It is worth mentioning that some studies look at interactions between Chinese and locals in agricultural cooperation projects while some document activities of Chinese overseas engagement in agricultural sector. These studies can be used for more in-depth impact studies. See Buckley. (2011), Zhang et al. (2012) and Bräutigam and Tang (2012a, 2012b). 
more generally, which demonstrates awareness and consensus among the Chinese leaders and also concerned ministries about the importance and the need of fulfilling CSR for Chinese companies investing overseas. Chinese leaders and government officials would thus likely be receptive to additional and more targeted efforts to promote CSR among Chinese agricultural overseas investors. These efforts can draw on the broad guiding principles of "mutual benefit" and "win-win" outcomes, specific initiatives developed by ministries such as the SFA, and China's particular expertise in how to use investment in agriculture to promote broad-based development, providing a useful basis for developing similar policies and guidelines on Chinese agricultural OFDI.

Notably, some relevant Chinese companies have started to adopt the practice of publishing CSR and sustainability reports, with some enterprises even reporting on the social responsibility of their agricultural overseas investment. ${ }^{86}$ It is an important early step. Nevertheless, these companies are few and a robust assessment of the impacts of the investment mentioned in the reports is much needed.

Overall, there are thus some encouraging developments but still significant challenges for the Chinese government and concerned ministries to promote CSR of Chinese agricultural OFDI. If the Chinese government is to turn the investment into a positive force in the development of host countries, especially those in the developing world targeted by the investment, the challenges are even bigger.

As a very first step to tackle those challenges, the Chinese government should develop a specific guide for Chinese agricultural OFDI, depicting what responsible Chinese companies should and should not do in practice when investing overseas. In the long term, it is of paramount importance for the Chinese government to proactively develop a robust and comprehensive policy and regulatory framework for Chinese agricultural investment, in line with international standards such as the Guiding Principles on Business and Human Rights, ${ }^{87}$ and the Voluntary Guidelines on the Responsible Governance of Tenure of

${ }^{86}$ See China Sustainability Reporting Resource Center: <http://www. sustainabilityreport.cn/> (only available in Chinese)

87 Report of the Special Representative of the Secretary-General on the issue of human rights and transnational corporations and other business enterprises, $\mathrm{A} /$ $\mathrm{HRC} / 17 / 31$, "Guiding Principles on Business and Human Rights: Implementing the United Nations 'Protect, Respect and Remedy' Framework". 
Land, Fisheries and Forests in the Context of National Food Security, 88 and the Voluntary Guidelines on the Right to Food. ${ }^{89}$ In addition, a monitoring and evaluation strategy should be put in place as an integral component of the framework, be resourced appropriately, and most important, involve stakeholders, especially local communities of host countries which are affected by Chinese investments.

In addition, especially in those developing countries where policies, laws and regulations governing agricultural investment and land tenure are inadequate due to loopholes, contradictions, or lack of clarity and transparency, and legal institutions and establishments are weak, the Chinese government should partner with other progressive investing countries to support the host countries in their efforts to develop, improve and strengthen their legal and policy frameworks and institutional capacities, rather than allowing this as an excuse for inaction.

After all, there is an urgent need to increase the understanding of the impacts of Chinese agricultural OFDI and investors on their host countries. More research is needed to be done, especially about the actual implementation and impacts of the guidelines and policies, either voluntary or mandatory, which various Chinese bodies have issued for promoting responsible Chinese agricultural OFDI. To conduct a good assessment of the impacts, researchers need to interrogate a range of questions such as: What are the costs, benefits, opportunities and risks for poor people, particularly smallholder farmers and rural women, arising from Chinese agriculture OFDI, especially in terms of human rights, the environment, gender equality and poverty? How are local customary land tenure systems, and land and resource use, and the general land reform agenda affected by the agriculture FDI? How do these changes affect community development, village governance, and thus the poor people? How are poor people - especially rural women - engaging in or being affected by the agriculture FDI? What are the consequences, both positive and negative, for men and women's livelihoods strategies and for their well-being, and especially the power relations between men and women? How does this vary between sectors and localities? Until we have a better understanding of these questions, it is impossible to assess whether, where and under what

\footnotetext{
88 FAO (2012b).
}

${ }^{89}$ FAO (2004). 
circumstances Chinese agricultural OFDI is an opportunity or threat for host countries' sustainable development, and what steps policy makers and business leaders must take in order to make sure that the promise of "win-win" investments is realised.

\section{References}

Baumüller, Heike and Kate Lazarus (2012). Agribusiness Investments in Lao PDR: Opportunities and Challenges for Poverty Reduction. Hong Kong: Oxfam Hong Kong.

Bräutigam, Deborah and Xiaoyang Tang (2012a). "An Overview of Chinese Agricultural and Rural Engagement in Ethiopia", IFPRI Discussion Paper, No. 01185. International Food Policy Research Institute.

Bräutigam, Deborah and Xiaoyang Tang (2012b). "An Overview of Chinese Agricultural and Rural Engagement in Tanzania", IFPRI Discussion Paper, No. 01214. International Food Policy Research Institute.

Bräutigam, Deborah and Haisen Zhang (2013). "Green Dreams: Myth and Reality in China's Agricultural Investment in Africa", Third World Quarterly, 34(9): 1676-1696.

Buckley, Lila (2011). "Eating Bitter to Taste Sweet: An Ethnographic Sketch of a Chinese Agriculture Project in Senegal". Paper presented at the International Conference on Global Land Grabbing, 6-8 April.

Buckley, Lila (2012). "Chinese Agriculture Goes Global: Food Security for all?", IIED Briefing Papers. International Institute for Environment and Development.

Campbell, Roderick, Tristan Knowles and Amphaphone Sayasenh (2012). "Business Models for Foreign Investment in Agriculture in the Lao People's Democratic Republic", TKN Report. International Institute for Sustainable Development.

China Export and Import Bank (2013). The Export-Import Bank of China Annual Report for 2012. Available at: <http://english.eximbank.gov.cn/annual/2012/2012nb01. shtml>

China National Agricultural Development Group Corporation (2012). Social Responsibility Report 2011.

FAO (2004). Voluntary Guidelines to Support the Progressive Realization of the Right to Food in the Context of National Food Security. Available at: http://www.fao.org/ docrep/meeting/009/y9825e/y9825e00.htm

FAO (2012a). The State of Food and Agriculture 2012: Investing in Agriculture for a Better Future. Rome: FAO. 
FAO (2012b). Voluntary Guidelines on the Responsible Governance of Tenure of Land, Fisheries and Forests in the Context of National Food Security. Available at: www. fao.org/nr/tenure/voluntary-guidelines/en/

FAO (2013). Trends and Impacts of Foreign Investment in Developing Country Agriculture: Evidence from Case Studies. Rome: FAO.

Macedo, Jorge Braga de, Luís Brites Pereira and José Mário Lopes (2009). "Drivers of China's Foreign Direct Investment into Africa", FEUNL Working Paper Series, No. 544.

Ministry Of Commerce, People's Republic of China (2004). 2003 Statistical Bulletin of China's Outward Foreign Direct Investment.

Ministry Of Commerce, People's Republic of China (2010). 2009 Statistical Bulletin of China's Outward Foreign Direct Investment.

Ministry Of Commerce, People's Republic of China (2011). 2010 Statistical Bulletin of China's Outward Foreign Direct Investment.

Ministry Of Commerce, People's Republic of China (2012). 2011 Statistical Bulletin of China's Outward Foreign Direct Investment.

Ministry Of Commerce, People's Republic of China (2013). 2012 Statistical Bulletin of China's Outward Foreign Direct Investment.

Ministry Of Commerce, People's Republic of China (2014). 2013 Statistical Bulletin of China's Outward Foreign Direct Investment.

OECD/FAO (2013). Agricultural Outlook 2013-2022. Paris: OECD.

Onphanhdala, Phanhpakit and Terukazu Suruga (2013). "Chinese Outward FDI in Agriculture and Rural Development: Evidence from Northern Laos", GSICS Working Paper Series, No. 25. Graduate School of International Cooperation Studies, Kobe University.

Rosen, Daniel H. and Thilo Hanemann (2009). "China's Changing Outbound Foreign Direct Investment Profile: Drivers and Policy Implications", Peterson Institute for International Economics Policy Brief, No. PB09-14.

Smaller, Carin, Wei Qiu and Yalan Liu (2012). Farmland and Water: China invests abroad. Winnipeg: International Institute for Sustainable Development.

Sun, Helen Lei (2011). "Understanding China's Agricultural Investments in Africa", Occasional Paper, No. 102. South African Institute of International Affairs.

U.S.-China Economic and Security Review Commission (2011). Going Out: An Overview of China's Outward Foreign Direct Investment.

UNCTAD (2009). World Investment Report 2009. New York and Geneva: United Nations.

UNCTAD (2014). World Investment Report 2014. New York and Geneva: United Nations.

Woods, K. (2013). Agribusiness Investments in Myanmar: Opportunities and Challenges for Poverty Reduction. Kunming, Yunnan: Yunnan University Press. 
World Bank (2008). World Development Report 2008. Washington, D.C.: World Bank.

World Wide Fund for Nature (2012). China Ecological Footprint Report 2012: Consumption, Production and Sustainable Development

Xing, Houyuan and Zhipeng Li (2011). “走出去” 营造新优势

Yan, Hairong and Barry Sautman (2010). "Chinese Farms in Zambia: From Socialist to 'Agro-Imperialist' Engagement?", African and Asian Studies, 9: 307-333.

Zha, Daojiong. (2013). Chinese FDI in Australia: Drivers and Perceptions.

Zhang, Li, Xiuli Xu and Xiaoyun Li (2012). 走出去的中国资本：文化遭遇与融合-针对 一家中资企业在坦桑尼亚的田野观

Zhang, Yan. (2010). “走出去” 的金融后盾. China Newsweek 


\section{Emerging-Market Multinationals, Human Rights, and Sustainable Development: Lessons from the Canadian Experience*}

\section{Sara L. Seck ${ }^{* *}$}

This paper will explore the dynamics of home State policies and practices relating to multinational enterprises in the extractive industries. The paper will first outline the Canadian experience, with a view to understanding the potential relationship between home State regulation and international frameworks. The content of the international corporate social responsibility (CSR) frameworks referenced in the Canadian context will also be examined. Second, the paper will explore the extent to which the international CSR frameworks that Canada has chosen to promote to extractive sector companies might also be appropriate frameworks for emerging market economies and their multinational enterprises to endorse. This part will ask whether and to what extent emerging market countries have participated in the creation of these frameworks, such that these frameworks could be viewed as legitimate standards for an emerging market country to apply to both domestic and international operations of their enterprises.

Key words: emerging market, extractive industry, corporate social responsibility

\section{Introduction: business, human rights and corporate social responsibility frameworks}

The role of home countries in influencing the sustainability performance of multinational enterprises (MNEs) in host countries has been actively debated in the mining context in some developed States. Canada, for example, has on more than one occasion considered whether to implement regulatory structures to ensure that home State mining companies do not

\footnotetext{
* The views expressed in this article are solely those of the authors and do not represent the views of the United Nations.

${ }^{* *}$ Associate Professor, Faculty of Law, Western University, Canada, sseck@uwo.ca The author would like to thank Western Law students Julius Tin-Luk Ko and Claire Lehan for their excellent research assistance.
} 
violate the human rights of host State local communities, including indigenous and other local communities concerned with environmental impacts. ${ }^{1}$ However, implementation of legal measures to address these issues, even when limited in application to conditionality of government support, has not been endorsed by the Canadian legislature due in part to fears of competitive disadvantage created by the activities of emerging market multinationals (EM MNEs). ${ }^{2}$ Instead, Canada has chosen to implement soft law non-judicial responses, such as the National Contact Point ${ }^{3}$ for the Organisation for Economic Co-operation and Development (OECD) Guidelines for Multinational Enterprises (MNE Guidelines), ${ }^{4}$ and a seemingly short-lived Corporate Social Responsibility (CSR) Counsellor for the Canadian Extractive Industries. ${ }^{5}$ The CSR Counsellor is mandated to refer to a defined set of international corporate social responsibility (CSR) frameworks comprised of the Performance Standards on Environmental and Social Sustainability of the International Finance Corporation, ${ }^{6}$ the Voluntary Principles on Security and Human Rights, ${ }^{7}$ and the Global Reporting Initiative. ${ }^{8}$

\footnotetext{
${ }^{1}$ Seck (2008a, 2011).

2 Seck (2011: 72-73).

${ }^{3}$ DFAIT, Canada's National Contact Point (NCP) for the Organisation for Economic Co-operation and Development (OECD) Guidelines for Multinational Enterprises (MNEs), available at: http://www.international.gc.ca/trade-agreements-accords-commerciaux/ ncp-pcn/index.aspx?lang=eng\&menu_id=1 (last visited October 8, 2014).

4 OECD (2011).

5 DFAIT, Welcome to the Office of the Extractive Sector Corporate Social Responsibility (CSR) Counsellor, available at: http://www.international.gc.ca/csr_ counsellor-conseiller_rse/index.aspx?view=d (last visited October 8, 2014)[CSR Counsellor]. The CSR Counsellor resigned in 2014 and has not yet been replaced. Another example is environmental and social risk assessment conducted by Export Development Canada, drawing upon the OECD's Recommendation on Export Credits and Environment. See generally EDC, Environment, available at: http://www.edc.ca/ en/about-us/corporate-social-responsibility/environment/pages/default.aspx (last visited October 8, 2014).

6 International Finance Corporation, Performance Standards on Environmental and Social Sustainability (2012), available at: http://www1.ifc.org/wps/wcm/co nnect/115482804a0255db96fbffd1a5d13d27/PS_English_2012_Full-Document. pdf?MOD=AJPERES (last visited October 8, 2014). The CSR Counsellor is mandated to refer to the earlier version of these standards.

7 Voluntary Principles on Security + Human Rights, "What are the Voluntary Principles?" available at: http://www.voluntaryprinciples.org/what-are-the-voluntaryprinciples/ (last visited October 13, 2014).

${ }^{8}$ Global Reporting Initiative (GRI), available at: https://www.globalreporting.org/ Pages/default.aspx (last visited October 10, 2014).
} 
The importance of the role of home States as regulators of transnational business with a duty to prevent and remedy human rights violations has also been considered at the United Nations Human Rights Council, most recently in the 2011 United Nations (UN) Guiding Principles on Business and Human Rights. ${ }^{9}$ According to Principle 1 of the Guiding Principles, states "must protect against human rights abuse within their territory and/or jurisdiction by third parties, including business enterprises". ${ }^{10}$ Principle 2 provides, more expansively but without compulsion, that "States should set out clearly the expectation that all business enterprises domiciled in their territory and/or jurisdiction respect human rights throughout their operations". ${ }^{11}$ With regard to access to remedy, Principle 25 provides that part of the State duty to protect is that "States must take appropriate steps to ensure, through judicial, administrative, legislative or other appropriate means, that when such abuses occur within their territory and/or jurisdiction those affected have access to effective remedy". ${ }^{12}$ Yet there is a lack of clarity in terms of how these principles apply to home countries, in part due to uncertainty over the application of "territory and/or jurisdiction" to transnational corporate actors legally understood as comprised of multiple separate legal personalities. ${ }^{13}$ Indeed, the Commentary to Principle 2 explicitly suggests that home States are not obligated under international law to regulate the "extraterritorial" activities of businesses, even though strong policy reasons exist to do so. ${ }^{14}$

The importance of the Guiding Principles for the purpose of this paper relates to both the State duty, described above, and the second pillar, which provides that businesses have a responsibility to respect human rights. ${ }^{15}$ As will be seen below, all of the international CSR frameworks promoted by Canada's office of the CSR Counsellor embed to differing degrees the business responsibility to respect human rights. Therefore, a useful contribution to implementation of both the

9 Report of the Special Representative of the Secretary-General on the Issues of Human Rights and Transnational Corporations and Other Business Enterprises, A/ HRC/17/31 "Guiding Principles on Business and Human Rights: Implementing the United Nations 'Protect, Respect and Remedy' Framework". [UN Guiding Principles]

10 UN Guiding Principles, op. cit. Principle 1.

11 UN Guiding Principles, op. cit. Principle 2.

12 UN Guiding Principles, op. cit. Principle 25.

${ }^{13}$ Seck (2010).

${ }^{14}$ UN Guiding Principles, op. cit. Commentary to Principle 2; Seck (2011).

${ }^{15}$ UN Guiding Principles, op. cit. Principles 11-24. 
State duty to protect and the business responsibility to respect rights could be for home countries with a prominent role in global resource extraction to promote a similar set of guidelines to their extractive sector companies for operations both at home and abroad.

This paper will explore the dynamics of home State policies and practices relating to MNEs in the extractive industries. The paper will first outline the Canadian experience, with a view to understanding the potential relationship between home State regulation and international frameworks. The content of the international CSR frameworks referenced in the Canadian context will also be examined here. Second, the paper will explore the extent to which the international CSR frameworks that Canada has chosen to promote to extractive sector companies might also be appropriate frameworks for EM States and EM MNEs to endorse. This part will ask whether and to what extent EM countries and EM MNEs have participated in the creation of these frameworks, such that these frameworks could be viewed as legitimate standards for an EM country to apply to both domestic and international operations of EM MNEs. ${ }^{16}$

\section{International CSR frameworks and the Canadian experience}

Canada plays a leading role in the financing of global mineral exploration and development. ${ }^{17}$ For example, in 2013, the Toronto Stock Exchange (TSX) and TSX Venture Exchange (TSX-V) were home to $56 \%$ of the world's public mining companies, ${ }^{18}$ and more global mining equity financings took place on the TSX/TSX-V than on any other exchange in the world. ${ }^{19}$ However, due to allegations of environmental and human rights violations arising from Canadian mining operations in developing countries, the Standing Committee on Foreign Affairs and International Trade issued a report (SCFAIT Report) in 2005 recommending that

16 On legitimacy and codes of conduct as regulators of transnational corporate conduct, see Keller (2008).

17 DFAIT, "Building the Canadian Advantage: A Corporate Social Responsibility Strategy for the Canadian Extractive Sector" (26 March 2009) p. 8, available at: http:// www.international.gc.ca/trade-agreements-accords-commerciaux/topics-domaines/ other-autre/csr-strat-rse.aspx?lang=eng (last visited October 8, 2014).

18 TMX, "Global Leader in Mining", (2013) at 1, available at: http://www.tmx.com/ en/pdf/Mining_Sector_Sheet.pdf (last visited October 8, 2014).

19 TMX, "Global Leader in Mining", op. cit. 
Canada consider adopting laws to alleviate these concerns..$^{20}$ The SCFAIT Report led to a series of multi-stakeholder roundtable discussions, ${ }^{21}$ a report from a multi-stakeholder advisory group, ${ }^{22}$ and an unsuccessful attempt to implement human rights and sustainability conditionality for Canadian Government support of mining companies operating in developing countries. ${ }^{23}$ Ultimately, a policy paper entitled "Building the Canadian Advantage: A Corporate Social Responsibility Strategy for the Canadian Extractive Sector" ${ }^{24}$ was put forward by the Canadian government, which, among other proposals, established the Office of the Extractive Sector CSR Counsellor. ${ }^{25}$

The CSR Counsellor is tasked with both reviewing the CSR practices of Canadian extractive companies operating outside of Canada and advising on the implementation of a set of performance guidelines. ${ }^{26}$ The limitations of the CSR Counsellor's dispute resolution structure have been the subject of much criticism, including notably the fact that companies must consent to participate in the process. ${ }^{27}$ Indeed, in October 2013 the CSR Counsellor resigned for undisclosed reasons and consultations have been held to determine the next best steps forward. ${ }^{28}$ In the interim, a private member's bill proposing the

20 House of Commons, Standing Committee on Foreign Affairs and International Trade (SCFAIT), Fourteenth Report: Mining in Developing Countries, 38th Parl, $1^{\text {st }}$ Sess (June 2005); Seck (2011: 55-59).

${ }^{21}$ Seck (2011: 59).

22 Advisory Group to the Roundtable, "National Roundtables on Corporate Social Responsibility (CSR) and the Canadian Extractive Industry in Developing Countries Advisory Group Report" (29 March 2007), available at: http://www.miningwatch. ca/sites/www.miningwatch.ca/files/RT_Advisory_Group_Report_0.pdf (last visited October 8, 2014); Seck (2011: 60-62).

23 Bill C-300, An Act Respecting Corporate Accountability for Mining, Oil and Gas Corporations in Developing Countries, 2nd Sess, 40th Parl (2009) [Bill C-300]; Seck (2011: 66-75).

24 DFAIT, "Building the Canadian Advantage: A Corporate Social Responsibility Strategy for the Canadian Extractive Sector", op. cit.; Seck (2011: 75-85).

${ }^{25}$ CSR Counsellor, op. cit.

${ }^{26}$ Order in Council, PC 2009-0422 (25 March 2009), available at: http://www.pcobcp.gc.ca/OIC-DDC.asp?lang=eng\&Page=\&txtOICID=2009-0422\&txtFromDate=\&txtT oDate $=$ \&txtPrecis $=$ \&txtDepartment $=$ \&txtAct $=$ \&txtChapterNo=\&txtChapterYear $=\& t x t$ BillNo=\&rdoComingIntoForce=\&DoSearch=Search+\%2F+List\&viewattach=20393 (last visited October 8, 2014)[Order in Council] s4.

27 Seck (2011: 82).

28 Trinh Theresa Do, “Ottawa's responsible mining review awaited by NGOs: Review of Canada's corporate social responsibility strategy likely won't recommend mining ombudsperson" CBC News (February 26, 2014), available at: http://www.cbc. $\mathrm{ca} / \mathrm{m} /$ touch/canada/story/1.2543080 (last visited October 10, 2014). 
appointment of a mining ombudsperson with greater powers than the CSR Counsellor was defeated in the House of Commons. ${ }^{29}$

For the purpose of this paper, however, what is of interest is the nature of the performance guidelines that the CSR Counsellor is required to apply during the review process. These are strictly designated ${ }^{30}$ as follows: (1) the International Finance Corporation (IFC) Performance Standards; (2) the Voluntary Principles on Security and Human Rights; (3) the Global Reporting Initiative; and (4) the Organisation of Economic Co-operation and Development (OECD) Guidelines for Multinational Enterprises (MNE Guidelines). ${ }^{31}$ Each of these will be briefly examined in turn below.

\subsection{IFC Performance Standards}

The International Finance Corporation (IFC) is one of five member institutions of the World Bank Group (WBG), although independent both financially and legally. ${ }^{32}$ Sharing the WBG mission to reduce global poverty, IFC is a large multilateral institution that assists in the mobilizing of financing for private sector enterprises investing in developing countries so that they may "create jobs, generate tax revenues, improve corporate governance and environmental

29 Bill C-584, "An Act respecting the Corporate Social Responsibility Inherent in the Activities of Canadian Extractive Corporations in Developing Countries" $2^{\text {nd }}$ Sess, 41 ${ }^{\text {st }}$ Parl (2014), available at: http://openparliament.ca/bills/41-2/C-584/ (last visited October 10, 2014).

30 Order in Council, op. cit., s1, ss5(5); IFC Performance Standards, op. cit., Voluntary Principles, op. cit., GRI, op. cit.

${ }^{31}$ Order in Council, op. cit., s1. The OECD National Contact Point (NCP) is, however, to remain the "primary authority" with regard to the OECD MNE Guidelines. Order in Council, op. cit. ss5(2)-(4). While this paper will focus on the OECD MNE Guidelines, it is important to note that the OECD has been influential in establishing environmental and social standards applicable to Export Credit Agencies, as well as anti-bribery standards, among others. See OECD, Common Approaches on Export Credits and the Environment and Social Due Diligence (2012), available at: http://www. oecd.org/tad/exportcredits/environmentalandsocialduediligence.htm (last visited October 8, 2014); OECD, Anti-Bribery Measures and Export Credits, available at: http:// www.oecd.org/tad/exportcredits/anti-briberymeasures.htm (last visited October 8, 2014); as well as OECD Convention on Combating Bribery of Foreign Public Officials in International Business Transactions (1997), available at: http://www.oecd.org/daf/ briberyininternationalbusiness/oecdantibriberyconvention.htm (last visited October 8 , 2014).

32 Morgera (2009: 146). 
performance, and contribute to their local communities". ${ }^{33}$ In pursuit of this goal, the IFC promotes a Sustainability Framework, which articulates the IFC's commitment to sustainable development as part of risk management strategy. ${ }^{34}$ This framework is comprised of the IFC's Policy and Performance Standards on Environmental and Social Sustainability, the Access to Information Policy and the Policy on Social and Environmental Sustainability. ${ }^{35}$ The IFC's Policy on Social and Environmental Sustainability outlines the IFC's responsibility in supporting project performance in partnership with clients. ${ }^{36}$ The Performance Standards, which also touch on environmental and social responsibilities, have a different focus, as they centre on the client's responsibilities for managing their environmental and social risks. ${ }^{37}$ Compliance with the Performance Standards is a condition of IFC financing support. ${ }^{38} \mathrm{An}$ independent Compliance Advisor Ombudsman is charged with responding to complaints by project-affected communities concerned with environmental and social impacts. ${ }^{39}$

The original Performance Standards were released in 1998, updated in 2006, and updated again in 2011 after an 18-month review. ${ }^{40}$ The 2012 Performance Standards provide guidance on: (1) the Assessment and Management of Environmental and Social Risks; (2) Labor and Working Conditions; (3) Resource Efficiency and Pollution

${ }^{33}$ Morgera (2009: 146); IFC, About IFC, available at: http://www.ifc.org/wps/wcm/ connect/corp_ext_content/ifc_external_corporate_site/about+ifc (last visited October 10, 2014).

${ }^{34}$ IFC, IFC's Sustainability Framework, available at: http://www.ifc.org/ sustainabilityframework (last visited October 8, 2014).

35 IFC, "Performance Standards on Environmental and Social Sustainability" (January 1, 2012), available at: http://www1.ifc.org/wps/wcm/connect/115482804a 0255db96fbffd1a5d13d27/PS_English_2012_Full-Document.pdf?MOD=AJPERES (last visited October 8, 2014).

36 IFC, "International Finance Corporation's Policy on Environmental and Social Sustainability", (January 1, 2012), available at: http://www.ifc.org/wps/wcm/connec t/7540778049a792dcb87efaa8c6a8312a/SP_English_2012.pdf?MOD=AJPERES (last visited October 10, 2014) p. 1.

37 IFC, "International Finance Corporation's Policy on Environmental and Social Sustainability", op. cit.

${ }^{38}$ Morgera (2009: 209-216).

39 Morgera (2009: 216-222); Compliance Advisor Ombudsman, Our Mandate, available at: http://www.cao-ombudsman.org/ (last visited October 8, 2014).

40 Morgera (2009: 147-148); IFC Sustainability: Our Approach, Risk Management, Sustainability Framework, available at: http://www.ifc.org/wps/wcm/connect/ topics_ext_content/ifc_external_corporate_site/ifc+sustainability/our+approach/ risk+management/sustainability+framework (last visited October 8, 2014). 
Prevention; (4) Community Health, Safety and Security; (5) Land Acquisition and Involuntary Resettlement; (6) Biodiversity Management and Sustainable Management of Living Natural Resources; (7) Indigenous Peoples; and (8) Cultural Heritage. ${ }^{41}$ Performance Standard 1 explicitly recognizes the business responsibility to respect human rights, and notes that each performance standard has a human rights dimensions that can be identified if clients are guided by them when engaging in due diligence. ${ }^{42}$

\subsection{Voluntary Principles on Security and Human Rights}

The Voluntary Principles on Security and Human Rights were collectively designed with the aim to guide extractive sector companies "in maintaining the safety and security of their operations within an operating framework that ensures respect for human rights and fundamental freedoms". ${ }^{43}$ Established in 2000 by the Governments of the United Kingdom and the United States, the Voluntary Principles guide companies operating within the extractive industry in conducting comprehensive human rights risk assessments to ensure that human rights are respected in the protection of company facilities and premises when public or private security providers are engaged. ${ }^{44}$ The three pillars of the Principles are: (1) risk assessment; (2) interactions between companies and public security; and (3) interactions between companies and private security ${ }^{45}$ Any extractive company wishing to join the Voluntary Principles Initiative and the Voluntary Principles Association must submit a form request of admission together with an

${ }^{41}$ IFC, "Performance Standards on Environmental and Social Sustainability", op. cit.; Michael Torrance, ed., IFC Performance Standards on Environmental \& Social Sustainability: A Guidebook (Markham, Ontario: LexisNexis Canada, 2012).

42 IFC, "Performance Standards on Environmental and Social Sustainability", op. cit. p.6.

${ }^{43}$ The Voluntary Principles on Security + Human Rights, The Principles Introduction, available at: http://www.voluntaryprinciples.org/principles/introduction (last visited October 8, 2014).

44 Voluntary Principles on Security and Human Rights, Fact Sheet, available at: http://www.state.gov/j/drl/rls/fs/2012/202314.htm (last visited October 8, 2014).

45 Voluntary Principles on Security and Human Rights, Fact Sheet, op. cit. 
Action Plan detailing how the company currently implements and plans to implement the Voluntary Principles. ${ }^{46}$

As the Voluntary Principles are designed to encourage dialogue, any Participant's status will automatically become inactive if it fails to submit an annual report that meets agreed criteria, or refuses to engage in direct dialogue with another participant, including non-governmental organizations (NGO) or government participants. If concerns are raised about a particular Participant, members will seek to resolve any issues through direct dialogue. If this fails, the Participant may be expelled through consensus. ${ }^{47}$

\subsection{Global Reporting Initiative}

The Global Reporting Initiative (GRI) ${ }^{48}$ is an international multistakeholder, network-based organization that provides companies and organizations including non-profits with a sustainability-reporting framework that promotes economic, environmental, and social sustainability. ${ }^{49}$ The initiative was founded in 1997 by the Center for Environmentally Responsible Economies (CERES) and the Tellus Institute. Shortly thereafter a multi-stakeholder steering committee was organized, and through this the reporting framework was developed and launched in $2000 .^{50}$ The goal of the initiative is to create a uniform sustainability reporting framework to make it easier to access standardized, comparable and consistent information about an organization's performance. Reporting focuses on environmental, social, economic, and governance issues. ${ }^{51} \mathrm{~A}$ second generation of the Guidelines known as the G2 was released in 2002, while the G3 Guidelines were launched in 2006. These were updated in March 2011 and published as the G3.1 Guidelines. ${ }^{52}$ The most recent update to the

46 Voluntary Principles on Security + Human Rights, "Voluntary Principles on Security and Human Rights Participation Criteria", available at: http://www. voluntaryprinciples.org/files/VPs_Participation_Criteria_Final_-_127000_v1_FHE-DC. PDF (last visited October 8, 2014).

47 Voluntary Principles on Security and Human Rights Participation Criteria, op. cit.

${ }^{48}$ Global Reporting Initiative (GRI), op. cit.

${ }^{49} \mathrm{GRI}$, What is GRI, available at: https://www.globalreporting.org/information/ about-gri/what-is-GRI/Pages/default.aspx (last visited October 10, 2014).

${ }^{50} \mathrm{GRI}$, What is GRI, op. cit.

${ }^{51} \mathrm{GRI}$, What is GRI, op. cit.; Brown (2011: 281).

${ }^{52} \mathrm{GRI}$, What is GRI, op. cit. 
GRI Sustainability Reporting Guidelines was released in May 2013 as the fourth generation $\mathrm{G} 4 .{ }^{53}$

The GRI Reporting Guidelines provide the core content for GRI reporting in two parts, first through "Reporting Principles and Standard Disclosures," and second in an "Implementation Manual". ${ }^{4}$ General standard disclosures include with regard to organizational profile, stakeholder engagement, governance, and ethics and integrity, while specific disclosures on management approach indicators address environmental and social issues, including labour practices, human rights, and society. ${ }^{55}$ The GRI also provides guidance by way of sector specific reporting standards (sector supplements), offering specific direction on how companies can best comply with the GRI in their field. The mining and metals sector is an example of one area in which the GRI has provided supplemental guidance. Key sector-specific issues covered in the Mining and Metals Supplement include biodiversity management and ecosystem services, community consultation, indigenous people's rights in exploration, number and handling of land disputes, local community resettlement, relationship with artisanal and small-scale mining, and mine closure plans. ${ }^{56}$

\subsection{OECD MNE Guidelines}

The OECD initially put forward the OECD MNE Guidelines in 1976 as an Annex to the Declaration on International Investment and Multinational Enterprises. ${ }^{57}$ The OECD MNE Guidelines describe themselves as "recommendations addressed by governments to multinational enterprises operating in or from adhering countries" providing non-binding principles and standards for businesses in a global context. ${ }^{58}$ The guidelines have been revised three times since

53 GRI, G4 Sustainability Reporting Guidelines, available at: https://www. globalreporting.org/reporting/g4/Pages/default.aspx (last visited October 10, 2014).

54 GRI, G4 Sustainability Reporting Guidelines, op. cit.

55 GRI, G4 Sustainability Reporting Guidelines, op. cit.

56 GRI, G4 Sector Disclosures, Mining and Metals, available at: https://www. globalreporting.org/resourcelibrary/GRI-G4-Mining-and-Metals-Sector-Disclosures. pdf (last visited October 10, 2014).

57 Declaration on International Investment and Multinational Enterprises, OECD Declaration C(76)99/FINAL (1976), available at: http://webnet.oecd. org/OECDACTS/Instruments/ShowlnstrumentView.aspx? InstrumentID=241\& InstrumentPID=270\&Lang=en\&Book= (last visited October 8, 2014).

58 OECD MNE Guidelines, op. cit., at 3. 
initial adoption in 1976, with the addition of new environmental provisions in 1991, and with more wide-ranging changes being made in $2000 .^{59}$ The most recent update in 2011 , focused on promoting responsible business conduct, including an updated human rights chapter and guidance on corporate due diligence and responsible supply chain management. ${ }^{60}$ In addition to a discussion of General Policies, ${ }^{61}$ the OECD MNE Guidelines specifically address many topics of relevance to global mining: (1) disclosure, ${ }^{62}$ (2) human rights, ${ }^{63}$ (3) employment and industrial relations, ${ }^{64}(4)$ environment, ${ }^{65}(5)$ bribery, ${ }^{66}$ (6) consumer interests, ${ }^{67}$ (7) science and technology, ${ }^{68}$ (8) competition ${ }^{69}$ and (9) taxation. ${ }^{70}$

Though the standards are non-binding for MNEs, the OECD does require adhering countries to implement a mechanism designed to encourage compliance, in the form of National Contact Point Agencies, initially proposed in 2000. ${ }^{71}$ The National Contact Point mechanisms also offer mediation services in relation to complaints submitted as "specific instances" that allege corporate contravention of the MNE Guidelines, and must contribute to the resolution of the practical issues raised in the implementation of the Guidelines. ${ }^{72}$ Many National

59 Halina Ward, "The OECD Guidelines for Multinational Enterprises and nonadhering countries Opportunities and Challenges of engagement", available at: http:// www.oecd.org/daf/inv/investmentfordevelopment/33807204.pdf (last visited October 8, 2014).

60 OECD, "2011 Update of the OECD Guidelines for Multinational Enterprises Comparative table of changes made to the 2000 text", available at: http://www.oecd. org/daf/inv/mne/49744860.pdf (last visited October 8, 2014).

61 OECD MNE Guidelines, op. cit., at 19.

62 OECD MNE Guidelines, op. cit., at 27.

${ }^{63}$ OECD MNE Guidelines, op. cit., at 31.

${ }^{64}$ OECD MNE Guidelines, op. cit., at 35.

65 OECD MNE Guidelines, op. cit., at 42.

${ }^{66}$ OECD MNE Guidelines, op. cit., at 47.

${ }^{67}$ OECD MNE Guidelines, op. cit., at 51.

${ }^{68}$ OECD MNE Guidelines, op. cit., at 55.

${ }^{69}$ OECD MNE Guidelines, op. cit., at 57.

70 OECD MNE Guidelines, op. cit., at 60.

${ }^{71}$ OECD, Decision of the Council on the OECD Guidelines for Multinational Enterprises, OECD Decision C(2000)96/FINAL (2000), as amended by OECD Decision C/MIN(2011)11/FINAL (2011) at I(1)-(4), available at: http://webnet.oecd.org/ OECDACTS/Instruments/ShowInstrumentView.aspx?InstrumentID=233\&InstrumentP $I D=271$ \&Lang=en\&Book (last visited October 8, 2014).

72 OECD, National Contact Points for the OECD Guidelines for Multinational Enterprises, available at: http://www.oecd.org/daf/inv/mne/ncps.htm (last visited October 8, 2014). 
Contact Point procedures have been heavily criticized as ineffective and under-resourced, although a few have received favourable ratings from civil society experts. ${ }^{73}$

\section{CSR frameworks and emerging market multinational home States}

As discussed in the introduction to this paper, the international CSR frameworks described above were endorsed by the Government of Canada in a 2009 CSR strategy policy paper for the mining industry, and integrated into the structure of the Canadian CSR Counsellor's mandate. ${ }^{74}$ It is commonly stated in Canada that these frameworks are international standards. This part will explore the extent to which these international CSR frameworks can be said to be international standards from the perspective of EM MNEs and EM home countries, such that if an EM home country considered implementation of a similar transnational regulatory oversight mechanism, they too might refer to the same international standards. Specifically, this part will seek to determine to what extent EM MNE and EM MNE home States have either participated in the development of the institutions out of which these standards have emerged, or participated in the drafting of the standards themselves, or to what extent they have subsequently endorsed or signed on as participants in these initiatives, where this is possible.

As a preliminary matter, for the purpose of this paper, the specific definition of emerging market country is not important. ${ }^{75}$ What is important is that the countries of particular interest are not considered developed States, and are home to MNEs that are active in the global mining sector, as well as the oil \& gas sector. Prominent examples would include, for example, Brazil, China and South Africa. An

${ }^{73}$ OECD Watch, "Assessment of NCP Performance in the 2013-2014 Implementation Cycle: OECD Watch Submission to the 2014 Annual Meeting of the National Contact Points" (Amsterdam, 2014), available at: http://oecdwatch.org/publications-en/ Publication_4090 (last visited October 10, 2014).

74 DFAIT, "Building the Canadian Advantage: A Corporate Social Responsibility Strategy for the Canadian Extractive Sector", op. cit.; Seck (2011: 75-85).

75 For a discussion of various approaches to the definition of emerging markets, see: Wikipedia, "Emerging Markets," available at: http://en.wikipedia.org/wiki/ Emerging_markets (last visited October 14, 2014). 
EM MNE then is defined as one with corporate headquarters in an EM country or a listing on an EM stock exchange.

Much literature, including by the author, focuses on developed country home States of MNEs, and argues that home States have an obligation to regulate and adjudicate MNE conduct to prevent and remedy violations of international human rights law. ${ }^{76}$ However, with recent shifts in the power of EM States and EM MNEs perhaps especially in the resource extraction context, it is important to draw attention to a possible role for EM MNE home States. ${ }^{77}$ All of the CSR frameworks promoted by Canada's office of the CSR Counsellor embed to differing degrees the business responsibility to respect human rights. Therefore, a useful contribution to implementation of both the State duty to protect and the business responsibility to respect human rights might be for home countries with a prominent global role in resource extraction to promote a similar set of guidelines to their extractive sector companies for operations both at home and abroad. While developed country home States often appear to have played a similar role in relation to each of these frameworks, this is not clearly the case for EM countries nor for EM MNEs, and so merits examination. The rationale behind the method of exploration undertaken here is that greater participation in the frameworks by EM countries and EM MNEs lends greater legitimacy to the use of these frameworks by EM countries to measure EM MNE conduct. $^{78}$

\subsection{IFC Performance Standards}

The IFC is collectively owned by 184 member countries who together determine IFC policies in the more than 100 developing countries in which IFC works. ${ }^{79} \mathrm{~A}$ Board of Governors and a Board of Executive Directors guide the programs and activities of the IFC. ${ }^{80}$ Each member country may appoint one governor and one alternate to sit

${ }^{76}$ Seck (2008a, 2010, 2012), Simons and Macklin (2014).

77 Chimni (2012).

78 See Keller (2008), especially pp. 259-260 on deliberative democracy and legitimacy.

79 IFC, About IFC, available at: http://www1.ifc.org/wps/wcm/connect/corp_ext_ content/ifc_external_corporate_site/about+ifc (last visited October 8, 2014).

${ }^{80}$ IFC, About IFC: Governance, available at: http://www.ifc.org/wps/wcm/ connect/CORP_EXT_Content/IFC_External_Corporate_Site/About+IFC/Organization/ IFC_Governance (last visited October 8, 2014). 
on the Board of Governors. ${ }^{81}$ Most of the powers and responsibilities at the IFC however are delegated to the Board of Directors, with voting power weighted "according to the share capital each director represents". ${ }^{82}$ The IFC Board of Directors has 25 members of whom 6 are appointed and 19 elected. The appointed directors as of 2014 are from China, France, United Kingdom, Japan, Germany, and the United States. ${ }^{83}$ The 19 other directors are elected from the membership and currently include directors from Argentina, India, Mexico, Nigeria, the Philippines and the Russian Federation, among others. ${ }^{84}$

As noted, voting at the Board of Governors and Board of Directors is directly tied to the amount of money that the member State has invested in the IFC..$^{85}$ The United States has by far the greatest voting power at $21.52 \%$, while EM countries India and the Russian Federation each have $3.91 \%$, China 2.35\%, Brazil 1.52\%, and South Africa 0.69\%, for example. ${ }^{86}$ The voting share at the level of Board of Directors is also broken down based on funding. However in this case, the percentage is a total of the voting share of all of the member States that voted for each elected director. ${ }^{87}$ Thus it can be said that EM countries do play a role in IFC governance, but this role is overpowered by US dominance.

81 IFC, About IFC: Governance, op. cit.

82 IFC, About IFC: Governance, op. cit.

83 For a list of a list of the current Directors and the countries they represent, see: The World Bank, "International Bank for Reconstruction and Development International Finance Corporation - International Development Association", available at: http://siteresources.worldbank.org/BODINT/Resources/278027-1215526322295/ BankExecutiveDirectors.pdf (last visited October 8, 2014); The World Bank, Election or Appointment of Executive Directors, available at: http://web.worldbank.org/WBSITE/ EXTERNAL/EXTABOUTUS/ORGANIZATION/BODEXT/0,,contentMDK:20124813 menuP K:3700231 pagePK:64020054 piPK:64020408 theSitePK:278036,00.html (last visited October 8, 2014).

84 The World Bank, "International Bank for Reconstruction and Development International Finance Corporation - International Development Association, op. cit.

${ }^{85}$ World Bank, "International Finance Corporation Subscriptions and Voting Power of Member Countries", available at: http://siteresources.worldbank.org/BODINT/ Resources/278027-1215524804501/IFCCountryVotingTable.pdf (last visited October 8, 2014).

${ }^{86}$ World Bank, "International Finance Corporation Subscriptions and Voting Power of Member Countries", op. cit.

87 World Bank, "International Finance Corporation Voting Power of Directors", available at: http://siteresources.worldbank.org/BODINT/ Resources/278027-1215524804501/IFCEDsVotingTable.pdf (last visited October 8, 2014). 
It is also necessary to consider the process that led to the drafting and updating of the performance standards themselves. For example, in 2009, the IFC began the process of reviewing the Policy and Performance Standards on Social and Environmental Sustainability. This review was conducted through a series of consultations with various stakeholders, which were divided into three phases. The first 60 day consultation period focused on soliciting stakeholder comments in three main areas: increasing clarity of language, improving implementation effectiveness, and closing the gaps in current coverage. ${ }^{88}$ During this phase the IFC conducted consultations with a wide range of stakeholders including multilateral banks, bilateral banks, commercial financial institutions including the Steering Committee of Equator Principles Financial Institutions, trade unions, select UN agencies, Indigenous Peoples, conservation organizations, business associations, individual companies, the NGO and CSO community, World Bank Group colleagues, and the External Advisory Group. ${ }^{89}$ The second phase and third phases were 90 and 60-day consultation periods respectively on changes to the draft text. During this time, the IFC held multistakeholder and open houses around the world, including, for example, in Brazil, Columbia, Ghana, India, the Philippines, Peru, the Russian Federation, Senegal, and South Africa. ${ }^{90}$ The updated sustainability framework came into effect on 1 January 2012.

The IFC Performance Standards were designed to apply to projects in developing countries as part of the World Bank Group's focus on poverty alleviation and sustainable development. ${ }^{91}$ Indeed, a key reason for the Canadian Government's choice of the IFC Performance

88 IFC, "IFC Policy and Performance Standards on Social and Environmental Sustainability and Policy on Disclosure of Information, Review and Update 'Progress Report on Phase I of Consultation'” (January 11, 2010), p. 2, available at: http://www1. ifc.org/wps/wcm/connect/218db10049800b2eada9ff336b93d75f/Phasel_Progress_ Report1-11-10.pdf?MOD=AJPERES (last visited October 8, 2014).

89 IFC, "IFC Policy and Performance Standards on Social and Environmental Sustainability and Policy on Disclosure of Information, Review and Update 'Progress Report on Phase I of Consultation'”, op. cit.

90 IFC, Chronology of IFC's Sustainability Framework Review and Update Process (April 14, 2011), Annex F, in IFC, Update of IFC's Policy and Performance Standards on Environmental and Social Sustainability, and Access to Information Policy (April 14, 2011, pp. 104-105, available at: http://www.ifc.org/wps/ wcm/connect/fca42a0049800aaaaba2fb336b93d75f/Board-Paper-IFC_ SustainabilityFramework-2012.pdf?MOD=AJPERES (last visited October 13, 2014).

91 Morgera (2009: 146;), IFC, About IFC, op. cit. 
Standards as an international standard was the view that they are "de facto performance benchmarks for projects in developing countries that require substantial financial investment". ${ }^{92}$ The IFC Performance Standards have been widely endorsed, and are regularly incorporated into investment agreements and financing contracts. ${ }^{93}$ Moreover, the IFC Performance Standards are used as a benchmark by other financial institutions, such as, for example, signatories to the voluntary Equator Principles. ${ }^{94}$ Eighty per cent of global financing for extractive sector projects is provided by these institutions, which agree to adopt lending practices consistent with the IFC Performance Standards. ${ }^{95}$ However, over thirty wealthy countries - none are EMs - are designated by the Equator Principles as having sufficiently "robust environmental and social governance, legislation systems and institutional capacity designed to protect their people and the natural environment". ${ }^{96}$ In these countries, which are essentially high-income OECD countries, their own review processes are considered a sufficient substitute. ${ }^{97}$ While the majority of the 80 Equator Principles Financial Institutions are from developed States, there are members from a number of EM countries including Brazil, China, India, Mexico and Nigeria, among others. ${ }^{98}$

It is important to note that a recent development has been the announcement of the creation of a BRICS (Brazil, the Russian Federation, India, China and South Africa) bank that would rival the World Bank Group including the role of the IFC. It remains to be seen

92 DFAIT, "Building the Canadian Advantage: A Corporate Social Responsibility Strategy for the Canadian Extractive Sector" op. cit. p.8. See Seck (2011).

93 Michael Torrance, "IFC performance standards: A benchmark for CSR", Canadian Mining Journal (Sept 2012), available at: http://www.canadianminingjournal. com/news/ifc-performance-standards-a-benchmark-for-csr/1001703090/ (last visited October 13, 2014).

${ }^{94}$ Equator Principles, the Equator Principles III, available at: http://www.equatorprinciples.com/index.php/equator-principles-3 (last visited October 14, 2014).

95 Canada, DFAIT, "Building the Canadian Advantage: A Corporate Social Responsibility Strategy for the Canadian Extractive Sector", op. cit. p.8.

96 Equator Principles, Designated Countries, available at: http://www.equatorprinciples.com/index.php/ep3/designated-countries (last visited October 13, 2014).

97 Equator Principles, the Equator Principles III, op. cit.

98 Equator Principles "Members and Reporting", available at: http://www.equatorprinciples.com/index.php/members-reporting (last visited October 13, 2014). 
what this might entail and whether similar performance standards to those of the IFC would be adopted in relation to project financing. ${ }^{99}$

\subsection{Voluntary Principles on Security and Human Rights}

The Voluntary Principles on Security and Human Rights were announced in December 2000 by the Governments of the United Kingdom and the United States. The Principles were the outcome of multi-stakeholder discussions that brought together the United Kingdom Foreign Office and United States Department of State, several oil \& gas and mining companies, and a number of NGOs, "all with an interest in human rights and corporate responsibility". ${ }^{100}$ In November 2012, the non-profit organization the Voluntary Principles Association was formed to address administrative needs so as to enhance the capacity of the initiative to facilitate collaborative work among governments, companies and non-governmental organizations. ${ }^{101}$

As of October 2014, there are 9 participating governments, including the founders and Australia, Canada, the Netherlands, Norway, Switzerland, as well as Columbia and Ghana. ${ }^{102}$ Eleven nongovernmental organizations currently participate, with several of these based in Africa including LITE Africa, the New Nigeria Foundation, and Partnership Africa Canada. ${ }^{103}$ There are currently 26 participating companies, all with global operations including Rio Tinto, Barrick Gold,

${ }^{99}$ Oxfam Policy Brief, "The BRICS Development Bank: Why the world's newest global bank must adopt a pro-poor agenda" (July 11, 2014), available at: http://www. oxfam.org/sites/www.oxfam.org/files/bp-brics-development-bank-110714-en.pdf (lat visited October 14, 2014).

100 Voluntary Principles on Security + Human Rights, What are the Voluntary Principles? op. cit.; Voluntary Principles on Security + Human Rights, available at: http://www.voluntaryprinciples.org/files/voluntary_principles_english.pdf (last visited October 13, 2014).

${ }^{101}$ Voluntary Principles on Security + Human Rights, Voluntary Principles Announces the Formation of the Voluntary Principles Association, (November 21, 2012), available at: http://www.voluntaryprinciples.org/wp-content/uploads/2013/03/Voluntary_ Principles_Association_Press_Release_-_November_21_2012.pdf (last visited October 13, 2014).

102 Voluntary Principles on Security + Human Rights, For Governments, available at: http://www.voluntaryprinciples.org/for-governments/ (last visited October 13, 2014).

${ }^{103}$ Voluntary Principles on Security + Human Rights, For NGOs, available at: http:// www.voluntaryprinciples.org/for-ngos/ (last visited October 13, 2014). 
Chevron, and Total. ${ }^{104}$ The only participating company which has a headquarters based in an EM country is the South African gold miner AngloGold Ashanti. ${ }^{105}$ There is no evidence of government, company or NGO participants from Brazil, China or India.

The Voluntary Principles have had little engagement from EM MNEs and EM home countries, but this could change as a result of the development of an Implementation Guidance Tool (IGT) for the Voluntary Principles announced in 2011. ${ }^{106}$ The IGT was "co-financed and developed" by the International Council on Mining and Metals (ICMM), together with the International Finance Corporation (IFC), the global oil and gas industry association for environmental and social issues known as IPIECA, and the International Committee of the Red Cross (ICRC). ${ }^{107}$ Many company members of the Voluntary Principles are also members of either ICMM or IPIECA, and both have members that are EM MNEs. For example, among members of the ICMM are several EM MNEs including Codelco (Chile), and South Africa companies Goldfields, African Rainbow Minerals, and AngloGold Ashanti, ${ }^{108}$ while members of IPIECA include among others Petrobas (Brazil), CNOOC (China), Libya NOC (Libya), RasGas (Qatar), and Petronas (Malaysia). ${ }^{109}$ Furthermore both ICMM and IPIECA have a global range of industry association members. ${ }^{110}$ Thus, while the Voluntary Principles themselves appear to have limited direct engagement with EM MNEs and EM home States, the representativeness of the participants in ICMM and IPIECA and by extension the IGT suggests a potentially broader reach.

${ }^{104}$ Voluntary Principles on Security + Human Rights, For Companies, available at: http://www.voluntaryprinciples.org/for-companies/ (last visited October 13, 2014).

105 Voluntary Principles on Security + Human Rights, For Companies, op. cit.; AngloGold Ashanti, A Truly Global Producer of Gold, available at: http://www. anglogoldashanti.com/en/Pages/default.aspx (last visited October 13, 2014).

${ }^{106}$ ICMM, "Voluntary Principles on Security and Human Rights: Implementation Guidance Tool" (2011), available at: http://www.icmm.com/document/2199 (last visited October 10, 2014).

107 ICMM, Voluntary Principles on Security and Human Rights: Implementation Guidance Tools, op. cit.

108 ICMM, Member companies, available at: http://www.icmm.com/members/ member-companies (last visited October 10, 2014).

109 IPIECA, Membership, available at: http://www.ipieca.org/membership (last visited October 10, 2014).

110 ICMM, Member Associations, available at: http://www.icmm.com/members/ member-associations (last visited October 13, 2014); IPIECA, Membership, op. cit. 
The Voluntary Principles on Security and Human Rights are structured so as to allow the participation or engagement of governments whether they are host or home or both to extractive sector company participants. ${ }^{111}$ In terms of scope of application, while it might be assumed that the premise behind the Voluntary Principles on Security and Human Rights is that companies operating in conflictaffected areas require extra guidance when dealing with security forces, whether public or private, the structure of the Voluntary Principles does not preclude its application to any country context. Indeed, the Voluntary Principles appear designed to support human rights due diligence wherever operations take place. ${ }^{112}$

\subsection{Global Reporting Initiative}

The GRI is a global network governed by three separate bodies, a Board of Directors, a Stakeholder Council, and a Technical Advisory Committee. These governance bodies direct GRI activities and oversee the GRI's reporting guidance. The Technical Advisory Committee is responsible for the content of the GRI Framework ${ }^{113}$ while the Stakeholder Council provides guidance on strategic and policy issues and debates the proposed changes to the Framework content. ${ }^{114}$ The Board of Directors then makes the final decision regarding the release of the Framework material. ${ }^{115}$

The GRI Board of Directors has a maximum of 16 members, and currently includes representation from Brazil, China, India, the Philippines, and South Africa. ${ }^{116}$ The Technical Advisory Committee has a maximum of 15 members, with current representation including

111 The Voluntary Principles Initiative and the Voluntary Principles Association "Framework for Admission of New Governments", available at: http://www. voluntaryprinciples.org/files/VPs_Government_Entry_Framework.pdf (last visited October 10, 2014).

112 The Voluntary Principles on Security + Human Rights, "The Principles Introduction", available at: http://www.voluntaryprinciples.org/principles/introduction (last visited October 10, 2014).

113 GRI, Governance Bodies, available at: https://www.globalreporting.org/ network/network-structure/governance-bodies/Pages/default.aspx (last visited October 13, 2014).

114 GRI, Governance Bodies, op. cit.

$115 \mathrm{GRI}$, Governance Bodies, op. cit.

$116 \mathrm{GRI}$, Board of Directors, available at: https://www.globalreporting.org/ network/network-structure/board-of-directors/Pages/default.aspx (last visited October 13, 2014). 
from Argentina, Brazil, India, and South Africa. ${ }^{117}$ The Stakeholder Council, a multi-stakeholder forum of up to 50 members, has a diverse membership "drawn from all United Nations-defined regions: Africa, Asia Pacific/Oceania, Latin America/Caribbean, North America/ Europe/CIS and West Asia", representing "core constituencies in GRI's network: Business, Civil Society Organizations, Labor and Mediating Institutions". ${ }^{118}$

In 2008, a Governmental Advisory Group was established as an informal "high-level advisory board" to GRI's Board and Executive Management. ${ }^{119}$ As an informal body with no constitutional status, its role is to both enable GRI to understand better the governmental role in sustainability reporting, and for governments to learn about GRI. ${ }^{120}$ Individuals from government organizations, including "ministries and agencies with a direct interest in sustainability, CSR issues, and sustainability reporting" are invited to become members, with efforts made to recruit from both OECD and non-OECD countries. Current members include delegates from Brazil, India and South Africa. ${ }^{121}$

Beyond the governance structure of the $\mathrm{GRI}$, it is useful to note the scope of the Regional Network Program which: "raises awareness about sustainability reporting, shares and collects information, and meets local stakeholders - channelling their feedback into global projects and processes". ${ }^{122}$ "Focal points", part of regional networks, are national and regional GRI offices that "respond to local stakeholder needs, build sustainability reporting capacity and value, and encourage more regional stakeholders to participate in GRI's global network and

117 GRI, Technical Advisory Committee, available at: https://www.globalreporting. org/network/network-structure/technical-advisory-committee/Pages/default.aspx (last visited October 13, 2014).

118 GRI, Stakeholder Council, available at: https://www.globalreporting.org/ network/network-structure/stakeholder-council/Pages/default.aspx (last visited October 13, 2014).

${ }^{119} \mathrm{GRI}$, Governmental Advisory Group, available at: https://www.globalreporting. org/network/network-structure/governmental-advisory-group/Pages/default.aspx (last visited October 13, 2014).

120 GRI, Governmental Advisory Group, op. cit.

121 GRI, Governmental Advisory Group, op. cit.

122 GRI, Regional Networks, available at: https://www.globalreporting.org/ network/regional-networks/Pages/default.aspx (last visited October 13, 2014). 
activity". ${ }^{123}$ The GRI has "focal points" in Australia, Brazil, Canada, China, Colombia, India, South Africa and the United States. ${ }^{124}$

The GRI's Mining and Metals Sector Supplement (MMSS) was developed by a "multi-stakeholder, geographically diverse Working Group, formed by volunteers from the mining and metals sector, investors, labor, non-governmental organizations and research organizations," each participating in their individual capacity. ${ }^{125}$ A close examination of the list of working group participants reveals a very small number from emerging markets, including a Brazilian EM MNE and a South African labour union. ${ }^{126}$

The GRI is designed to apply without restrictions. Its aim is to provide organizational reporting guidance so that all companies and organizations can measure and report their sustainability performance. ${ }^{127}$ There is no geographic or country context limitation built into its application, nor into the reporting expectations identified in the MMSS. ${ }^{128}$

\subsection{OECD MNE Guidelines}

The OECD was formed in 1960 by 18 European countries, together with Canada and the United States. ${ }^{129}$ Fourteen countries

${ }^{123} \mathrm{GRI}$, Regional Networks, op. cit.

124 GRI, GRI Focal Points, available at: https://www.globalreporting.org/network/ regional-networks/gri-focal-points/Pages/default.asp x (last visited October 13, 2014).

125 GRI, Who Developed This Guidance and How? available at: https://www. globalreporting.org/reporting/sector-guidance/sector-guidance/mining-and-metals/ Pages/who-developed-this-guidance-and-how.aspx (last visited October 13, 2014).

${ }^{126} \mathrm{GRI}$, Who Developed This Guidance and How?, op. cit.

127 GRI, About GRI - A Sustainable Global Economy, available at: https://www. globalreporting.org/information/about-gri/Pages/default.aspx (last visited October 13, 2014).

128 GRI, G4 Sector Disclosures, Mining and Metals, op. cit. p. 7.

129 OECD, Members and partners, available at: http://www.oecd.org/about/ membersandpartners/ (last visited October 10, 2014). OECD, Convention on the Organisation for Economic Co-operation and Development (14 December 1960), available at: http://www.oecd.org/general/conventionontheorganisationforeconomic co-operationanddevelopment.htm (last visited October 13, 2014). 
have since become members of the OECD. ${ }^{130}$ Since 2007, the OECD has been actively working towards enhanced engagement with five key EM State partners: Brazil, China, India, Indonesia and South Africa. ${ }^{131}$ Indeed, according to a 2014 OECD Report, since the Council approved Guidelines in 2010 requesting Committees to review their Global Relations strategies, all committees have updated their strategies, "inviting these countries to attend Committee meetings and to be included in the Committees' products such as databases, country and regional reviews". ${ }^{132}$ Involving these key partners in the "full range of activities and instruments, with a view to possible future Membership, is a priority for the OECD" ${ }^{133}$ Other non-adhering States are invited to participate in the work of the OECD in different capacities, ranging from an invitation to accede to the OECD as a member, to the establishment of a country programme, to partnership in a particular OECD body. ${ }^{134}$

However, as of 2014, Brazil and Argentina are the only G20 EM economies that are so far engaged with the OECD Declaration on International Investment and Multinational Enterprises, of which the MNE Guidelines are a part, ${ }^{135}$ and both are non-OECD member adhering countries. ${ }^{136}$ As of 2014, twelve non-OECD countries adhere to the OECD MNE Guidelines. ${ }^{137}$ Together with the OECD's policy

130 For a list of Member countries and the dates on which they deposited their instruments of ratification, see List of OECD Member countries - Ratification of the Convention on the OECD, OECD, available at: http://www.oecd.org/general/ listofoecdmembercountries-ratificationoftheconventionontheoecd.htm (last visited October 13, 2014).

131 OECD, OECD Council Resolution on Enlargement and Enhanced Engagement, (May 16, 2007), available at: http://www.oecd.org/general/ oecdcouncilresolutiononenlargementandenhancedengagement.htm (last visited October 13, 2014). See also, OECD, The OECD's Relations with its Key Partners, available at: http://www.oecd.org/general/theoecdsrelationswithitskeypartners.htm (last visited October 13, 2014).

${ }^{132}$ OECD, Meeting of the OECD Council at Ministerial Level, Strengthening the OECD's Global Reach, (Paris, 6-7 May 2014), p.4, available at: http://www.oecd.org/ mcm/C-MIN(2014)11-ENG.pdf (last visited October 13, 2014); see also Guidelines C(2010)100/FINAL

${ }^{133}$ OECD, Strengthening the OECD's Global Reach, op. cit. p.5.

134 OECD, Strengthening the OECD's Global Reach, op. cit. p.43.

135 OECD, Strengthening the OECD's Global Reach, op. cit. p.49.

136 OECD Guidelines for MNEs, National Contact Points, available at: http:// mneguidelines.oecd.org/ncps/ (last visited October 13, 2014).

137 OECD Declaration and Decisions on International Investment and Multinational Enterprises, available at: http://www.oecd.org/corporate/mne/ oecddeclarationanddecisions.htm (last visited October 13, 2014). 
on enhanced engagement, this suggests that while the OECD MNE Guidelines were initially developed by developed State parties, they too are becoming more inclusive. Indeed, the process of updating the OECD MNE Guidelines that culminated in the 2011 revisions began with a consultation that included non-adhering States. ${ }^{138}$

Governments adhering to the OECD MNE Guidelines are committed "to continuous improvement of both domestic and international policies with a view to improving the welfare and living standards of all people". ${ }^{139}$ Moreover, adhering governments are to "encourage the enterprises operating on their territories to observe the Guidelines wherever they operate, while taking into account the particular circumstances of each host country". ${ }^{140}$

\section{Conclusions}

This paper has examined whether the international CSR frameworks referenced by the Canadian government in the extractive industries context would be legitimate choices for promotion by EM home countries to EM MNEs for implementation in their operations both domestically and internationally. If, as suggested in this paper, the measure of legitimacy may be assessed in accordance with the extent to which EM countries and EM MNEs participate in the governance and policy development of the institutions that promote and implement the CSR framework, then the answer differs with each individual standard. On this measure, the Voluntary Principles on Security and Human Rights appear to have been developed with very little input from EM countries or EM MNEs, although this may be changing due to global industry associations' promotion of the standard. On the other end of the spectrum, the GRI appears to have been developed with the

\footnotetext{
138 OECD, 2011 Update of the OECD Guidelines for Multinational Enterprises, available at: http://www.oecd.org/daf/inv/mne/2011update. htm (last visited October 8, 2014). The OECD describes this consultation as largely: "an open discussion of the perspectives of business, labour, NGOs, nonadhering countries and international organizations". OECD, Consultation on an update of the OECD Guidelines for Multinational Enterprises, (8 December 2009), available at: http://www.oecd.org/daf/inv/investmentfordevelopment/ consultationonanupdateoftheoecdguidelinesformultinationalenterprises.htm (last visited October 8, 2014).

${ }^{139}$ OECD MNE Guidelines, op. cit. p.15 para.9.

140 OECD MNE Guidelines, op. cit. p.17 para. 3.
} 
involvement of a diverse range of stakeholders and regions. The OECD has clearly developed its MNE Guidelines by and for OECD countries, yet, the Guidelines are adhered to by a small number of EM States, and the OECD is clearly eager to have greater engagement from, and possibly open membership to, other key EM countries. With regard to the IFC, while governance decisions are clearly weighted in the hands of developed countries and in particular the United States, EM countries do play a part in governance and have played a part in consultations over the content of the updated IFC Performance Standards.

A different but important question is, if an EM State were to require EM MNEs to comply with these standards, would compliance be limited to within other EM States, or be extended internationally? This is not an idol question, given the difference in approaches taken by the different standards. While the Voluntary Principles, GRI and OECD Guidelines contemplate application - at least in theory - to company operations wherever they take place in the world, the IFC Standards are designed to apply only within EM countries, due to the assumption that rich OECD countries have legislation that is at least as strong as the standards of the IFC. While this might generally be true, it is not guaranteed. Notably, the Canadian CSR Counsellor's mandate applied to operations internationally, although in practice issues were raised only with regard to operations in developing countries.

As noted above, each of the frameworks discussed here has embedded to some degree the business responsibility to respect human rights articulated in the UN Guiding Principles. The Guiding Principles also provide that States have a duty to protect human rights, and it is arguable that implementation of a preventative mechanism like the Canadian CSR counsellor could be viewed as a contribution to compliance with the State duty to protect. The CSR counsellor position has, of course, been much critiqued, as have many OECD National Contact Points that lack sufficiently robust institutional structures. Nevertheless, the idea that some kind of ombudsperson or similar mechanism with a mandate to measure compliance by home State MNEs with international standards is frequently suggested, though rarely implemented satisfactorily. As I have documented elsewhere, the reluctance of the Canadian State to make such a requirement legally binding in any way is hinged largely on concerns that such a requirement would create a competitive disadvantage for Canadian 
firms operating in the extractive sector. ${ }^{141}$ This paper's contribution is to evaluate the extent to which the frameworks promoted by Canada could also be adopted by EM States that have extensive EM MNEs operating in resource extraction.

Ultimately, home State regulation is clearly one important tool to address human rights concerns arising from MNE operations in global mining. Moreover, when an MNE is also a State-owned enterprise (SOE), the argument that the home State is under an obligation to prevent and remedy any human rights violations associated with it anywhere in the world is clearly stronger. ${ }^{142}$ The need for the global governance gap to be filled is clear, perhaps especially with regard to access to remedy. Indeed, critiques of the Guiding Principles observe that despite the alleged consensus at the United Nations Human Rights Council, advocacy groups and many Third World States remain deeply concerned that the Guiding Principles are overly reliant upon voluntary action by business, and fail to provide effective mechanisms for legal accountability of businesses to victims. This concern led to a resolution tabled in June 2014 at the UN Human Rights Council by Ecuador (with Bolivia, Cuba, South Africa and the Bolivarian Republic of Venezuela) proposing an international legally binding instrument on transnational corporations and human rights. Though subsequently passed by the Council, all Western State members of the Council voted against the resolution, while China, India, the Russian Federation and most developing nations voted in favour. ${ }^{143}$ Moving forward, an intergovernmental working group with a mandate to elaborate such an instrument will be established. Yet, as evident from the process that led to the development of a global consensus on anti-corruption, including eventually both an OECD Convention and a UN Treaty, a first necessary step is evidence of State practice in conformity with

${ }^{141}$ Seck (2011).

142 UN Guiding Principles, op. cit. p.9.

${ }^{143}$ Business and Human Rights Resource Centre, "Binding treaty: UN Human Rights Council sessions," available at: http://business-humanrights.org/en/binding-treaty/unhuman-rights-council-sessions (last visited October 14, 2014). There were 20 votes in favour, 14 against, and 13 abstentions. This resolution has been criticized for failing to encompass all business enterprises, rather than just TNCs. A parallel resolution put forward by Norway asks the Working Group on Business and Human Rights, charged in 2011 with implementation the Guiding Principles, to consider both the benefits and limitations of legally binding instruments. 
the treaty objectives. ${ }^{144}$ This is a step that Canada has so far struggled unsuccessfully to take. This paper offers insights into one possible route that other countries, whether rich or EM States, might adopt to move this agenda forward.

\section{References}

Brown, Halina Szejnwald (2011). "Global Reporting Initiative", in Thomas Hale and David Held (eds.), Transnational Governance, Institutions and Innovations (Cambridge, UK: Polity Press).

Chimni, B.S. (2012). "Capitalism, Imperialism, and International Law in the Twenty-First Century", Oregon Review of International Law, 14: 17-46.

Keller, Helen (2008). "Codes of Conduct and their Implementation: the Question of Legitimacy", in Rüdiger Wolfrum and Volker Röben (eds.), Legitimacy in International Law (Berlin: Springer).

Morgera, Elisa (2009). Corporate Accountability in International Environmental Law. (Oxford: Oxford University Press).

OECD (2011). OECD Guidelines for Multinational Enterprises (Paris: OECD).

Seck, Sara L. (2008a). "Home State Responsibility and Local Communities: the Case of Global Mining", Yale Human Rights \& Development Law Journal, 11: 177-206; Reprinted in C. Sri Krishna, ed., Global Mining Experiences (Amicus Books, Icfai Press, India, 2009).

Seck, Sara L. (2008b). "Unilateral Home State Regulation: Imperialism or Tool for Subaltern Resistance?", Osgoode Hall Law Journal, 46: 565.

Seck, Sara L. (2010). "Conceptualizing the Home State Duty to Protect Human Rights" in Karin Buhmann, Lynn Roseberry, \& Mette Morsing (eds.), Corporate Social and Human Rights Responsibilities: Global Legal and Management Perspectives. (Basingstoke: Palgrave Macmillan).

Seck, Sara L. (2011). "Canadian Mining Internationally and the UN Guiding Principles for Business and Human Rights", Canadian Yearbook of International Law, 49: 51-116.

Seck, Sara L. (2012). "Home State Regulation of Environmental Human Rights Harms as Transnational Private Regulatory Governance", German Law Journal, 13: 13631385.

Simons, Penelope, and Audrey Macklin (2014). The Governance Gap: Extractive Industries, Human Rights, and the Home State Advantage. (London: Routledge).

144 Seck (2008b), noting role of US FCPA as driving agenda. 